Cochrane Database of Systematic Reviews

\title{
Primaquine alternative dosing schedules for preventing malaria relapse in people with Plasmodium vivax (Review)
}

Milligan R, Daher A, Villanueva G, Bergman H, Graves PM

Milligan R, Daher A, Villanueva G, Bergman H, Graves PM.

Primaquine alternative dosing schedules for preventing malaria relapse in people with Plasmodium vivax.

Cochrane Database of Systematic Reviews 2020, Issue 8. Art. No.: CD012656.

DOI: 10.1002/14651858.CD012656.pub3.

www.cochranelibrary.com

Primaquine alternative dosing schedules for preventing malaria relapse in people with Plasmodium vivax (Review) 
TABLE OF CONTENTS

HEADER

ABSTRACT

PLAIN LANGUAGE SUMMARY

SUMMARY OF FINDINGS

BACKGROUND

OBJECTIVES

METHODS

RESULTS

Figure 1.

Figure 2.

DISCUSSION

AUTHORS' CONCLUSIONS

ACKNOWLEDGEMENTS

REFERENCES

CHARACTERISTICS OF STUDIES

DATA AND ANALYSES

Analysis 1.1. Comparison 1: $0.5 \mathrm{mg} / \mathrm{kg} /$ day 7 days versus standard $0.25 \mathrm{mg} / \mathrm{kg} /$ day 14 days, Outcome 1: Recurrence by 6 to 7 months' follow-up

Analysis 1.2. Comparison 1: $0.5 \mathrm{mg} / \mathrm{kg} /$ day 7 days versus standard $0.25 \mathrm{mg} / \mathrm{kg} /$ day 14 days, Outcome 2: Recurrence by 6 to 7 months' follow-up (PCR-adjusted)

Analysis 1.3. Comparison 1: $0.5 \mathrm{mg} / \mathrm{kg} /$ day 7 days versus standard $0.25 \mathrm{mg} / \mathrm{kg} /$ day 14 days, Outcome 3: Recurrence by 6 to 7 months subgrouped by geographical region

Analysis 1.4. Comparison 1: $0.5 \mathrm{mg} / \mathrm{kg} /$ day 7 days versus standard $0.25 \mathrm{mg} / \mathrm{kg} /$ day 14 days, Outcome 4: Recurrence by 6 to 7 months subgrouped by directly observed therapy (DOT) versus non-DOT

Analysis 1.5 . Comparison 1: $0.5 \mathrm{mg} / \mathrm{kg} /$ day 7 days versus standard $0.25 \mathrm{mg} / \mathrm{kg} /$ day 14 days, Outcome 5: Serious adverse events

Analysis 1.6. Comparison 1: $0.5 \mathrm{mg} / \mathrm{kg} /$ day 7 days versus standard $0.25 \mathrm{mg} / \mathrm{kg} /$ day 14 days, Outcome 6: Adverse events that result in discontinuation of treatment

Analysis 1.7. Comparison 1: $0.5 \mathrm{mg} / \mathrm{kg} /$ day 7 days versus standard $0.25 \mathrm{mg} / \mathrm{kg} /$ day 14 days, Outcome 7 : Adverse events during chloroquine administration

Analysis 1.8. Comparison 1: $0.5 \mathrm{mg} / \mathrm{kg} /$ day 7 days versus standard $0.25 \mathrm{mg} / \mathrm{kg} /$ day 14 days, Outcome 8: Adverse effects during primaquine administration

Analysis 1.9. Comparison $1: 0.5 \mathrm{mg} / \mathrm{kg} /$ day 7 days versus standard $0.25 \mathrm{mg} / \mathrm{kg} /$ day 14 days, Outcome 9: Other adverse events . Analysis 1.10 . Comparison 1: $0.5 \mathrm{mg} / \mathrm{kg} /$ day 7 days versus standard $0.25 \mathrm{mg} / \mathrm{kg} /$ day 14 days, Outcome 10: Anaemia or change in haemoglobin status

Analysis 2.1. Comparison 2: High-standard $0.5 \mathrm{mg} / \mathrm{kg} /$ day 14 days versus standard $0.25 \mathrm{mg} / \mathrm{kg} /$ day 14 days, Outcome 1 : Recurrence by 6 months' follow-up

Analysis 2.2. Comparison 2: High-standard $0.5 \mathrm{mg} / \mathrm{kg} /$ day 14 days versus standard $0.25 \mathrm{mg} / \mathrm{kg} /$ day 14 days, Outcome 2 : Recurrence by 6 months' follow-up (PCR-adjusted)

Analysis 2.3. Comparison 2: High-standard $0.5 \mathrm{mg} / \mathrm{kg} /$ day 14 days versus standard $0.25 \mathrm{mg} / \mathrm{kg} /$ day 14 days, Outcome 3: Serious adverse events

Analysis 2.4. Comparison 2: High-standard $0.5 \mathrm{mg} / \mathrm{kg} /$ day 14 days versus standard $0.25 \mathrm{mg} / \mathrm{kg} /$ day 14 days, Outcome 4: Adverse events that result in discontinuation of treatment

Analysis 2.5. Comparison 2: High-standard $0.5 \mathrm{mg} / \mathrm{kg} /$ day 14 days versus standard $0.25 \mathrm{mg} / \mathrm{kg} /$ day 14 days, Outcome 5: Other adverse events

Analysis 3.1. Comparison 3: $0.75 \mathrm{mg} / \mathrm{kg} /$ week 8 weeks versus high-standard $0.5 \mathrm{mg} / \mathrm{kg} /$ day 14 days, Outcome 1: Recurrence .. Analysis 3.2. Comparison 3: $0.75 \mathrm{mg} / \mathrm{kg} /$ week 8 weeks versus high-standard $0.5 \mathrm{mg} / \mathrm{kg} /$ day 14 days, Outcome 2: Serious adverse events

Analysis 3.3. Comparison 3: $0.75 \mathrm{mg} / \mathrm{kg} /$ week 8 weeks versus high-standard $0.5 \mathrm{mg} / \mathrm{kg} / \mathrm{day} 14$ days, Outcome 3: Anaemia (haemoglobin $<7 \mathrm{~g} / \mathrm{dL}$ )

Analysis 3.4. Comparison 3: $0.75 \mathrm{mg} / \mathrm{kg} /$ week 8 weeks versus high-standard $0.5 \mathrm{mg} / \mathrm{kg} /$ day 14 days, Outcome 4: Other adverse events

Analysis 4.1. Comparison 4: $1.0 \mathrm{mg} / \mathrm{kg} /$ day primaquine 7 days versus high-standard $0.5 \mathrm{mg} / \mathrm{kg} / \mathrm{day} 14$ days, Outcome 1 : Recurrence by 12 months' follow-up 
Analysis 4.2. Comparison 4: $1.0 \mathrm{mg} / \mathrm{kg} /$ day primaquine 7 days versus high-standard $0.5 \mathrm{mg} / \mathrm{kg} / \mathrm{day} 14$ days, Outcome 2 : Recurrence by 12 months' follow-up subgrouped by geographical region

Analysis 4.3. Comparison 4: $1.0 \mathrm{mg} / \mathrm{kg} /$ day primaquine 7 days versus high-standard $0.5 \mathrm{mg} / \mathrm{kg} /$ day 14 days, Outcome 3 : Recurrence by 6 months' follow-up

Analysis 4.4. Comparison 4: $1.0 \mathrm{mg} / \mathrm{kg} /$ day primaquine 7 days versus high-standard $0.5 \mathrm{mg} / \mathrm{kg} /$ day 14 days, Outcome 4 : Recurrence by 3 months' follow-up

Analysis 4.5. Comparison 4: $1.0 \mathrm{mg} / \mathrm{kg} /$ day primaquine 7 days versus high-standard $0.5 \mathrm{mg} / \mathrm{kg} /$ day 14 days, Outcome 5: P vivax parasitaemia

Analysis 4.6. Comparison 4: $1.0 \mathrm{mg} / \mathrm{kg} /$ day primaquine 7 days versus high-standard $0.5 \mathrm{mg} / \mathrm{kg} /$ day 14 days, Outcome 6: Serious adverse events

Analysis 4.7. Comparison 4: $1.0 \mathrm{mg} / \mathrm{kg} /$ day primaquine 7 days versus high-standard $0.5 \mathrm{mg} / \mathrm{kg} /$ day 14 days, Outcome 7: Adverse events that resulted in discontinuation of treatment

Analysis 4.8. Comparison 4: $1.0 \mathrm{mg} / \mathrm{kg} /$ day primaquine 7 days versus high-standard $0.5 \mathrm{mg} / \mathrm{kg} / \mathrm{day} 14$ days, Outcome 8: Other adverse events

Analysis 4.9. Comparison 4: $1.0 \mathrm{mg} / \mathrm{kg} /$ day primaquine 7 days versus high-standard $0.5 \mathrm{mg} / \mathrm{kg} / \mathrm{day} 14$ days, Outcome 9 : Anaemia

Analysis 5.1. Comparison 5: $0.375 \mathrm{mg} / \mathrm{kg} /$ day primaquine for 14 days versus standard 14-day regimen, Outcome 1: Recurrence by 6 months' follow-up

Analysis 6.1. Comparison 6: $1.17 \mathrm{mg} / \mathrm{kg} /$ day primaquine for 3 days versus standard 14-day regimen, Outcome 1: Recurrence by 4 months' follow-up

ADDITIONAL TABLES

APPENDICES

WHAT'S NEW

HISTORY

CONTRIBUTIONS OF AUTHORS

DECLARATIONS OF INTEREST

SOURCES OF SUPPORT

DIFFERENCES BETWEEN PROTOCOL AND REVIEW 
[Intervention Review]

\section{Primaquine alternative dosing schedules for preventing malaria relapse in people with Plasmodium vivax}

Rachael Milligan¹, André Daher2,3, Gemma Villanueva4, Hanna Bergman4, Patricia M Graves 5

1Cochrane Infectious Diseases Group, Liverpool School of Tropical Medicine, Liverpool, UK. 2Vice-Presidency of Research and Biological Collections, Oswaldo Cruz Foundation (FIOCRUZ), Rio de Janeiro, Brazil. ${ }^{3}$ Department of Clinical Sciences, Liverpool School of Tropical Medicine, Liverpool, UK. ${ }^{4}$ Cochrane Response, Cochrane, London, UK. ${ }^{5}$ College of Public Health, Medical and Veterinary Sciences, James Cook University, Cairns, Australia

Contact address: Rachael Milligan, Rachael.Milligan@lstmed.ac.uk.

Editorial group: Cochrane Infectious Diseases Group.

Publication status and date: New search for studies and content updated (conclusions changed), published in Issue 8, 2020.

Citation: Milligan R, Daher A, Villanueva G, Bergman H, Graves PM. Primaquine alternative dosing schedules for preventing malaria relapse in people with Plasmodium vivax. Cochrane Database of Systematic Reviews 2020, Issue 8. Art. No.: CD012656. DOI: 10.1002/14651858.CD012656.pub3.

Copyright (c) 2020 The Authors. Cochrane Database of Systematic Reviews published by John Wiley \& Sons, Ltd. on behalf of The Cochrane Collaboration. This is an open access article under the terms of the Creative Commons Attribution-Non-Commercial Licence, which permits use, distribution and reproduction in any medium, provided the original work is properly cited and is not used for commercial purposes.

\section{A B S T R A C T}

\section{Background}

Plasmodium vivax liver stages (hypnozoites) may cause relapses, prolonging morbidity, and impeding malaria control and elimination. The World Health Organization (WHO) recommends three schedules for primaquine: $0.25 \mathrm{mg} / \mathrm{kg} / \mathrm{day}$ (standard), or $0.5 \mathrm{mg} / \mathrm{kg} / \mathrm{day}$ (high standard) for 14 days, or $0.75 \mathrm{mg} / \mathrm{kg}$ once weekly for eight weeks, all of which can be difficult to complete. Since primaquine can cause haemolysis in individuals with glucose-6-phosphate dehydrogenase (G6PD) deficiency, clinicians may be reluctant to prescribe primaquine without G6PD testing, and recommendations when G6PD status is unknown must be based on an assessment of the risks and benefits of prescribing primaquine. Alternative safe and efficacious regimens are needed.

\section{Objectives}

To assess the efficacy and safety of alternative primaquine regimens for radical cure of $P$ vivax malaria compared to the standard or highstandard 14-day courses.

\section{Search methods}

We searched the Cochrane Infectious Diseases Group Specialized Register; the Cochrane Central Register of Controlled Trials (CENTRAL); MEDLINE (PubMed); Embase (Ovid); LILACS (BIREME); WHO International Clinical Trials Registry Platform and ClinicalTrials.gov up to 2 September 2019, and checked the reference lists of all identified studies.

\section{Selection criteria}

Randomized controlled trials (RCTs) of adults and children with $P$ vivax malaria using either chloroquine or artemisinin-based combination therapy plus primaquine at a total adult dose of at least $210 \mathrm{mg}$, compared with the WHO-recommended regimens of $0.25 \mathrm{or} 0.5 \mathrm{mg} / \mathrm{kg} /$ day for 14 days. 


\section{Data collection and analysis}

Two review authors independently assessed trial eligibility and quality, and extracted data. We calculated risk ratios (RRs) with 95\% confidence intervals (Cls) for dichotomous data. We grouped efficacy data according to length of follow-up, partner drug, and trial location. We analysed safety data where included.

\section{Main results}

\section{$0.5 \mathrm{mg} / \mathrm{kg} /$ day for seven days versus standard $0.25 \mathrm{mg} / \mathrm{kg} /$ day for 14 days}

There may be little or no difference in $P$ vivax recurrences at six to seven months when using the same total dose (210 mg adult dose) over seven days compared to 14 days (RR $0.96,95 \% \mathrm{Cl} 0.66$ to $1.39 ; 4 \mathrm{RCTs}, 1211$ participants; low-certainty evidence). No serious adverse events were reported. We do not know if there is any difference in the number of adverse events resulting in discontinuation of primaquine (RR $1.04,95 \% \mathrm{Cl} 0.15$ to $7.38 ; 5 \mathrm{RCTs}, 1427$ participants) or in the frequency of anaemia (RR 3.00, 95\% $\mathrm{Cl} 0.12$ to $72.91,1 \mathrm{RCT}, 240$ participants) between the shorter and longer regimens (very low-certainty evidence). Three trials excluded people with G6PD deficiency; two did not provide this information. Pregnant and lactating women were either excluded or no details were provided.

\section{High-standard $0.5 \mathrm{mg} / \mathrm{kg} /$ day for 14 days versus standard $0.25 \mathrm{mg} / \mathrm{kg} /$ day for 14 days}

There may be little or no difference in $P$ vivax recurrences at six months with $0.5 \mathrm{mg} / \mathrm{kg} /$ day primaquine for 14 days compared to $0.25 \mathrm{mg} /$ $\mathrm{kg} /$ day for 14 days (RR 0.84 (95\% Cl 0.49 to 1.43; 2 RCTs, 677 participants, low-certainty evidence). No serious adverse events were reported. We do not know whether there is a difference in adverse events resulting in discontinuation of treatment with the high-standard dosage (RR 4.19, 95\% Cl 0.90 to 19.60; 1 RCT, 778 participants, very low-certainty evidence). People with G6PD deficiency and pregnant or lactating women were excluded.

\section{$0.75 \mathrm{mg} / \mathrm{kg} /$ week for eight weeks versus high-standard $0.5 \mathrm{mg} / \mathrm{kg} /$ day for 14 days}

We do not know whether weekly primaquine increases or decreases recurrences of $P$ vivax compared to high-standard $0.5 \mathrm{mg} / \mathrm{kg} / \mathrm{day}$ for 14 days, at 11 months' follow-up (RR 3.18, 95\% Cl 0.37 to 27.60; 1 RCT, 122 participants; very low-certainty evidence). No serious adverse events and no episodes of anaemia were reported. G6PD-deficient patients were not randomized but included in the weekly primaquine group (only one patient detected).

\section{$1 \mathrm{mg} / \mathrm{kg} /$ day for seven days versus high standard $0.5 \mathrm{mg} / \mathrm{kg} /$ day for 14 days}

There is probably little or no difference in $P$ vivax recurrences at 12 months between $1.0 \mathrm{mg} / \mathrm{kg} /$ day primaquine for seven days and the high-standard $0.5 \mathrm{mg} / \mathrm{kg} /$ day for 14 days (RR 1.03, 95\% Cl 0.82 to 1.30; 2 RCTs, 2526 participants; moderate-certainty evidence). There may be moderate to large increase in serious adverse events in the $1.0 \mathrm{mg} / \mathrm{kg} /$ day primaquine for seven days compared with the high-standard $0.5 \mathrm{mg} / \mathrm{kg} /$ day for 14 days, during 42 days follow-up (RR $12.03,95 \% \mathrm{Cl} 1.57$ to $92.30 ; 1 \mathrm{RCT}, 1872$ participants, low-certainty evidence). We do not know if there is a difference between $1.0 \mathrm{mg} / \mathrm{kg} /$ day primaquine for seven days and high-standard $0.5 \mathrm{mg} / \mathrm{kg} / \mathrm{day}$ for $14 \mathrm{days}$ in adverse events that resulted in discontinuation of treatment (RR 2.50, 95\% Cl 0.49 to $12.87 ; 1 \mathrm{RCT}, 2526$ participants, very low-certainty evidence), nor if there is difference in frequency of anaemia by 42 days (RR $0.93,95 \% \mathrm{Cl} 0.62$ to $1.41 ; 2$ RCTs, 2440 participants, very lowcertainty evidence). People with G6PD deficiency were excluded.

\section{Other regimens}

Two RCTs evaluated other rarely-used doses of primaquine, one of which had very high loss to follow-up. Adverse events were not reported. People with G6PD deficiency and pregnant or lactating women were excluded.

\section{Authors' conclusions}

Trials available to date do not detect a difference in recurrence between the following regimens: 1) $0.5 \mathrm{mg} / \mathrm{kg} / \mathrm{day}$ for seven days versus standard $0.25 \mathrm{mg} / \mathrm{kg} /$ day for 14 days; 2) high-standard $0.5 \mathrm{mg} / \mathrm{kg} /$ day for 14 days versus standard $0.25 \mathrm{mg} / \mathrm{kg} / \mathrm{day}$ for $14 \mathrm{days} ; 3) 0.75 \mathrm{mg} /$ $\mathrm{kg} /$ week for eight weeks versus high-standard $0.5 \mathrm{mg} / \mathrm{kg} /$ day for 14 days; 4) $1 \mathrm{mg} / \mathrm{kg} /$ day for seven days versus high-standard $0.5 \mathrm{mg} / \mathrm{kg} /$ day for 14 days. There were no differences detected in adverse events for Comparisons 1,2 or 3 , but there may be more serious adverse events with the high seven-day course in Comparison 4.

The shorter regimen of $0.5 \mathrm{mg} / \mathrm{kg} /$ day for seven days versus standard $0.25 \mathrm{mg} / \mathrm{kg} /$ day for 14 days may suit G6PD-normal patients. Further research will help increase the certainty of the findings and applicability in different settings.

\section{PLAIN LANGUAGE SUMMARY}

\section{Primaquine to cure people with Plasmodium vivax malaria: comparing dosing schedules}

Plasmodium vivax malaria can sometimes cause potentially life-threatening illness, and the infection continues to make many people unwell. The infection includes a liver stage, and this requires primaquine to eradicate it and prevent the infection recurring. However, the current dosing schedule requires 14 days of daily treatment. 


\section{What are the concerns about primaquine?}

Primaquine is the only drug currently recommended to treat the liver parasites in $P$ vivax malaria. It can cause anaemia in people with glucose-6-phosphate dehydrogenase (G6PD) deficiency, which is a relatively common genetic blood disorder. Shorter regimens would help reduce the risk of default with the current two-week regimen.

\section{What does the research say?}

We summarized trials that compared the World Health Organization (WHO)-recommended primaquine regimen of $15 \mathrm{mg}$ to $30 \mathrm{mg}$ per day for 14 days with the same $(210 \mathrm{mg})$ or higher total doses of primaquine given over different lengths of time to determine whether alternative regimens were as successful as the recommended courses at preventing future episodes of $P$ vivax malaria. We searched for trials up to 2 September 2019 and included 11 randomized controlled trials (RCTs) (studies in which participants are assigned to one of two or more treatment groups in a random manner) in our analysis.

When using $30 \mathrm{mg}$ primaquine per day for seven days compared to $15 \mathrm{mg}$ per day for 14 days, there may be little or no difference in $P$ vivax recurrences at six to seven months (low-certainty evidence). No serious adverse events were reported. We do not know if there is a difference in the number of adverse events that cause people to stop taking the drug (low-certainty evidence).

When using $30 \mathrm{mg}$ per day compared to $15 \mathrm{mg}$ per day primaquine therapy for 14 days, we do not know if there is any difference in $P$ vivax recurrences at six months (very low-certainty evidence). No serious adverse events were reported, but it is unclear whether or not there is a difference between doses in other adverse events that cause people to stop taking the drug (very low-certainty evidence).

We do not know whether primaquine at $45 \mathrm{mg}$ once per week for eight weeks increases or decreases recurrences of $P$ vivax compared to the high standard $30 \mathrm{mg}$ per day for 14-days, at 11 months' follow-up (very low-certainty evidence).

There is probably little or no difference for recurrence using high dose $60 \mathrm{mg}$ per day for seven days compared to the high standard $30 \mathrm{mg}$ per day for 14 days, but there may be an increase in serious adverse events in the high-dose shorter course regimen group.

Further RCTs will help improve the certainty of the evidence around alternative regimens,

\section{How up-to-date is this review?}

The review authors searched for studies up to 2 September 2019. 


\section{SUMMARY OF FINDINGS}

\section{Summary of findings 1 . Summary of findings table 1 (main comparison)}

$0.5 \mathrm{mg} / \mathrm{kg}$ primaquine/day for 7 days versus standard $0.25 \mathrm{mg} / \mathrm{kg} /$ day for 14 days for radical cure of $P$ vivax malaria

Patient or population: adults and children with confirmed clinical and parasitological $P$ vivax malaria

Setting: India, Peru, Brazil

Intervention: $0.5 \mathrm{mg} / \mathrm{kg} /$ day primaquine for 7 days (adult dose $30 \mathrm{mg} /$ day, total dose $210 \mathrm{mg}$ )

Comparison: standard 14-day course primaquine $(0.25 \mathrm{mg} / \mathrm{kg} /$ day, adult dose $15 \mathrm{mg} /$ day; total dose $210 \mathrm{mg})$

\begin{tabular}{|c|c|c|c|c|c|c|}
\hline \multirow[t]{2}{*}{ Outcomes } & \multicolumn{2}{|c|}{ Anticipated absolute effects ${ }^{\star}(95 \% \mathrm{Cl})$} & \multirow{2}{*}{$\begin{array}{l}\text { Relative } \\
\text { effect } \\
(95 \% \mathrm{CI})\end{array}$} & \multirow{2}{*}{$\begin{array}{l}\text { № of } \\
\text { partici- } \\
\text { pants } \\
\text { (trials) }\end{array}$} & \multirow{2}{*}{$\begin{array}{l}\text { Certainty of the evi- } \\
\text { dence } \\
\text { (GRADE) }\end{array}$} & \multirow[t]{2}{*}{ Comments } \\
\hline & $\begin{array}{l}\text { Risk with stan- } \\
\text { dard 14-day } \\
\text { course pri- } \\
\text { maquine }\end{array}$ & $\begin{array}{l}\text { Risk with } 0.5 \mathrm{mg} / \mathrm{kg} / \\
\text { day primaquine for } \\
7 \text { days }\end{array}$ & & & & \\
\hline $\begin{array}{l}\text { Recurrence of } P \text { vivax } \\
\text { parasitaemia } \\
\text { Follow-up: range } 6 \\
\text { months to } 7 \text { months }\end{array}$ & 84 per 1000 & $\begin{array}{l}81 \text { per } 1000 \\
(55 \text { to } 117)\end{array}$ & $\begin{array}{l}\text { RR } 0.96 \\
(0.66 \text { to } \\
1.39)\end{array}$ & $\begin{array}{l}1211 \\
\text { (4 RCTs) }\end{array}$ & $\begin{array}{l}\oplus \oplus \ominus \ominus \\
\text { LOWa,b } \\
\text { due to risk of bias and } \\
\text { imprecision }\end{array}$ & $\begin{array}{l}\text { There may be little or no difference be- } \\
\text { tween } 0.5 \mathrm{mg} / \mathrm{kg} / \text { day primaquine for } 7 \text { days } \\
\text { and the standard } 14 \text {-day course. }\end{array}$ \\
\hline Serious adverse events & $\begin{array}{l}\text { Not estimable ( } 0 \\
\text { events in } 723 \text { par- } \\
\text { ticipants) }\end{array}$ & $\begin{array}{l}\text { Not estimable ( } 0 \\
\text { events in } 704 \text { partici- } \\
\text { pants) }\end{array}$ & $\begin{array}{l}\text { Not es- } \\
\text { timable }\end{array}$ & $\begin{array}{l}1427 \\
\text { (5 RCTs) }\end{array}$ & - & No events reported. \\
\hline $\begin{array}{l}\text { Adverse events that re- } \\
\text { sult in the discontinua- } \\
\text { tion of treatment }\end{array}$ & 3 per 1000 & $\begin{array}{l}3 \text { per } 1000 \\
(0 \text { to } 20)\end{array}$ & $\begin{array}{l}\text { RR } 1.04 \\
(0.15 \text { to } \\
7.38)\end{array}$ & $\begin{array}{l}1427 \\
\text { (5 RCTs) }\end{array}$ & $\begin{array}{l}\oplus \odot \ominus \ominus \\
\text { VERY LOWc,d } \\
\text { due to risk of bias and } \\
\text { serious imprecision }\end{array}$ & $\begin{array}{l}\text { We do not know if there is any difference in } \\
\text { adverse events that result in treatment dis- } \\
\text { continuation between } 0.5 \mathrm{mg} / \mathrm{kg} / \text { day pri- } \\
\text { maquine for } 7 \text { days and the standard 14-day } \\
\text { course. }\end{array}$ \\
\hline $\begin{array}{l}\text { Anaemia or change in } \\
\text { haemoglobin status }\end{array}$ & $\begin{array}{l}\text { Not estimable ( } 0 \\
\text { events in } 120 \text { par- } \\
\text { ticipants) }\end{array}$ & $\begin{array}{l}\text { Not estimable }(1 \\
\text { event in } 120 \text { partici- } \\
\text { pants) }\end{array}$ & $\begin{array}{l}\text { RR } 3.0 \\
(0.12 \text { to } \\
72.91)\end{array}$ & $\begin{array}{l}240 \\
(1 \mathrm{RCT})\end{array}$ & $\begin{array}{l}\oplus \ominus \ominus \ominus \\
\text { VERY LOWe,f,g } \\
\text { due to risk of bias, indi- } \\
\text { rectness, and serious im- } \\
\text { precision }\end{array}$ & $\begin{array}{l}\text { We do not know if the occurrence of } \\
\text { anaemia differs between the } 2 \text { treatment } \\
\text { regimens. }\end{array}$ \\
\hline
\end{tabular}

${ }^{\star}$ The risk in the intervention group (and its $95 \% \mathrm{Cl}$ ) is based on the assumed risk in the comparison group and the relative effect of the intervention (and its $95 \% \mathrm{Cl}$ ).

Abbreviations: Cl: confidence interval; RCT: randomized controlled trial; RR: risk ratio. 
GRADE Working Group grades of evidence

High certainty: we are very confident that the true effect lies close to that of the estimate of the effect.

Moderate certainty: we are moderately confident in the effect estimate: the true effect is likely to be close to the estimate of the effect, but there is a possibility that it is

substantially different.

Low certainty: our confidence in the effect estimate is limited: the true effect may be substantially different from the estimate of the effect.

Very low certainty: we have very little confidence in the effect estimate: the true effect is likely to be substantially different from the estimate of effect.

aDowngraded once for risk of bias: Rajgor 2014 IND, which contributed the most weight to the meta-analysis, was at high risk of selection bias due to no allocation concealment and high risk of attrition bias. Although Pareek 2015 IND was at risk of selection bias as well as other bias for being funded and carried out by drug company, it only contributed a small amount of weight to the meta-analysis.

bDowngraded once for imprecision: wide Cls - may be 34\% reduction in malaria recurrences or $40 \%$ increase with $0.5 \mathrm{mg} / \mathrm{kg} / \mathrm{day}$ primaquine for seven days.

cDowngraded once for risk of bias: Rajgor 2014 IND was at high risk of selection bias due to no allocation concealment and high risk of attrition bias. Pareek 2015 IND was at risk of selection bias as well as other bias for being funded and carried out by drug company.

dDowngraded twice for serious imprecision: very few events (only four events occurring in one trial, Rajgor 2014 IND), very wide Cls.

eDowngraded once due to risk of bias: Pareek 2015 IND was at risk of selection bias and other bias (funded and performed by drug company).

fDowngraded once for indirectness: only one study that excluded G6PD-deficient adults measured this safety outcome (Pareek 2015 IND).

gDowngraded twice for serious imprecision: only one event (in the $0.5 \mathrm{mg} / \mathrm{kg} /$ day primaquine for seven days group), very wide Cls.

\section{Summary of findings 2 . Summary of findings table 2}

\section{High standard $0.5 \mathrm{mg} / \mathrm{kg}$ primaquine /day for 14 days versus standard $0.25 \mathrm{mg} / \mathrm{kg} /$ day for 14 days for radical cure of $P$ vivax malaria}

Patient or population: adults and children with confirmed clinical and parasitological $P$ vivax malaria

Setting: India

Intervention: high-standard 14-day course primaquine $(0.5 \mathrm{mg} / \mathrm{kg} /$ day, adult dose $30 \mathrm{mg} /$ day; total dose $420 \mathrm{mg})$

Comparison: standard 14-day course primaquine $(0.25 \mathrm{mg} / \mathrm{kg} /$ day, adult dose $15 \mathrm{mg} /$ day; total dose $210 \mathrm{mg}$ )

\begin{tabular}{|c|c|c|c|c|c|c|}
\hline \multirow[t]{2}{*}{ Outcomes } & \multicolumn{2}{|c|}{ Anticipated absolute effects* $(95 \% \mathrm{Cl})$} & \multirow{2}{*}{$\begin{array}{l}\text { Relative } \\
\text { effect } \\
(95 \% \mathrm{CI})\end{array}$} & \multirow{2}{*}{$\begin{array}{l}\text { № of } \\
\text { partici- } \\
\text { pants } \\
\text { (trials) }\end{array}$} & \multirow{2}{*}{$\begin{array}{l}\text { Certainty of the evi- } \\
\text { dence } \\
\text { (GRADE) }\end{array}$} & \multirow[t]{2}{*}{ Comments } \\
\hline & $\begin{array}{l}\text { Risk with stan- } \\
\text { dard 14-day } \\
\text { course pri- } \\
\text { maquine }\end{array}$ & $\begin{array}{l}\text { Risk with high-stan- } \\
\text { dard 14-day course } \\
\text { primaquine }\end{array}$ & & & & \\
\hline $\begin{array}{l}\text { Recurrence of } P \text { vivax } \\
\text { parasitaemia } \\
\text { follow-up: range } 6 \\
\text { months to } 7 \text { months }\end{array}$ & 82 per 1000 & $\begin{array}{l}69 \text { per } 1000 \\
(40 \text { to } 117)\end{array}$ & $\begin{array}{l}\text { RR } 0.84 \\
(0.49 \text { to } \\
1.43)\end{array}$ & $\begin{array}{l}677 \\
\text { (2 RCTs) }\end{array}$ & $\begin{array}{l}\oplus \oplus \Theta \ominus \\
\text { LOWa,b } \\
\text { due to risk of bias } \\
\text { and imprecision }\end{array}$ & $\begin{array}{l}\text { There may be little or no difference in } P \text { vivax re- } \\
\text { currences between high-standard or standard } \\
\text { 14-day courses of primaquine given with chloro- } \\
\text { quine or an ACT. }\end{array}$ \\
\hline
\end{tabular}




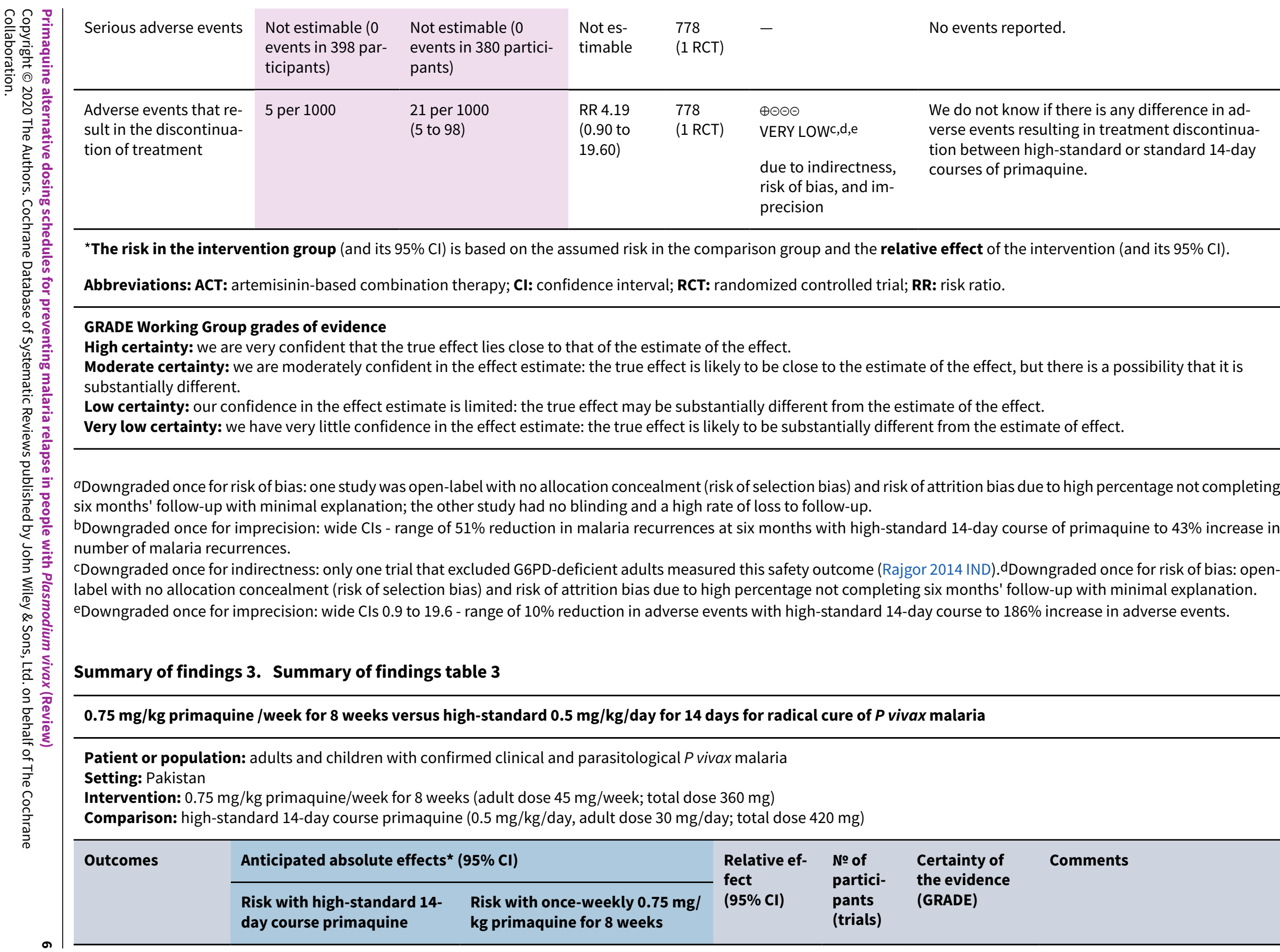

\section{GRADE Working Group grades of evidence}

. ubstantially different.

Low certainty: our confidence in the effect estimate is limited: the true effect may be substantially different from the estimate of the effect.

(the estimate of effect.

bDowngraded once for imprecision: wide Cls - range of $51 \%$ reduction in malaria recurrences at six months with high-standard 14 -day course of primaquine to $43 \%$ increase in

cDowngraded once for indirectness: only one trial that excluded G6PD-deficient adults measured this safety outcome (Rajgor 2014 IND) dDowngraded once for risk of bias: openlabel with no allocation concealment (risk of selection bias) and risk of attrition bias due to high percentage not completing six months' follow-up with minimal explanation.

\section{Summary of findings 3. Summary of findings table 3}

$0.75 \mathrm{mg} / \mathrm{kg}$ primaquine /week for 8 weeks versus high-standard $0.5 \mathrm{mg} / \mathrm{kg} /$ day for 14 days for radical cure of $P$ vivax malaria

Setting: Pakistan

Intervention: $0.75 \mathrm{mg} / \mathrm{kg}$ primaquine/week for 8 weeks (adult dose $45 \mathrm{mg} /$ week; total dose $360 \mathrm{mg}$ )

Comparison: high-standard 14-day course primaquine $(0.5 \mathrm{mg} / \mathrm{kg} /$ day, adult dose $30 \mathrm{mg} /$ day; total dose $420 \mathrm{mg}$ ) 


\begin{tabular}{|c|c|c|c|c|c|c|c|}
\hline 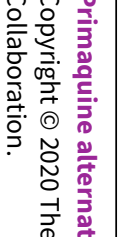 & $\begin{array}{l}\text { Recurrence of } P \text { vi- } \\
\text { vax malaria } \\
\text { Follow-up: } 11 \\
\text { months }\end{array}$ & 19 per 1000 & $\begin{array}{l}59 \text { per } 1000 \\
(7 \text { to } 511)\end{array}$ & $\begin{array}{l}\text { RR } 3.18 \\
(0.37 \text { to } \\
27.60)\end{array}$ & $\begin{array}{l}122 \\
(1 \mathrm{RCT})\end{array}$ & $\begin{array}{l}\oplus \odot \odot \ominus \\
\text { VERY LOWa,b } \\
\text { due to risk of } \\
\text { bias and serious } \\
\text { imprecision }\end{array}$ & $\begin{array}{l}\text { We do not know if weekly pri- } \\
\text { maquine reduces the risk of } \\
\text { malaria recurrences when com- } \\
\text { pared to the high-standard 14- } \\
\text { day course. }\end{array}$ \\
\hline $\begin{array}{l}\overline{\bar{\sigma}} \\
\overline{0} \\
\overline{0} \\
\bar{v}\end{array}$ & $\begin{array}{l}\text { Serious adverse } \\
\text { events }\end{array}$ & $\begin{array}{l}\text { Not estimable ( } 0 \text { events in } 55 \\
\text { participants) }\end{array}$ & $\begin{array}{l}\text { Not estimable ( } 0 \text { events in } 74 \text { par- } \\
\text { ticipants) }\end{array}$ & $\begin{array}{l}\text { Not es- } \\
\text { timable }\end{array}$ & $\begin{array}{l}129 \\
(1 \mathrm{RCT})\end{array}$ & - & No events reported. \\
\hline 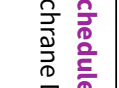 & $\begin{array}{l}\text { Anaemia (haemo- } \\
\text { globin }<7 \mathrm{~g} / \mathrm{dL} \text { ) }\end{array}$ & $\begin{array}{l}\text { Not estimable ( } 0 \text { events in } 55 \\
\text { participants) }\end{array}$ & $\begin{array}{l}\text { Not estimable ( } 0 \text { events in } 74 \text { par- } \\
\text { ticipants) }\end{array}$ & $\begin{array}{l}\text { Not es- } \\
\text { timable }\end{array}$ & $\begin{array}{l}129 \\
(1 \mathrm{RCT})\end{array}$ & - & No events reported. \\
\hline
\end{tabular}

${ }^{*}$ The risk in the intervention group (and its $95 \% \mathrm{Cl}$ ) is based on the assumed risk in the comparison group and the relative effect of the intervention (and its $95 \% \mathrm{Cl}$ ).

Abbreviations: $\mathbf{C l}$ : confidence interval; RCT: randomized controlled trial; RR: risk ratio.

\section{GRADE Working Group grades of evidence}

High certainty: we are very confident that the true effect lies close to that of the estimate of the effect.

Moderate certainty: we are moderately confident in the effect estimate: the true effect is likely to be close to the estimate of the effect, but there is a possibility that it is

substantially different.

Low certainty: our confidence in the effect estimate is limited: the true effect may be substantially different from the estimate of the effect.

Very low certainty: we have very little confidence in the effect estimate: the true effect is likely to be substantially different from the estimate of effect.

aDowngraded once for risk of bias: Leslie 2008 PAK was at high risk of bias for randomization process, allocation concealment, and incomplete outcome data.

bDowngraded twice for serious imprecision: few events, very wide Cls that incorporated a potential large beneficial effect and a potential large harmful effect.

\section{Summary of findings 4 . Summary of findings table 4}

\section{$1.0 \mathrm{mg} / \mathrm{kg}$ primaquine /day for 7 days versus high-standard $0.5 \mathrm{mg} / \mathrm{kg} /$ day for 14 days for radical cure of $P$ vivax malaria}

Patient or population: adults and children with confirmed clinical and parasitological $P$ vivax malaria

Settings: Afghanistan, Ethiopia, Indonesia, Thailand, and Vietnam

Intervention: $1.0 \mathrm{mg} / \mathrm{kg} /$ day primaquine for 7 days (adult dose $60 \mathrm{mg} /$ day; total dose $420 \mathrm{mg}$ )

Comparison: high-standard 14-day course primaquine $(0.5 \mathrm{mg} / \mathrm{kg} /$ day, adult dose $30 \mathrm{mg} /$ day; total dose $420 \mathrm{mg})$

\begin{tabular}{|c|c|c|c|c|c|c|}
\hline \multirow[t]{2}{*}{ Outcomes } & \multicolumn{2}{|c|}{$\begin{array}{l}\text { Anticipated absolute } \\
\text { effects }^{\star}(95 \% \mathrm{CI})\end{array}$} & \multirow{2}{*}{$\begin{array}{l}\text { Relative } \\
\text { effect } \\
(95 \% \mathrm{CI})\end{array}$} & \multirow{2}{*}{$\begin{array}{l}\text { № of } \\
\text { Partici- } \\
\text { pants } \\
\text { (trials) }\end{array}$} & \multirow{2}{*}{$\begin{array}{l}\text { Certainty of the evi- } \\
\text { dence } \\
\text { (GRADE) }\end{array}$} & \multirow[t]{2}{*}{ Comments } \\
\hline & $\begin{array}{l}\text { Risk } \\
\text { with }\end{array}$ & $\begin{array}{l}\text { Risk with } \\
1.0 \mathrm{mg} / \mathrm{kg} /\end{array}$ & & & & \\
\hline
\end{tabular}




\begin{tabular}{|c|c|c|c|c|c|c|}
\hline \multicolumn{7}{|c|}{$\begin{array}{l}\text { high- } \\
\text { stan- } \\
\text { dard } \\
\text { 14-day } \\
\text { course } \\
\text { pri- } \\
\text { maquine }\end{array}$} \\
\hline $\begin{array}{l}\text { Recurrence of } P \text { vi- } \\
\text { vax parasitaemia } \\
\text { Follow-up: } 12 \\
\text { months }\end{array}$ & $\begin{array}{l}104 \text { per } \\
1000\end{array}$ & $\begin{array}{l}107 \text { per } 1000 \\
\text { (85 to } 135)\end{array}$ & $\begin{array}{l}\text { RR } 1.03 \\
(0.82 \text { to } \\
1.30)\end{array}$ & $\begin{array}{l}2526 \\
\text { (2 RCTs) }\end{array}$ & $\begin{array}{l}\oplus \oplus \oplus \odot^{a} \\
\text { MODERATE } \\
\text { due to risk of bias }\end{array}$ & $\begin{array}{l}\text { There is probably little or no difference between } 1.0 \mathrm{mg} / \mathrm{kg} / \text { day pri- } \\
\text { maquine for } 7 \text { days and the high-standard } 0.5 \mathrm{mg} / \mathrm{kg} / \mathrm{day} \text { for } 14 \text { days } \\
\text { course }\end{array}$ \\
\hline $\begin{array}{l}\text { Serious adverse } \\
\text { events } \\
\text { Follow-up: up to } 42 \\
\text { days }\end{array}$ & $\begin{array}{l}1 \text { per } \\
1000\end{array}$ & $\begin{array}{l}13 \text { per } 1000 \\
(2 \text { to } 99)\end{array}$ & $\begin{array}{l}\text { RR } 12.03 \\
\text { (1.57 to } \\
92.30)\end{array}$ & $\begin{array}{l}1872 \\
(1 \mathrm{RCT})\end{array}$ & $\begin{array}{l}\oplus \oplus \ominus \ominus^{b, c} \\
\text { LOW } \\
\text { due to indirectness } \\
\text { and imprecision }\end{array}$ & $\begin{array}{l}\text { There may be a moderate to large increase in serious adverse events } \\
\text { in the } 1.0 \mathrm{mg} / \mathrm{kg} / \mathrm{day} \text { primaquine for } 7 \text { days compared with the high- } \\
\text { standard } 0.5 \mathrm{mg} / \mathrm{kg} / \text { day } \\
\text { Chu } 2019 \mathrm{THA} \text { provides overall narrative results only, see Effects of in- } \\
\text { terventions text. }\end{array}$ \\
\hline $\begin{array}{l}\text { Adverse events the } \\
\text { resulted in discon- } \\
\text { tinuation of treat- } \\
\text { ment }\end{array}$ & $\begin{array}{l}2 \text { per } \\
1000\end{array}$ & $\begin{array}{l}4 \text { per } 1000 \\
(1 \text { to } 20)\end{array}$ & $\begin{array}{l}\text { RR } 2.50 \\
(0.49 \text { to } \\
12.87)\end{array}$ & $\begin{array}{l}2526 \\
\text { (2 RCTs) }\end{array}$ & $\begin{array}{l}\oplus \ominus \ominus \ominus \text { a,b,d } \\
\text { VERY LOW } \\
\text { due to risk of bias, in- } \\
\text { directness and serious } \\
\text { imprecision }\end{array}$ & $\begin{array}{l}\text { We do not know if there is any difference in adverse events resulting in } \\
\text { treatment discontinuation between } 1.0 \mathrm{mg} / \mathrm{kg} / \text { day primaquine for } 7 \\
\text { days and the high-standard } 0.5 \mathrm{mg} / \mathrm{kg} / \text { day for } 14 \text { days course. }\end{array}$ \\
\hline $\begin{array}{l}\text { Anaemia } \\
\text { Follow-up: be- } \\
\text { tween } 3 \text { and } 42 \\
\text { days follow-up }\end{array}$ & $\begin{array}{l}35 \text { per } \\
1000\end{array}$ & $\begin{array}{l}33 \text { per } 1000 \\
(22 \text { to } 50)\end{array}$ & $\begin{array}{l}\text { RR } 0.93 \\
(0.62 \text { to } \\
1.41)\end{array}$ & $\begin{array}{l}2440 \\
\text { ( } 2 \text { stud- } \\
\text { ies) }\end{array}$ & $\begin{array}{l}\oplus \ominus \ominus \ominus^{\mathrm{a}, \mathrm{b}, \mathrm{e}} \\
\text { VERY LOW } \\
\text { due to risk of bias, in- } \\
\text { directness and impre- } \\
\text { cision }\end{array}$ & $\begin{array}{l}\text { We do not know if there is any difference in anaemia between } 1.0 \mathrm{mg} / \\
\mathrm{kg} / \text { day primaquine for } 7 \text { days and the high-standard } 0.5 \mathrm{mg} / \mathrm{kg} / \mathrm{day} \\
\text { for } 14 \text { days course. }\end{array}$ \\
\hline
\end{tabular}

${ }^{*}$ The risk in the intervention group (and its $95 \% \mathrm{Cl}$ ) is based on the assumed risk in the comparison group and the relative effect of the intervention (and its $95 \% \mathrm{Cl}$ ). Cl: Confidence interval; DHA-PPQ: dihydroartemisinin-piperaquine; RCT: randomized controlled trial; RR: Risk Ratio

GRADE Working Group grades of evidence

High certainty: we are very confident that the true effect lies close to that of the estimate of the effect.

Moderate certainty: we are moderately confident in the effect estimate: the true effect is likely to be close to the estimate of the effect, but there is a possibility that it is substantially different.

Low certainty: our confidence in the effect estimate is limited: the true effect may be substantially different from the estimate of the effect.

Very low certainty: we have very little confidence in the effect estimate: the true effect is likely to be substantially different from the estimate of effect. 
aDowngraded once for risk of bias: Chu 2019 THA was an open-label trial with high risk of performance and detection bias; although drop-outs were balanced between groups the proportion of drop-outs after one year was high in both trials (30-40\%).

bDowngraded once for indirectness: G6PD-deficient children and adults were excluded from the two trials that measured this outcome (Chu 2019 THA; Taylor 2019 MULTI).

Downgraded once for imprecision: few events.

dDowngraded twice for imprecision: few events and a very wide $95 \% \mathrm{Cl}$ that incorporated a potential large beneficial effect and a potential large harmful effect.

eDowngraded once for imprecision: few events and a wide $95 \% \mathrm{Cl}$ that incorporated a potential moderate beneficial effect and a potential moderate harmful effect. 


\section{B A C K G R O U N D}

Malaria is a potentially life-threatening disease caused by the Plasmodium parasite, which is transmitted by the bite of an infected female Anopheles mosquito. Five species of Plasmodium malaria parasites can cause malaria disease in humans, of which Plasmodium vivax and Plasmodium falciparum are the most important (WHO 2016). In 2018, an estimated 228 million cases of malaria occurred worldwide and an estimated 405,000 people died from the disease (WHO 2019). The World Health Organization (WHO) aims to reduce malaria case load and mortality by at least $90 \%$ by 2030 (WHO 2016).

Historically, $P$ vivax infection was thought to be a milder form of malaria, and researchers have focused on $P$ falciparum due to the high number of deaths it causes (Bassat 2016). In recent years, it has been shown that the morbidity and mortality of $P$ vivax have been underestimated, with evidence of direct fatality and contribution to mortality in patients who have other comorbidities, such as malnutrition, HIV, or coexisting infections (Baird 2013; Bhattacharjee 2013; Rizvi 2013; Singh 2013; Battle 2014; Douglas 2014; Kochar 2014; Arévalo-Herrera 2015; Baird 2015b). Repeated $P$ vivax infections through childhood and adulthood also affect personal well-being, development, and education and can thus negatively impact economic development, both for the individual and the community (Mendis 2001). P vivax malaria in pregnancy is associated with maternal anaemia, spontaneous abortion, stillbirth, and low birthweight, with especially poor pregnancy outcomes for women with severe infection (McGready 2012; Rijken 2012; Brutus 2013).

\section{Description of the condition}

$P$ vivax infection caused an estimated 7.5 million cases of malaria in 2018 (WHO 2019). The geographical distribution of $P$ vivax malaria is more widespread than any of the other forms of human malaria, with around $35 \%$ of the world's population thought to be at risk (Howes 2016). Co-infection with $P$ falciparum is also common in many regions (Kumar 2007; Mueller 2009). As malaria control accelerates, the $P$ vivax proportion in co-endemic areas tends to rise compared to that of $P$ falciparum, which highlights the importance and challenge of this infection (John 2012).

$P$ vivax is important because as many countries progress towards malaria elimination, the parasite becomes a roadblock to eradication (Cibulskis 2015; Bassat 2016). Despite a reported 45\% reduction in $P$ vivax malaria cases between 2010 and 2016 (WHO 2017), the parasite has several characteristics that enable it to evade control (Newby 2016). The early appearance of gametocytes in the blood, often prior to symptoms of malaria, increases the chance of onward transmission by mosquitoes (Mendis 2001). $P$ vivax differs from $P$ falciparum in that as well as having a bloodstage infection, hypnozoites develop in the liver that can be dormant for weeks to months before developing into an infection (White 2011). What triggers these relapses is not well-understood. There is difficulty in distinguishing between relapse (hypnozoite activation), recrudescence (subpar treatment of the initial bloodstage infection), and re-infection (new infection with $P$ vivax) (Imwong 2007). A study in Papua New Guinea suggested that relapses cause four-fifths of $P$ vivax infections (Robinson 2015), reinforcing the importance of relapse in sustaining transmission (White 2011). Parasites show high genetic diversity, even in countries that are at malaria elimination stage (Koepfli 2015). $P$ vivax is likely underestimated worldwide, as the dormant liver stage is not detected in routine surveys (Gething 2012). Submicroscopic infections and asymptomatic infection reservoirs may also lead to underdiagnosis or misdiagnosis. A systematic review showed that across all study sites, the polymerase chain reaction (PCR) prevalence of $P$ viva $x$ was significantly higher than that identified by light microscopy (Cheng 2015). The effect this may have on $P$ vivax malaria studies is unclear.

There are different strains of $P$ vivax according to geographical region/endemicity areas, with relapse patterns that vary by latency (time to first relapse), likelihood of relapse, and frequency of relapses, which further complicates the assessment of efficacy of drugs on relapses (Battle 2014; White 2016). Strains commonly found in Southeast Asia and Oceania (including the 'Chesson' strain isolated from an individual infected in Papua New Guinea) have the shortest latency time to relapse, starting as early as three weeks after first infection (if untreated with a hypnozoiticidal drug) (Ehrman 1945). These areas correspond to zones 10 and 12 in Battle 2014. Indian and Pakistan strains (zone 8) exhibit heterogeneity in relapse latency, incidence, and frequency, while South American strains (zone 3) have a pattern of short latency to first relapse and less frequent relapses than in zones 10 and 12 (Battle 2014). The temperate strains (which include those from Korea in zone 11) relapse much more slowly (John 2012; Battle 2014). Strains of the type in zones 10 and 12, referred to here as 'East Asia and Oceania', are recommended to receive higher doses of primaquine (the highstandard course of $0.5 \mathrm{mg} / \mathrm{kg} /$ day rather than standard $0.25 \mathrm{mg} / \mathrm{kg} /$ day for 14 days) to prevent relapses (WHO 2015), apparently based on research done in the 1950s and 1960s (Coatney 1953; Jones 1953; Vivona 1961; Maffi 1971; Clyde 1977), although not all these studies were done with strains from the targeted geographic area.

Primaquine, an 8-aminoquinoline, has until very recently been the only drug available on the market for treating the hypnozoite stage of infection (Ashley 2014). One of the main barriers in $P$ vivax treatment is the reluctance to use primaquine due to it potentially causing haemolysis in patients with glucose-6phosphate dehydrogenase (G6PD) deficiency. G6PD deficiency is the most common enzyme deficiency worldwide and affects red blood cells by leading to their premature lysis (Nkhoma 2009). G6PD deficiency is common in countries where $P$ vivax malaria is endemic, with an estimated population prevalence of $8 \%$ (Howes 2012). Within G6PD deficiency, there are differing phenotypes, meaning some people may be mildly sensitive to primaquine, while others may be very sensitive and experience life-threatening haemolysis (Baird 2015a), which explains the varying responses to primaquine. In many areas where $P$ vivax is predominant, testing for G6PD deficiency is not available locally (Baird 2015b). In 2018 the US Food and Drug Administration (FDA) approved a newer alternative, another 8-aminoquinoline known as tafenoquine (MMV 2018), which has shown promise in reducing relapses, but there are increased safety concerns in patients with undiagnosed G6PD deficiency compared to primaquine, due to its longer half-life (Rajapakse 2015).

\section{Description of the intervention}

People with $P$ vivax malaria require treatment with an antimalarial drug to treat the blood-stage infection, and a drug to treat the hypnozoite stage (radical cure). The WHO recommends treatment with either chloroquine or an artemisinin-based combination therapy (ACT) for the blood-stage infection, with 0.25 to $0.5 \mathrm{mg} /$ 
$\mathrm{kg} /$ day primaquine for 14 days for the liver stages (WHO 2015). Artemisinin-based combination therapies and chloroquine have been shown to be effective and comparable in treating the bloodstage infection of $P$ vivax malaria (Gogtay 2013).

A previous Cochrane Review showed that primaquine regimens of five days or fewer had similar recurrence rates to placebo or no primaquine. Of the comparisons included in the review, a regimen of $0.25 \mathrm{mg} / \mathrm{kg} /$ day $(15 \mathrm{mg})$ a day of primaquine for 14 days had the lowest recurrence rates of $P$ vivax infection (Galappaththy 2013). There were no trials at that time that compared higher doses of primaquine at 14 or 7 days.

Primaquine was first made available to North American soldiers in the 1950s (Baird 2004). Its mechanism and metabolism are not widely understood, but it has a broad spectrum of activity against the Plasmodium parasite. As well as preventing relapse of $P$ vivax malaria by targeting the latent and developing hypnozoites in the liver, it is also used in malaria prophylaxis (Baird 2003) and is gametocytocidal (Graves 2018). It is absorbed from the gastrointestinal tract, has a half-life of about four to nine hours, and crosses the placenta in pregnancy (Baird 2004). New advancements in studying $P$ vivax in humanized mice may lead to a greater understanding of the mechanism of action of the drug (Mikolajczak 2015).

Adverse events observed with primaquine include production of methaemoglobin, an oxidated state of haemoglobin that cannot transport oxygen to tissues. Methaemoglobinaemia (an abnormal buildup of methaemoglobin) can result in cyanosis when levels exceed $10 \%$ of the usual haemoglobin level (Vale 2009). As described above, primaquine causes haemolysis in people with G6PD deficiency, which leads to anaemia (Ashley 2014). When taken on an empty stomach it can cause abdominal pain and gastrointestinal upset (Vale 2009). Safe use of primaquine during pregnancy has not been established. The radical cure with primaquine can be delayed until after pregnancy. With regard to breastfeeding patients, a recent study showed that the levels of primaquine in breast milk may not be sufficient to cause haemolysis even in a G6PD-deficient baby (Gilder 2018), but it is not recommended at this time.

\section{How the intervention might work}

The WHO advises that $0.25 \mathrm{mg}$ (standard) to $0.5 \mathrm{mg} / \mathrm{kg} / \mathrm{day}$ (high standard) of primaquine for 14 days (total dose $210 \mathrm{mg}$ or 420 $\mathrm{mg}$ ) should be used for radical cure of $P$ vivax malaria in patients over six months old, excluding people with G6PD deficiency and those who are pregnant or breastfeeding (WHO 2015). Citing the review previous Cochrane Review of this topic (Galappaththy 2013), the WHO notes that the standard regimen reduced relapses during 15 months of follow-up by about $40 \%$ compared to placebo or no primaquine (high-quality evidence), and reduced relapses during six months follow-up by over 50\% compared to seven days primaquine (low-quality evidence) (WHO 2015). The increased dosing in the high standard $0.5 \mathrm{mg} / \mathrm{kg} /$ day regimen was previously recommended in East Asia and Oceania based on suggestion of failure of the standard regimen of $0.25 \mathrm{mg} / \mathrm{kg} /$ day for 14 days for strains of $P$ vivax in these areas (including the Chesson strain). The guidelines note that "no direct comparison has been made of higher doses ( $0.5 \mathrm{mg} / \mathrm{kg}$ bw for 14 days) with the standard regimen $(0.25 \mathrm{mg} / \mathrm{kg}$ bw for 14 days)". Given that the 15 trials included in the WHO assessment excluded G6PD-deficient persons (12 trials) or did not comment on their exclusion, WHO guidelines also stated "in the absence of evidence to recommend alternatives, the guidelines development group consider $0.75 \mathrm{mg} / \mathrm{kg}$ bw primaquine given once weekly for 8 weeks to be the safest regimen for people with mild to moderate G6PD deficiency", but no trials of this regimen were included in the WHO guidance (WHO 2015).

The 14-day course of primaquine at any dose, as well as the eightweek course, can lead to treatment adherence issues, as well as to safety concerns about haemolysis in places where G6PD testing is not available, meaning that shorter courses of primaquine are desirable. Failure to treat the hypnozoite stage of $P$ vivax malaria leads to repeated relapses, morbidity, and persistent infection.

It has long been suggested that it may be the total dose of primaquine that is important in the treatment of the hypnozoite stage rather than the length of the course (Schmidt 1977). If a higher dose of primaquine could be administered safely over a shorter period of time, it may improve adherence rates, thus reducing relapse rates and morbidity and mortality resulting from $P$ vivax infection. There are small trials from the 1970s that suggest that shorter, higher-dose regimens were as efficacious as the 14-day courses (Clyde 1977; Saint-Yves 1977). At the time of the previous Cochrane Review (Galappaththy 2013), there were no recent large high-quality trials that had investigated the use of the same total dose as the standard regimen $(210 \mathrm{mg})$, or higher total doses, given over either shorter or longer periods. We planned to include any such trials in this Cochrane Review.

\section{Why it is important to do this review}

The use of primaquine for radical cure of $P$ vivax malaria continues to pose a therapeutic dilemma for healthcare providers in areas without adequate screening for G6PD status. Clinicians must either choose to give primaquine and risk haemolysis if the patient is G6PD-deficient, or withhold treatment and accept the complications of ongoing parasite infection and relapses. This is why when clinicians choose to treat with primaquine they prefer a lower dose over a more prolonged period, which then risks difficulties with adherence and thus reduced effectiveness.

We know from the previous Cochrane Review on primaquine with chloroquine for radical cure that the standard 14-day regimen of $0.25 \mathrm{mg} / \mathrm{kg} /$ day ( $15 \mathrm{mg}$ per day or $210 \mathrm{mg}$ total dose) is better than shorter regimens of similar daily doses and placebo (Galappaththy 2013). In fact, the regimen of $0.25 \mathrm{mg} / \mathrm{kg} /$ day for five days of primaquine did not reduce recurrences compared to treating with chloroquine alone.

A major problem with the radical cure of $P$ vivax is difficulty with the adherence to the 14-day course of primaquine, which has led to many countries shortening the regimen. Peru was one such example, although a study revealed that patients often still discontinued the therapy after around three days, when they started to feel better (Grietens 2010). A study that compared directly observed therapy (DOT) for 14 days of primaquine versus non-DOT primaquine found that the $P$ vivax recurrence rate was significantly lower in the DOT group (Takeuchi 2010). These problems have led to a more urgent call for shorter treatment regimens. Various trials are investigating regimens that revise dosing and duration of treatment in order to improve adherence and reduce the potential for incomplete treatment and development of resistance. As mentioned previously, the significance of the total cumulative 
primaquine dose given, rather than the length of the course, is one avenue of investigation. In areas where G6PD screening is present, using higher dosing regimens over shorter time periods, if at least similarly efficacious, could improve adherence and reduce morbidity associated with $P$ vivax parasitaemia.

World Health Organization guidelines suggest a higher dosing regimen of primaquine for the tropical, frequent-relapsing strains of $P$ vivax in East Asia and Oceania (WHO 2015), although the previous Cochrane Review, Galappaththy 2013, did not find any trials assessing this. Investigating the evidence base for this is therefore important. The 2015 WHO guidelines also suggest an alternate dosing regimen of weekly primaquine, which may be safer in patients with G6PD deficiency. As the previous Cochrane Review included data from only one trial assessing this, it is useful to investigate whether there is further evidence to substantiate this guidance.

In this Cochrane Review, we have excluded comparisons between blood-stage drug (chloroquine/ACT) with and without primaquine, as the rationale for primaquine use has been sufficiently demonstrated in a previous Cochrane Review (Galappaththy 2013). Similarly, we have not included comparisons between different blood-stage drugs in which the same dose of primaquine was used; an update to an existing Cochrane Review, Gogtay 2013, is in progress and will address this. However, we planned to stratify our results according to partner drug, as there is increasing evidence that primaquine is metabolized via the cytochrome P450 2D6 (CYP2D6) pathway (Bennett 2013), and efficacy may thus be affected if the blood-stage antimalarial drug is a CYP2D6 inhibitor (Baird 2018). This review excluded comparisons that do not use the standard $(0.25 \mathrm{mg} / \mathrm{kg} /$ day $)$ or high-standard $(0.5 \mathrm{mg} / \mathrm{kg} /$ day $)$ regimens of 14 days of primaquine in the control groups. Also, it did not include comparisons of primaquine regimens of $0.25 \mathrm{mg} /$ $\mathrm{kg} /$ day for less than 14 days, as Galappaththy 2013 has already assessed these shorter regimens at this dose.

There is currently a lack of consensus among studies as to what the minimum time frame for follow-up of relapse in $P$ vivax malaria should be. The WHO guidance on clinical trials in malaria sets out standard follow-up for blood (or schizontal) stage infection as 28 days after treatment commencement, but has no clear definition on the follow-up period for radical cure in primaquine studies. It states that "follow up varies from three months to a year in the literature, and should be adapted to regional parasite characteristics" (WHO 2009). In a recent review, John 2012 described relapse of the tropical frequently relapsing strain of $P$ vivax as typically three weeks, but this varies according to blood-stage treatment: "three weeks following quinine therapy" and "six to eight weeks following chloroquine" (White 2011). With exposure to primaquine - even if radical cure is not achieved - relapses may occur at longer intervals (Sutanto 2013). In the Cochrane Review (Galappaththy 2013), the follow-up period started 30 days after completing primaquine treatment. Relapse is frequently defined as the presence of $P$ vivax parasites more than 28 to 30 days after the full course of primaquine in people living in a non-endemic area (Looareesuwan 1997). Due to the varying lengths of treatment and relapse time in P vivax malaria, 28 days from treatment completion may not allow true assessment of radical cure. It also makes assessment of the weekly primaquine regimen difficult, as the follow-up time should start before the eight-week treatment course has finished. In this Cochrane Review we planned to assess parasitaemia at three, six, and 12 months' follow-up, in keeping with WHO guidance. We intended to describe the length of follow-up across studies, and then group them into meaningful lengths of follow-up, depending on the regimen.

Attention is needed to the problems of lack of completion of long treatment courses and potential insufficient dosing in some geographical areas, while maintaining daily doses within a safe range. We compare the efficacy and safety of alternative schedules to those currently recommended, or those with insufficient evidence in current recommendations. Specifically, we intended to answer the following questions by comparing alternative regimens with total adult dose of over $210 \mathrm{mg}$ to the standard 14-day regimen of primaquine $(0.25 \mathrm{mg} / \mathrm{kg} /$ day, $15 \mathrm{mg}$ adult daily dose, total dose $210 \mathrm{mg})$, or the high-standard 14-day regimen $(0.5 \mathrm{mg} / \mathrm{kg} /$ day, 30 mg adult daily dose, total dose $420 \mathrm{mg}$ ).

- Is a shorter, higher daily dose regimen with same or higher total dose, given over seven days, as (or more) efficacious and safe as the standard or high standard regimens given over 14 days? (Comparisons 1 and 4)

- Is the high-standard 14-day regimen, with higher daily and total dose, as (or more) efficacious and safe as the standard 14-day course, in all areas and/or where it was formerly recommended (East Asia and Oceania)? (Comparison 2)

- Is a weekly dosing regimen with higher daily dose given one day a week and with either higher or lower total dose, as (or more) efficacious and safe as the standard or high-standard 14day regimens? (Comparison 3 )

\section{O B JECTIVES}

To assess the efficacy and safety of alternative primaquine regimens with total adult dose $>210 \mathrm{mg}$ for radical cure of $P$ vivax malaria compared to the standard or high-standard 14 days of primaquine $(0.25 \mathrm{mg} / \mathrm{kg} /$ day or $0.5 \mathrm{mg} / \mathrm{kg} /$ day, total adult dose $210 \mathrm{mg}$ or $420 \mathrm{mg}$ ), as well as comparison of these two WHOrecommended regimens.

\section{METHODS}

\section{Criteria for considering studies for this review}

\section{Types of studies}

Randomized controlled trials (RCTs). We excluded quasi-RCTs.

\section{Types of participants}

Adults and children with confirmed clinical and parasitological (light microscopy or PCR, or both) diagnosis of $P$ vivax malaria. We included trials that excluded people with G6PD deficiency and trials that included populations that had or had not been screened for G6PD deficiency. People with mixed malaria infections were excluded.

\section{Types of interventions}

\section{Intervention}

Any regimen of either chloroquine or an artemisinin-based combination therapy (ACT) plus primaquine at total adult dose $>210 \mathrm{mg}$ in any of the following categories.

Daily doses higher than $0.25 \mathrm{mg} / \mathrm{kg} /$ day (15 mg daily adult dose, total dose $210 \mathrm{mg}$ ) for 14 days. 
- Shorter regimens with the same or higher total dose than the regimen they are being compared to i.e. standard or high standard regimen.

- Weekly dosing regimens.

\section{Control}

WHO-defined standard regimen of 14 days of primaquine at 0.25 $\mathrm{mg} / \mathrm{kg} /$ day (15 mg daily adult dose, total dose $210 \mathrm{mg}$ ), or highstandard regimen of $0.5 \mathrm{mg} / \mathrm{kg} /$ day for 14 days (30 mg adult daily dose, total dose $420 \mathrm{mg}$ ), plus either chloroquine or an ACT as the treatment for blood-borne infection. Where possible, we stratified by the blood schizonticidal agent.

\section{Types of outcome measures}

\section{Primary outcomes}

- $P$ vivax parasitaemia (detected by light microscopy or PCR, or both) at 3, 6, and 12 months' follow-up. We planned to describe this as recurrences of $P$ vivax malaria due to the previously mentioned difficulties in distinguishing between relapse and reinfection.

\section{Secondary outcomes}

- P vivax parasitaemia (detected by light microscopy or PCR, or both) at one to three months' follow-up.

\section{Adverse events}

- Serious adverse events (fatal, life-threatening, or requiring hospitalization)

- Adverse events that result in discontinuation of treatment.

- Anaemia or change in haemoglobin status.

- Other adverse events.

\section{Search methods for identification of studies}

We attempted to identify all relevant studies regardless of language or publication status (published, unpublished, in press, or in progress).

\section{Electronic searches}

We searched the following databases using the search terms and strategy described in Appendix 1: the Cochrane Infectious Diseases Group Specialized Register (2 September 2019); the Cochrane Central Register of Controlled Trials (CENTRAL, 2018 , Issue 12, published in the Cochrane Library); MEDLINE (PubMed, 1946 to 2 September 2019); Embase (Ovid, 1947 to 2 September 2019); and LILACS (Bireme, 1982 to 2 September 2019). We also searched the World Health Organization (WHO) International Clinical Trials Registry Platform (ICTRP; www.who.int/ictrp/), and ClinicalTrials.gov (clinicaltrials.gov/ct2/home), for trials in progress, on 2 September 2019, using "primaquine" and "vivax" as search terms.

\section{Searching other resources}

We checked the reference lists of all studies identified by the above methods for additional potentially relevant studies. We contacted researchers working in the field and the WHO for unpublished and ongoing trials. We also searched the reference lists and included studies of the Cochrane Review Galappaththy 2013.

\section{Data collection and analysis}

\section{Selection of studies}

Two review authors independently screened the titles and abstracts of the search results to identify potentially eligible trials, coding the articles as either 'retrieve' or 'do not retrieve'. We obtained the full-text reports of potentially eligible trials and assessed them for inclusion in the review using a predesigned eligibility form based on the inclusion criteria. Any discrepancies were resolved through discussion or by consulting a third review author if necessary. Where necessary, we contacted the trial authors for clarification of trial methods. We listed the excluded trials and the reasons for their exclusion in a Characteristics of excluded studies table. Where there were multiple reports relating to the same trial, we planned to include all reports and collate data. We detailed the trial selection process in a PRISMA diagram.

\section{Data extraction and management}

Two review authors independently extracted data from the included trials using a data extraction form designed specifically for this review, in keeping with Cochrane guidance (Higgins 2011).

For each included trial we extracted a minimum of the following data where available.

- Study design.

- Endemicity/population demographics.

- G6PD status of participants (known/unknown).

- CYP2D6 status (if available).

- Blood-stage antimalarial drug choice.

- Dose/duration/timing of treatment arms.

- Supervised or non-supervised therapy.

- Duration of follow-up.

- Adverse events.

- Reported outcomes.

Any differences in data extraction were resolved through discussion or by consulting a third review author if necessary. We entered the extracted data into Review Manager 5 (RevMan 5) (Review Manager 2014). Where necessary, we contacted the authors of primary trials regarding missing data or methodological details of the trial. We noted any limitations in the included studies.

We grouped comparisons as illustrated in Table 1.

\section{Assessment of risk of bias in included studies}

Two review authors independently assessed the risk of bias of each included trial using the Cochrane 'Risk of bias' assessment tool, discussing any differences of opinion. In the case of missing or unclear information, we contacted the trial authors for clarification. We summarized the results in the 'Risk of bias' tables in the Characteristics of included studies tables (Higgins 2011).

\section{Measures of treatment effect}

For dichotomous data, we compared interventions using risk ratios (RRs) to measure treatment effect. Where trial authors presented data as odds ratios, we recalculated the effect. We defined statistical significance as $\mathrm{P}<0.05$ and calculated $95 \%$ confidence intervals (Cls) for all results. For comparable trials, we performed meta-analyses if there were sufficient data. 
We also extracted measures of rate ratio and hazard ratio when reported by trials, and summarized these in appendices.

\section{Unit of analysis issues}

We split trials that included more than two comparison groups and analysed them as individual pair-wise comparisons. If there was a shared control group, we split the control group so that participants were only counted once in the overall meta-analysis.

\section{Dealing with missing data}

We analysed missing data using available-case analysis if we judged the trial to be at low risk of bias for incomplete outcome data. We attempted to contact trial authors to obtain missing or unclear data. If the missing data rendered the result uninterpretable, we excluded the data from meta-analyses and clearly stated the reason for exclusion. If the missing data meant that results were interpretable but likely to be at high risk of bias, we planned to use imputation methods to investigate the impact of the missing data. We analysed extracted data on an intention-to-treat basis where there were no missing data.

\section{Assessment of heterogeneity}

We inspected forest plots for overlapping Cls. We also applied the $\mathrm{Chi}^{2}$ test as a statistical test for the presence of heterogeneity, with a $P$ value of 0.10 used to indicate statistical significance, and we computed the $\mathrm{I}^{2}$ statistic to quantify the percentage of the variability in effect estimates that was due to heterogeneity rather than sampling error (chance). We investigated possible causes of heterogeneity by subgroup analysis. If substantive heterogeneity persisted, defined as an $\mathrm{I}^{2}$ statistic value of greater than $50 \%$, we used a random-effects meta-analysis.

\section{Assessment of reporting biases}

We planned to examine the likelihood of reporting bias using funnel plots, however the number of included trials was insufficient to permit this.

\section{Data synthesis}

We analysed the data using RevMan 5 (Review Manager 2014). We assessed the certainty of the evidence for each outcome measure using the GRADE approach, and we constructed 'Summary of findings' tables using GRADEpro GDT (GRADEpro GDT 2015). We grouped the analyses by drug regimen and stratified results according to blood-stage partner drug (if different blood-stage antimalarials were used). Length of follow-up varied with regimens and between studies. We conducted an inventory of length of follow-up against each drug regimen and then grouped $P$ vivax parasitaemia recurrence by appropriate groupings for length of follow-up and stratified data accordingly.

\section{Subgroup analysis and investigation of heterogeneity}

We performed subgroup analyses according to geographical region/endemicity and directly observed therapy (DOT) or nonDOT. We had planned to perform a subgroup analysis according to CYP2D6 status, however data were insufficient to permit this.

\section{Sensitivity analysis}

We planned to assess the risk of bias of studies that contributed data to the meta-analyses for the prespecified outcomes with sensitivity analyses against concealment of allocation.

\section{RESULTS}

\section{Description of studies}

\section{Results of the search}

Our database update search, conducted up to 2 September 2019 , identified 44 studies. We excluded 38 articles during abstract screening, and selected six studies for full-text review. We excluded four studies with reasons provided, and included one new reference with outcome data for a previously ongoing study (Taylor 2019 MULTI) ,and one new reference with outcome data for an already included study that had not provided any data in the previous version of this review (Chu 2019 THA). Following this update search, this review now contains 11 included studies, 29 excluded studies and one ongoing study. The search results and screening process for this update are presented in a PRISMA diagram in Figure 1. 
Figure 1. Study flow diagram.

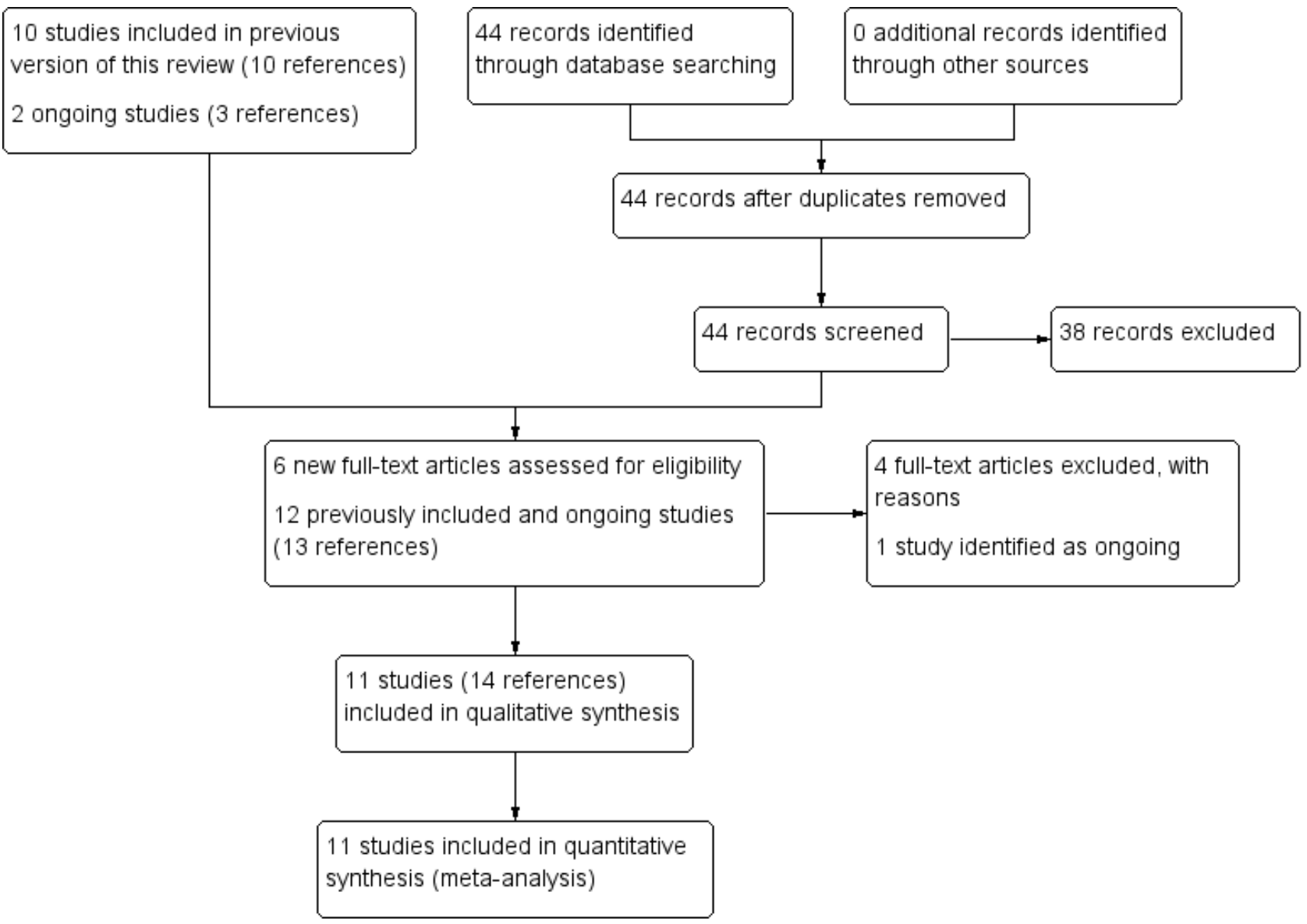

\section{Included studies}

We included 11 studies (of 11 trials) in our quantitative analysis.

One trial was multinational and conducted in Africa (Ethiopia) and Asia (Afghanistan, Indonesia, and Vietnam) (Taylor 2019 MULTI). Four trials were conducted in South America: one in Colombia (Carmona-Fonseca 2009 COL), one in Brazil (Abdon 2001 BRA), and two in Peru (Solari-Soto 2002 PER; Durand 2014 PER). Six trials were conducted in Asia: one in Pakistan (Leslie 2008 PAK), two in Thailand (Bunnag 1994 THA; Chu 2019 THA), and three in India (Rajgor 2014 IND; Pareek 2015 IND; Saravu 2018 IND).

Eight trials were funded by not for profit organizations, government agencies, or academia. One trial was funded by the drug manufacturer (Pareek 2015 IND), and two trials did not report their source of funding (Bunnag 1994 THA; Abdon 2001 BRA).

All 11 trials included data for adults, and six trials included children under the age of 10 years (Solari-Soto 2002 PER; Leslie 2008 PAK; Carmona-Fonseca 2009 COL; Durand 2014 PER; Chu 2019 THA; Taylor 2019 MULTI). Two trials (Chu 2019 THA; Taylor 2019 MULTI) included children from the age of six months.

Nine trials excluded pregnant women, and two trials did not specify whether or not pregnant women were included (Bunnag 1994 THA; Solari-Soto 2002 PER). Eight trials specified that lactating women were excluded, while the remaining three trials did not provide details regarding this (Bunnag 1994 THA; Solari-Soto 2002 PER;
Carmona-Fonseca 2009 COL). Only one trial included people with G6PD deficiency (Leslie 2008 PAK). Eight trials excluded people with G6PD deficiency (Bunnag 1994 THA; Carmona-Fonseca 2009 COL; Durand 2014 PER; Rajgor 2014 IND; Pareek 2015 IND; Saravu 2018 IND; Chu 2019 THA; Taylor 2019 MULTI), and two trials did not specify whether or not people with G6PD deficiency were included (Abdon 2001 BRA; Solari-Soto 2002 PER).

All of the trials used microscopy for diagnosis of parasitaemia. Four trials carried out polymerase chain reaction (PCR) genotyping of vivax parasitaemia as well (Durand 2014 PER; Rajgor 2014 IND; Pareek 2015 IND; Saravu 2018 IND).

Two trials used different doses or regimens of chloroquine within trial arms, but as both confirmed that parasitaemia had resolved following treatment, we still included them in the review (see Characteristics of included studies) (Bunnag 1994 THA; Abdon 2001 BRA). None of the included trials described the CYP2D6 status of participants.

\section{Excluded studies}

We excluded 29 studies during full-text screening; see details in Characteristics of excluded studies. 


\section{Risk of bias in included studies}

A summary of the 'Risk of bias' assessments is presented in Figure 2. Full details are shown in the Characteristics of included studies tables.

Figure 2. 'Risk of bias' summary: review authors' judgements about each 'Risk of bias' item for each included study.

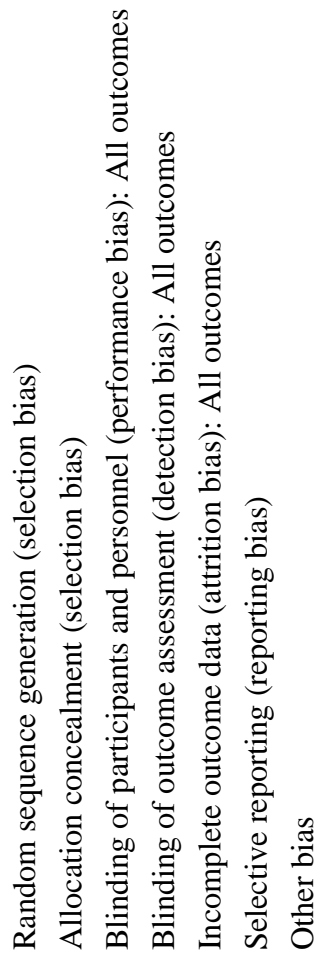

\begin{tabular}{|c|c|c|c|c|c|c|c|}
\hline Abdon 2001 BRA & $?$ & $?$ & - & - & + & + & $?$ \\
\hline Bunnag 1994 THA & $?$ & $?$ & + & $?$ & $\odot$ & $?$ & $?$ \\
\hline Carmona-Fonseca 2009 COL & $?$ & $?$ & - & 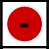 & + & $?$ & + \\
\hline Chu 2019 THA & + & $?$ & 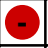 & - & $?$ & + & + \\
\hline Durand 2014 PER & + & + & - & $\odot$ & + & + & + \\
\hline Leslie 2008 PAK & - & 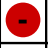 & & + & - & + & + \\
\hline Pareek 2015 IND & + & + & + & $?$ & + & - & $?$ \\
\hline Rajgor 2014 IND & + & - & $=$ & + & - & $?$ & + \\
\hline Saravu 2018 IND & + & $?$ & 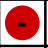 & - & - & + & + \\
\hline Solari-Soto 2002 PER & $?$ & $?$ & 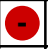 & $?$ & + & $?$ & + \\
\hline Taylor 2019 MULTI & + & + & + & + & $?$ & + & + \\
\hline
\end{tabular}

\section{Allocation}

Six trials described adequate methods of treatment randomization and were judged to be at low risk of selection bias (Durand 2014 PER; Rajgor 2014 IND; Pareek 2015 IND; Saravu 2018 IND; Chu 2019 THA; Taylor 2019 MULTI). We assessed one trial as being at high risk of bias as it used two different methods of randomization depending on location, using house numbers or sequential patient numbers (Leslie 2008 PAK). Four trials did not detail the randomization process (Bunnag 1994 THA; Abdon 2001 BRA; Solari-Soto 2002 PER; Carmona-Fonseca 2009 COL).

Two trials used sealed envelopes to conceal allocation (Durand 2014 PER; Pareek 2015 IND) and an independent statistician held the group assignments in one trial (Taylor 2019 MULTI), so these three trials were assessed as being at low risk of bias. We assessed 
two trials with no concealment of treatment allocation as at high risk of bias (Leslie 2008 PAK; Rajgor 2014 IND), while six trials provided no information on whether or not allocation concealment was used (Bunnag 1994 THA; Abdon 2001 BRA; Solari-Soto 2002 PER; Carmona-Fonseca 2009 COL; Saravu 2018 IND; Chu 2019 THA).

\section{Blinding}

Eight trials were open-label and were assessed as at high risk of performance bias (Abdon 2001 BRA; Solari-Soto 2002 PER; Leslie 2008 PAK; Carmona-Fonseca 2009 COL; Durand 2014 PER; Rajgor 2014 IND; Saravu 2018 IND; Chu 2019 THA). The remaining three trials reported blinding of participants and personnel, and were classified as being at low risk of performance bias (Bunnag 1994 THA; Pareek 2015 IND; Taylor 2019 MULTI). Flve trials were at high risk of detection bias (Abdon 2001 BRA; Carmona-Fonseca 2009 COL; Durand 2014 PER; Saravu 2018 IND; Chu 2019 THA); they were all open-label trials that did not report any details of blinding outcome assessment. Three trials were at unclear risk of detection bias. They were either double-blind trials that did not report any details as to whether microscopy was blinded or whether there was double reading of smears (Bunnag 1994 THA; Pareek 2015 IND), or an open-label trial that mentioned double-checking of smears but did not clarify whether outcome assessment was blinded (SolariSoto 2002 PER). Three trials were at low risk of detection bias; they reported blinding of the microscopists who read the slides (Leslie 2008 PAK; Rajgor 2014 IND; Taylor 2019 MULTI).

\section{Incomplete outcome data}

Five trials had low rates of attrition with losses accounted for and so were judged as at low risk of attrition bias (Abdon 2001 BRA; Solari-Soto 2002 PER; Carmona-Fonseca 2009 COL; Durand 2014 PER; Pareek 2015 IND). We assessed four trials as at high risk of attrition bias. Bunnag 1994 THA had unexplained, significant loss to follow-up (more than three-quarters of participants by the end of the trial), making the results uninterpretable. Leslie 2008 PAK had a higher loss to follow-up in the intervention group compared to the control group (6\% loss versus 1\% loss). Rajgor 2014 IND had a high percentage of missing results at six months. Saravu 2018 IND had a high percentage of loss to follow-up in both arms by six months. Two trials were assessed as at unclear risk of attrition bias (Chu 2019 THA; Taylor 2019 MULTI), both had high rates of dropouts, but this was after one year and rates were balanced between groups and reasons for dropping out were provided.

\section{Selective reporting}

We judged six trials to have adequately reported on either prespecified or expected outcomes (Abdon 2001 BRA; Leslie 2008 PAK; Durand 2014 PER; Saravu 2018 IND; Chu 2019 THA; Taylor 2019 MULTI). Risk of reporting bias was unclear for four trials as no protocols were available (Bunnag 1994 THA; Solari-Soto 2002 PER; Carmona-Fonseca 2009 COL; Rajgor 2014 IND). We assessed Pareek 2015 IND as being at high risk of reporting bias because compliance was added as an outcome, primaquine levels were not reported as planned, and PCR results were not well-detailed.

\section{Other potential sources of bias}

We assessed eight trials as at low risk of other bias (Solari-Soto 2002 PER; Leslie 2008 PAK; Carmona-Fonseca 2009 COL; Durand 2014 PER; Rajgor 2014 IND; Saravu 2018 IND; Chu 2019 THA; Taylor 2019 MULTI). We assessed Pareek 2015 IND to be at unclear risk of other bias as it was funded by the drug company that manufactured the primaquine preparations, and the authors were employees of the company. Another two trials, for which funding was not detailed, were also assessed as at unclear risk of other bias (Bunnag 1994 THA; Abdon 2001 BRA).

\section{Effects of interventions}

See: Summary of findings 1 Summary of findings table 1 (main comparison); Summary of findings 2 Summary of findings table 2; Summary of findings 3 Summary of findings table 3; Summary of findings 4 Summary of findings table 4

\section{Comparison 1: $0.5 \mathrm{mg} / \mathrm{kg} /$ day for seven days versus standard $0.25 \mathrm{mg} / \mathrm{kg} /$ day for 14 days}

This comparison aimed to investigate whether a shorter, higherdose regimen of primaquine over seven days is as efficacious as standard treatment over 14 days to determine whether the total dose rather than the length of treatment is an important factor (total dose $210 \mathrm{mg}$ ).

Five trials in India and South America compared $0.5 \mathrm{mg} / \mathrm{kg} /$ day of primaquine for seven days versus the standard $(0.25 \mathrm{mg} / \mathrm{kg} /$ day) 14-day regimen (same total dose $210 \mathrm{mg}$ ) (Abdon $2001 \mathrm{BRA}$; Solari-Soto 2002 PER; Durand 2014 PER; Rajgor 2014 IND; Pareek 2015 IND). Pareek 2015 IND used a sustained-release preparation of primaquine in two of the study arms $(0.5 \mathrm{mg} / \mathrm{kg} /$ day sustained release and $0.25 \mathrm{mg} / \mathrm{kg} /$ day sustained release) and standard primaquine at $0.25 \mathrm{mg} / \mathrm{kg} /$ day in a third arm. We included the $0.5 \mathrm{mg} / \mathrm{kg} /$ day sustained release in the analysis and combined the results with the standard preparation at the same dose used for the other trials, but used only the standard-preparation group of 0.25 $\mathrm{mg} / \mathrm{kg} /$ day in the study as the control group and did not include the arm of $0.25 \mathrm{mg} / \mathrm{kg} /$ day sustained release preparation.

Three trials excluded people with G6PD deficiency, while two trials did not provide this information (Bunnag 1994 THA; SolariSoto 2002 PER). All but one trial excluded women who were pregnant or lactating (Solari-Soto 2002 PER did not provide details). Participants were a mixture of adults and children over one-year old. All trials used microscopy for diagnosis, and only Pareek 2015 IND did not use supervised treatment. Two trials gave chloroquine and primaquine courses simultaneously (Abdon 2001 BRA; Durand 2014 PER), while the other three trials administered primaquine following the chloroquine course. No trials stratified by age, so results were combined.

\section{Efficacy}

There was minimal difference in the number of malaria recurrences between groups at six to seven months' follow-up (risk ratio (RR) $0.96,95 \%$ confidence interval (Cl) 0.66 to 1.39 ; 4 trials, 1211 participants; low-certainty evidence; Analysis 1.1). One trial only followed participants for two months (Solari-Soto 2002 PER), and so was not part of the main analysis.

We had planned to perform a sensitivity analysis based on risk of bias for allocation concealment (which would have involved removing Rajgor 2014 IND from the meta-analysis), but we decided that as the remaining trials were all at high risk of bias for blinding and thus quality was generally low, we would not conduct a sensitivity analysis but address these issues in our GRADE assessment. 
Two trials PCR-adjusted their results to differentiate between relapses and new infections at six to seven months' follow-up. In Durand 2014 PER, PCR-adjusted results showed a 31\% reduction in recurrence ( $24 \%$ reduction with light microscopy) with the regimen of $0.5 \mathrm{mg} / \mathrm{kg} /$ day for seven days compared with the standard 14day course, while in Rajgor 2014 IND, PCR-adjusted results showed a $159 \%$ increase in recurrence $(25 \%$ increase in recurrence with light microscopy) with the regimen of $0.5 \mathrm{mg} / \mathrm{kg} /$ day for seven days compared to the standard 14-day regimen (Analysis 1.2). We decided that these results could not be combined in a metaanalysis, as PCR techniques can differ, and there were high levels of heterogeneity.

We performed a subgroup analysis according to geographic region (Analysis 1.3). For trials in South America, the regimen of 0.5 $\mathrm{mg} / \mathrm{kg} /$ day for seven days led to a $30 \%$ reduction in $P$ vivax recurrences compared to a $19 \%$ increase in recurrences for trials in Asia, although Cls were wide and included no effect for both subgroups (South America: RR 0.70, 95\% Cl 0.39 to 1.26; 2 trials, 397 participants; Asia: RR 1.19, $95 \% \mathrm{Cl} 0.73$ to 1.94; 2 trials, 814 participants). Only one trial did not use directly observed therapy (DOT) (Pareek 2015 IND). Subgroup analysis (Analysis 1.4) showed that with DOT there was minimal difference in recurrences at six to seven months between treatment regimens (RR 0.98, 95\% Cl 0.67 to $1.43 ; 1017$ participants) compared to a reduction of about half of recurrences with the regimen of $0.5 \mathrm{mg} / \mathrm{kg} /$ day for seven days when treatment was not supervised (RR $0.48,95 \% \mathrm{Cl} 0.04$ to 5.20 ; 194 participants).

\section{Adverse events}

No serious adverse events were reported in either group (5 trials, 1427 participants, Analysis 1.5). The number of participants experiencing adverse events leading to discontinuation of treatment was similar in both groups (very low-certainty evidence, RR $1.04,95 \% \mathrm{Cl} 0.15$ to 7.38; 5 trials, 1427 participants; Analysis 1.6). Only one study reported on adverse events during chloroquine administration (Rajgor 2014 IND), with more occurring in the group receiving $0.5 \mathrm{mg} / \mathrm{kg} /$ day for seven days than the standard 14-day group (RR 9.40, 95\% Cl 0.51 to 174.01; one trial, 779 participants; Analysis 1.7). There was no difference in adverse events occurring during primaquine administration ( $\mathrm{RR} 1.64, \mathrm{Cl} 0.75$ to $3.57 ; 2$ trials,1019 participants; Analysis 1.8). There was no difference between arms in other adverse events (RR $0.56,95 \% \mathrm{Cl} 0.23$ to 1.36 ; 2 trials,135 participants; Analysis 1.9).

One trial reported on change in haemoglobin status (Pareek 2015 IND), with one participant out of 120 in the group receiving $0.5 \mathrm{mg} /$ $\mathrm{kg} /$ day for seven days becoming anaemic, versus no participants out of 120 in the standard 14-day regimen group (very low-certainty evidence, RR 3.00, 95\% Cl 0.12 to $72.91 ; 240$ participants; Analysis 1.10).

Durand 2014 PER noted that the arms with higher daily primaquine dose did not present significantly higher frequency of the five symptoms (fever, chills, headache, muscular pain, and dark urine) monitored during treatment.

Details on the nature of the adverse events are reported in Appendix 2.

\section{Comparison 2: high-standard $0.5 \mathrm{mg} / \mathrm{kg} /$ day for 14 days versus standard $0.25 \mathrm{mg} / \mathrm{kg} /$ day for 14 days}

The World Health Organization (WHO) recommends higher doses of primaquine $(0.5 \mathrm{mg} / \mathrm{kg} / \mathrm{day})$ for 14 days in East Asia and Oceania. We intended to examine whether this high-standard regimen was more efficacious in areas where it is currently recommended (East Asia and Oceania), as well as in all other areas where it has been used due to perceived resistance or strain differences.

Two trials compared the high-standard 14-day course with the standard $(0.25 \mathrm{mg} / \mathrm{kg} /$ day) 14-day course, both carried out in adults in India (Rajgor 2014 IND; Saravu 2018 IND). Both trials excluded pregnant/lactating women and G6PD-deficient patients. In Rajgor 2014 IND, participants were treated with chloroquine, with the primaquine regimen (which was supervised) given after completion of the chloroquine course. In Saravu 2018 IND, participants were treated with either chloroquine or an artemisininbased combination therapy (ACT) (artesunate with doxycycline or artemether-lumefantrine), and (unsupervised) primaquine was given after completion of the blood-stage treatment. We planned to stratify results according to blood-stage treatment; however, Saravu 2018 IND combined the results for both blood-stage treatments, so we were unable to separate results according to partner drug. Only the blood-stage drugs given to participants who had recurrences were described. Results from the two studies are presented separately in subgroups, but are also combined.

\section{Efficacy}

The combined estimate for both trials suggests little or no difference between the arms: (RR $0.84,95 \% \mathrm{Cl} 0.49$ to $1.43 ; 2$ trials, 677 participants, low-certainty evidence, test for subgroup differences, $12=0 \%)$.

In Rajgor 2014 IND, 21 participants out of 317 in the high-standard 14-day group had a recurrence of vivax malaria compared with 26 out of 322 in the standard 14-day group at six-month followup, giving an $18 \%$ reduction in recurrence of parasitaemia in the high-standard group (RR 0.82, 95\% $\mathrm{Cl} 0.47$ to 1.43 ; 639 participants; Analysis 2.1). $P$ vivax malaria recurrences were also investigated by PCR to determine whether they were true relapses or new infections. After this adjustment, results showed an $83 \%$ increase in $P$ vivax malaria cases in the high-standard group (RR $1.83,95 \% \mathrm{Cl}$ 0.62 to 5.40; Analysis 2.2). Rajgor 2014 IND was at high risk of bias for allocation concealment.

Saravu 2018 IND was a small open-label pilot trial in which participants were given either chloroquine or ACT depending on clinician's judgement of severity. $78 \%$ of participants were given chloroquine $76 \%$ in the standard arm and $80 \%$ in the highstandard arm). In Saravu 2018 IND, two out of 18 participants in the high-standard 14-day group had a recurrence of $P$ vivax malaria compared to two out of 20 in the standard 14-day group at six months' follow-up (RR 1.11, 95\% Cl 0.17 to 7.09; Analysis 2.1). Polymerase chain reaction (PCR) genotyping suggested that all four participants had true relapses of infection.

\section{Adverse events}

In Rajgor 2014 IND there were no serious adverse events reported in either study arm (778 participants). In the high-standard 14day group, eight out of 380 participants discontinued treatment due to adverse events (one participant discontinued chloroquine 
and seven participants discontinued primaquine), compared to two out of 398 in the standard 14-day group (both participants discontinued primaquine) (RR 4.19, $95 \% \mathrm{Cl} 0.90$ to $19.60 ; 778$ participants; Analysis 2.4). In the high-standard arm during chloroquine treatment, four out of 380 participants experienced adverse events compared to zero out of 398 in the standard group (RR 9.43, 95\% Cl 0.51 to 174.47; 778 participants; Analysis 2.5). In the high-standard arm during primaquine treatment, 13 out of 380 participants experienced adverse events known to occur with primaquine, compared to five out of 398 in the standard arm (RR 2.72, $95 \% \mathrm{Cl} 0.98$ to 7.57 ; 778 participants; Analysis 2.5). These results could suggest a trend towards higher occurrence of adverse events in the high-standard 14-day regimen. Details on the nature of the adverse events are reported in Appendix 2.

No significant adverse events were noted in either group in Saravu 2018 IND.

\section{Comparison 3: $0.75 \mathrm{mg} / \mathrm{kg} /$ week for eight weeks versus high- standard $0.5 \mathrm{mg} / \mathrm{kg} /$ day for 14 days}

This comparison aimed to investigate whether a higher onceweekly dosing regimen, which may be more beneficial for people with G6PD deficiency, was as efficacious as the high-standard 14day regimen.

One trial compared weekly $0.75 \mathrm{mg} / \mathrm{kg}$ primaquine $(45 \mathrm{mg}$ adult dose) for eight weeks with the high-standard 14-day regimen $(0.5$ $\mathrm{mg} / \mathrm{kg} /$ day) (Leslie 2008 PAK). G6PD-deficient participants were not randomized but were included in the weekly group, although there only was one G6PD-deficient person included. Pregnant and lactating women were excluded. Treatment was supervised. It was not specified whether chloroquine and primaquine were given concurrently.

\section{Efficacy}

Recurrences were more common in the weekly group at eight months' follow-up (RR $7.00,95 \% \mathrm{Cl} 0.38$ to $127.32 ; 126$ participants; Analysis 3.1). Recurrences remained more common in the weekly group at 11 months' follow-up (RR 3.18, 95\% Cl 0.37 to $27.60 ; 122$ participants; very low-certainty evidence; Analysis 3.1). Leslie 2008 PAK was at high risk of bias for allocation concealment, but a sensitivity analysis could not be done as it was the only trial found for this comparison.

\section{Adverse events}

No serious adverse events (Analysis 3.2) or notable non-serious adverse events (Analysis 3.4) were reported in either study arm. No participants had anaemia defined as haemoglobin less than $7 \mathrm{~g} / \mathrm{dL}$ (Analysis 3.3).

\section{Comparison 4: $1 \mathrm{mg} / \mathrm{kg} /$ day for seven days versus high- standard $0.5 \mathrm{mg} / \mathrm{kg} /$ day for 14 days}

This comparison aimed to investigate whether shorter, higher doses of primaquine over seven days are as effective as the high-standard 14-day regimen; i.e. to determine whether the total dose rather than the length of treatment is the important factor (total dose $420 \mathrm{mg}$ primaquine). Two trials conducted in Ethiopia, Afghanistan, Indonesia, Thailand, and Vietnam compared $1 \mathrm{mg} /$ $\mathrm{kg} /$ day (adult dose $60 \mathrm{mg}$ ) of primaquine for seven days with the high-standard 14-day course $(0.5 \mathrm{mg} / \mathrm{kg} /$ day, adult dose 30 mg/day) (Chu 2019 THA; Taylor 2019 MULTI), administering the regimen with either chloroquine or an $\mathrm{ACT}$ (dihydroartemisininpiperaquine (DHA-PPQ). We stratified the results accordingly. Both trials excluded people with G6PD deficiency, however, both trials included those with G6PD deficiency in parallel observational cohorts. Women who were pregnant or lactating were excluded. Participants were a mixture of adults and children over six months old. Both trials used microscopy for diagnosis, and both trials used supervised treatment. Taylor 2019 MULTI gave chloroquine or DHAPPQ and primaquine courses simultaneously, while Chu 2019 THA did not specify whether primaquine was given concurrently, before, or after blood-stage drug. No trials stratified by age, so results were combined.

\section{Efficacy}

\section{Primary outcome}

Little or no difference was detected in recurrence of $P$ vivax malaria after 12 months between $1 \mathrm{mg} / \mathrm{kg} /$ day for seven days compared with the high-standard 14-day regimen in two trials (RR $1.03,95 \% \mathrm{Cl} 0.82$ to $1.30 ; 2526$ participants, moderate-certainty evidence, Analysis 4.1). Rate ratios and hazard ratios support the RR estimate and are reported in Appendix 3 The results were similar for the chloroquine subgroup (RR $0.91,95 \% \mathrm{Cl} 0.67$ to $1.22 ; 1404$ participants) and for the DHA-PPQ subgroup (RR 1.24, 95\% Cl 0.87 to $1.77 ; 1122$ participants). Results were also similar for subgroups by geographical region (Analysis 4.2).

Only one trial (Chu 2019 THA) reported risk ratios at six and three months. There was little or no difference detected in recurrence of $P$ vivax malaria after six months (RR $1.10,95 \% \mathrm{Cl} 0.61$ to 1.97 ; 1 RCT, 474 participants; Analysis 4.3) and after three months (RR $0.94,95 \% \mathrm{Cl} 0.41$ to 2.14; $1 \mathrm{RCT}, 522$ participants; Analysis 4.4). Results subgrouped by blood-stage drug were similar, but results were imprecise due to wide $95 \% \mathrm{Cls}$.

Taylor 2019 MULTI did not report risk ratios at six and three months that could be pooled with the main results. Rate ratios from this study are presented in Appendix 3, and they also show little or no difference in recurrences between the two arms.

\section{Secondary outcome}

Taylor 2019 MULTI reported on short-term follow-up of $P$ vivax parasitaemia. Little or no difference was detected for $P$ vivax parasitaemia after 28 days (RR $0.67,95 \% \mathrm{Cl} 0.11$ to $3.99 ; 1872$ participants; Analysis 4.5), and after 42 days (RR $1.00,95 \% \mathrm{Cl} 0.35$ to 2.85; 1872 participants; Analysis 4.5). The estimates are uncertain due to very wide $95 \%$ Cls.

\section{Adverse events}

There may be moderate to large increase in serious adverse events in the $1.0 \mathrm{mg} / \mathrm{kg} /$ day primaquine for seven days group compared with the high-standard $0.5 \mathrm{mg} / \mathrm{kg} /$ day at 42 days (RR $12.03,95 \%$ $\mathrm{Cl} 1.57$ to $92.30 ; 1872$ participants; low-certainty evidence; Analysis 4.6), and at one year follow-up (RR $3.61,95 \% \mathrm{Cl} 1.35$ to 9.68; 1872 participants; Analysis 4.6). The absolute numbers reported by Taylor 2019 MULTI at 42 days and one year were 12 and 18 serious adverse events in the primaquine $1 \mathrm{mg} / \mathrm{kg} / \mathrm{day}$ for seven days group among 935 participants compared to one and five in the control arm among 937 participants, respectively. Of the 12 serious adverse events reported at 42 days in the $1 \mathrm{mg} / \mathrm{kg} /$ day group, nine were regarded as being possibly, probably, or definitely related to primaquine (details of each event from Taylor 
2019 MULTI supplementary files are given in Appendix 2). At one year, an additional six serious adverse events deemed unrelated to primaquine were reported in the $1 \mathrm{mg} / \mathrm{kg} /$ day group. Only one of the five serious adverse events in the high-standard 14 day regimen (observed by 42 days) was deemed probably related to primaquine (Appendix 2).

Chu 2019 THA only provides a narrative summary and does not report serious adverse events per group. The authors noted that there were 30 serious adverse events reported; most common were methaemoglobinaemia $(n=10)$, haemolysis $(n=3)$, and presumed bacterial infection $(n=10)$. Four deaths occurred. None was considered related to the study drugs (follow-up, up to 42 days).

There is probably no difference in adverse events leading to discontinuation of treatment between both groups (RR 2.50, 95\% $\mathrm{Cl} 0.49$ to $12.87 ; 2$ trials, 2526 participants; very low-certainty evidence; Analysis 4.7). However, the evidence is very uncertain due to risk of bias and wide $95 \% \mathrm{Cls}$.

Taylor 2019 MULTI reported 1819 adverse events among the 935 participants in the seven-day primaquine group and 1732 events among the 937 participants in the 14-day primaquine group; Chu 2019 THA reported 169 events among the 327 participants in the seven-day primaquine group and 173 events among the 327 participants in the 14-day primaquine group (Analysis 4.8).

Full details on the nature of adverse events are reported in Appendix 2.

There is probably no difference in haemoglobin status between both groups (RR 0.93, Cl 95\% 0.62 to $1.41 ; 2$ trials, 2440 participants; very low-certainty evidence; Analysis 4.9). However, the evidence is very uncertain due to risk of bias and wide $95 \% \mathrm{Cls}$.

\section{Comparisons 5 and 6: other regimens}

\section{$0.375 \mathrm{mg} / \mathrm{kg} /$ day for 14 days versus standard 14-day regimen}

Bunnag 1994 THA compared $0.375 \mathrm{mg} / \mathrm{kg} /$ day (adult dose $22.5 \mathrm{mg}$ ) primaquine daily for 14 days with the standard regimen of $0.25 \mathrm{mg} /$ $\mathrm{kg} /$ day for 14 days. There was a high loss to follow-up, with 167 participants enrolled and only 38 completing 18 months' follow-up, although the loss was equal in both groups at the end of followup. At six months' follow-up there were no episodes of $P$ vivax in the experimental group (0/40) and two recurrences in the standardregimen group (2/33) (RR $0.17,95 \% \mathrm{Cl} 0.01$ to 3.34 ; 73 participants; Analysis 5.1), although only about half of enrolled participants were followed up at this time point. No further recurrences were described in either group up to the end of follow-up at 18 months, but as described, the high level of unexplained dropout makes interpretation difficult.

No formal assessment of adverse events was reported, but it is mentioned in the study narrative that patients tolerated the medication well and no serious adverse effect was seen in either group.There was no drop in haematocrit, or haemoglobinuria in either group.

\section{$1.17 \mathrm{mg} / \mathrm{kg} /$ day for three days versus standard 14-day regimen}

One trial delivered the total dose of primaquine $(1.17 \mathrm{mg} / \mathrm{kg} /$ day or $70 \mathrm{mg}$ adult dose, total dose $210 \mathrm{mg}$ ) over three days versus the standard $(0.25 \mathrm{mg} / \mathrm{kg} /$ day) 14-day regimen (Carmona-Fonseca
2009 COL). Recurrences of $P$ vivax malaria were more common in the group receiving $1.17 \mathrm{mg} / \mathrm{kg} /$ day for three days than in the standard 14-day group at 4 months' follow-up (RR 3.88, 95\% Cl 2.11 to $7.11 ; 129$ participants; Analysis 6.1).

Adverse events were not reported, although it was noted that there were no serious adverse events from co-administering primaquine and chloroquine.

\section{DISCUSSION}

\section{Summary of main results}

\section{Comparison 1 (main comparison): $0.5 \mathrm{mg} / \mathrm{kg} /$ day for seven days versus standard $0.25 \mathrm{mg} / \mathrm{kg} /$ day for 14 days}

See Summary of findings 1

We included five randomised controlled trials (RCTs) that compared $0.5 \mathrm{mg} / \mathrm{kg} /$ day (adult dose $30 \mathrm{mg}$ ) primaquine for seven days with the standard 14-day regimen $(0.25 \mathrm{mg} / \mathrm{kg} /$ day $)$. There may be little or no difference in $P$ vivax recurrences at six to seven months when using the same total dose $(210 \mathrm{mg})$ over seven days as compared to 14 days (low-certainty evidence). No serious adverse events were reported. There may be little or no difference in the number of adverse events during primaquine treatment when using the shorter regimen as compared to the longer regimen.

We do not know whether there is any difference in the frequency of anaemia or discontinuation of treatment between groups (very low-certainty evidence). Three trials excluded people with G6PD deficiency, and two did not provide this information, so we do not know the effect of the higher daily-dose regimen in this group. Pregnant and lactating women were either excluded or this information was not provided.

\section{Comparison 2: high-standard $0.5 \mathrm{mg} / \mathrm{kg}$ for 14 days versus standard $0.25 \mathrm{mg} / \mathrm{kg} /$ day for 14 days}

See Summary of findings 2

We included two RCTs that compared $0.5 \mathrm{mg} / \mathrm{kg} /$ day primaquine (daily adult dose $30 \mathrm{mg}$ ) for 14 days with $0.25 \mathrm{mg} / \mathrm{kg} /$ day (daily adult dose $15 \mathrm{mg}$ ) for 14 days, both conducted in India. The total dose differed between arms, being $420 \mathrm{mg}$ in the high standard arm and $210 \mathrm{mg}$ in the standard arm. People with G6PD deficiency and pregnant or lactating women were excluded. One trial did not account for whether participants were given chloroquine or an artemisinin-based combination therapy (ACT) for blood-stage treatment.

There may be little or no difference in $P$ vivax recurrences at six months with the high-standard 14-day course compared to the standard 14-day course when given with chloroquine or an ACT. No differences were observed when primaquine was given either with chloroquine, or with chloroquine or ACT.

No serious events were reported in either trial. We do not know whether there is a difference in adverse events leading to discontinuation between the high-standard 14-day course and the standard 14-day course (very low-certainty evidence).

\section{Comparison 3: $0.75 \mathrm{mg} / \mathrm{kg} /$ week for eight weeks versus high- standard $0.5 \mathrm{mg} / \mathrm{kg} / \mathrm{day}$ for 14 days}

See Summary of findings 3 
We included one RCT that compared $0.75 \mathrm{mg} / \mathrm{kg}$ (daily adult dose $45 \mathrm{mg}$ ) weekly primaquine for eight weeks with the high-standard 14-day regimen $(0.5 \mathrm{mg} / \mathrm{kg} /$ day, daily adult dose $30 \mathrm{mg})$. The total dose was $360 \mathrm{mg}$ in the weekly arm versus $420 \mathrm{mg}$ in the highstandard arm. G6PD-deficient participants were not randomized but were included in the weekly primaquine group. Only one G6PDdeficient participant was detected during the trial and was included in the weekly group.

We do not know whether weekly primaquine reduces recurrence of $P$ vivax compared to the high-standard 14-day regimen at eight to 11 months' follow-up (very low-certainty evidence).

No serious adverse events and no episodes of anaemia were reported.

\section{Comparison 4: $1.0 \mathrm{mg} / \mathrm{kg} /$ day for seven days versus high- standard $0.5 \mathrm{mg} / \mathrm{kg} /$ day for 14 days}

See Summary of findings 4

We included two RCTS (one a large multicentre trial) that compared a new high dose of $1 \mathrm{mg} / \mathrm{kg} /$ day for seven days with the highstandard course. The total dose of $420 \mathrm{mg}$ was the same for both arms. G6PD-deficient participants were excluded from one trial; in the other trial, patients with G6PD deficiency were excluded from the randomised trial, but were enrolled into a parallel observational group receiving weekly primaquine.

There is probably little or no difference in recurrences between $1.0 \mathrm{mg} / \mathrm{kg} /$ day primaquine for seven days and the high-standard $0.5 \mathrm{mg} / \mathrm{kg} /$ day for 14 days course at 12 months follow-up (moderate-certainty evidence). No differences were observed when primaquine was given with chloroquine or dihydroartemisininpiperaquine (DHA-PPQ).

There may be moderate to large increase in serious adverse events with $1.0 \mathrm{mg} / \mathrm{kg} /$ day primaquine for seven days compared with the high-standard $0.5 \mathrm{mg} / \mathrm{kg} /$ day, as reported by one trial (Taylor 2019 MULTI) at 42 days and one-year follow-up (low-certainty evidence); the other trial reported narrative summary only (Chu 2019 THA). We do not know if there is difference in anaemia at 42 days follow-up or in adverse events leading to discontinuation (very low-certainty evidence).

\section{Comparisons 5 and 6: other regimens}

Some other included trials evaluated alternative regimens and doses of primaquine, but these regimens have not been widely used, and the evidence available from stand-alone trials was limited.

\section{Overall completeness and applicability of evidence}

Although the evidence is currently of low certainty, it appears from Comparison 1 that using $0.5 \mathrm{mg} / \mathrm{kg} /$ day with the same total dose (210 $\mathrm{mg}$ ) over seven days may be non-inferior to the regimen of $0.25 \mathrm{mg} / \mathrm{kg} /$ day for 14 days. It is likely that this shorter regimen would promote course completion. No serious adverse events were reported in the five trials in this comparison. However, this sevenday regimen was not tested in G6PD-deficient patients in any of the RCTs meeting our inclusion criteria. This remains a concern in settings where testing is not available.
We initially planned to evaluate whether the high-standard 14day regimen $(0.5 \mathrm{mg} / \mathrm{kg} /$ day) was more effective in areas where recommended by the World Health Organization (WHO) due to reported resistance or strain differences (East Asia and Oceania), as well as in other areas (WHO 2015). However, the two randomized clinical trials that compared the efficacy of high-standard to the standard regimen were both conducted in India (Rajgor 2014 IND; Saravu 2018 IND), where the high-standard regimen is not recommended. A recent retrospective case review in French Guiana (also an area where the high-standard regimen is not currently recommended) found that recurrences were similar in both standard and high-standard 14-day regimens (Valdes 2018). We did not find any RCTs that evaluated whether the high-standard 14-day regimen was more effective compared to the standard 14day regimen for the tropical, frequently relapsing strain of $P$ vivax in East Asia and Oceania, so we are unable to comment on its efficacy.

Only one included RCT investigated the weekly primaquine regimen that is currently recommended by WHO for G6PD-deficient individuals, and only one G6PD-deficient participant was actually included in the trial.

We found two trials of a new high dose $1.0 \mathrm{mg} / \mathrm{kg} /$ day for seven days compared to the high standard $0.5 \mathrm{mg} / \mathrm{kg} / \mathrm{day}$ for 14 days. There is probably no difference in frequency of recurrences between these two regimens. However one of these trials reported increased serious adverse events in the seven-day arm.

A difficulty encountered in including and comparing studies was the variation in dosing and length of follow-up in studies. In general, there were few well-conducted RCTs that used an evidence-based standard primaquine regimen $(0.25 \mathrm{mg} / \mathrm{kg} /$ day for 14 days $)$ as a comparator. Some trials used the high-standard $0.5 \mathrm{mg} / \mathrm{kg} / \mathrm{day}$ for 14 days regimen, which is recommended by the WHO in East Asia and Oceania, as a comparator. However, as noted above, there is limited clear evidence in this review that the high-standard $0.5 \mathrm{mg} /$ $\mathrm{kg} /$ day 14-day regimen is better than the standard $0.25 \mathrm{mg} / \mathrm{kg} /$ day for 14 days.

We found that trials continue to be conducted where placebo is used instead of an alternative primaquine regimen, which is contrary to the evidence available demonstrating its superiority for reducing recurrences (Galappaththy 2013). This may be because there is continued reluctance to use primaquine in some national programmes.

We excluded studies where individuals had mixed malaria infections so as to assess the efficacy of treatment on $P$ vivax malaria alone. Areas endemic for $P$ vivax malaria may also be coendemic for Plasmodium falciparum or Plasmodium ovale infection, or both. However, it should be noted that as part of our screening process we did not identify any studies where participants with mixed malaria were included, so we do not think that narrowing our search criteria impacted the directness of our results.

There was a lack of detailed safety data for some trials, despite the fact that safety is a particular concern with primaquine use. Although more recent trials have paid more attention to this issue, they do not all report the adverse events by arm.

\section{Certainty of the evidence}

The overall certainty of evidence for most of the outcomes was either low or very low. Most results were downgraded for

Primaquine alternative dosing schedules for preventing malaria relapse in people with Plasmodium vivax (Review) 
imprecision due to wide confidence intervals $(\mathrm{Cls})$ in the metaanalyses performed. The exception is the recent Comparison 4 using high dose $1 \mathrm{mg} / \mathrm{kg} /$ day versus high-standard course for the efficacy outcomes, where evidence for non-inferiority was moderate certainty.

The efficacy comparison for Comparison 2 (high-standard 14-day regimen versus the standard 14-day regimen) was also downgraded for indirectness. Results were based on two trials in adults in India (Rajgor 2014 IND; Saravu 2018 IND). Rajgor 2014 IND was at risk of bias as there was no allocation concealment and unexplained loss to follow-up; this study also contributed most to the metaanalysis for the comparison of $0.5 \mathrm{mg} / \mathrm{kg} /$ day for 7 days versus standard 14-day regimen, so this study was also downgraded. Saravu 2018 IND was a small pilot study where participants were given either chloroquine or an ACT for the blood stage, and which blood-stage treatment they were given was not stated by outcome (although appeared balanced between arms). Saravu 2018 IND was downgraded for imprecision, indirectness, and risk of bias (not blinded and high rate of loss to follow-up).

We downgraded the Comparison 3 of $0.75 \mathrm{mg} / \mathrm{kg}$ weekly primaquine versus high-standard 14-day regimen for indirectness as it was based on just one study conducted in Pakistan (Leslie 2008 PAK), with only one G6PD-deficient patient participating. Leslie 2008 PAK was at risk of bias due to the randomization process used, lack of allocation concealment, and incomplete outcome data. We downgraded efficacy outcomes for this comparison for serious imprecision due to few events and very wide Cls.

Comparison 4 of high-dose $1 \mathrm{mg} / \mathrm{kg}$ for seven days versus highstandard 14-day regimen was downgraded because one of the two trials was open-label (Chu 2019 THA).

\section{Potential biases in the review process}

The strictness of our inclusion criteria to not include trials where the total dose was less than the total dose of the standard regimen, and the necessity of having the comparison arm be one of the WHO-recommended regimens, may have meant that some relevant comparisons were excluded.

We changed the protocol to include the high-standard 14-day regimen that WHO recommends in East Asia and Oceania as a control regimen, as we realized that some trials had used this as the comparator, and we felt that these comparisons were useful. However, this may have introduced bias, as the evidence base for RCTs (including our results) showing the relative efficacy of this regimen is limited.

The difficulty in determining between relapse and re-infection with $P$ vivax remains a recognized challenge for assessing the efficacy of drugs for radical cure.

\section{Agreements and disagreements with other studies or reviews}

Three previous meta-analyses (John 2012; Carmona-Fonseca 2015; Zuluaga-Idarraga 2015) of this topic have been published. John 2012 did not explicitly compare short and long schedules, and none of the reviews included the recent high-dose $1 \mathrm{mg} / \mathrm{kg} /$ day sevenday course trials which are evaluated here.
Our findings that $210 \mathrm{mg}$ over seven days may be as efficacious as the standard course of $210 \mathrm{mg}$ over 14 days (Comparison 1 ) are consistent with findings of other systematic reviews that examined both randomized and non-randomized studies (Carmona-Fonseca 2015; Zuluaga-Idarraga 2015). The other reviews also confirm the lack of comparative evidence for the high-standard versus standard regimens (Comparison 2), whether in the recommended geographical area or not. However we included additional recent RCTs using the standard and high-standard schedules that were not included in Carmona-Fonseca 2015 or Zuluaga-Idarraga 2015. Only Carmona-Fonseca 2015 included weekly schedules, and like us identified only a single study (with one G6PD deficient participant) evaluating $0.75 \mathrm{mg} / \mathrm{kg} /$ day once a week for eight weeks compared to high-standard 14-day regimen (Comparison 3). Comparison 4 includes trials that are not in the other reviews.

Other reviews also commented on the difficulty of comparing results due to the varying treatment regimens and length of followup used in clinical trials.

The systematic review and individual patient data analysis of Commons 2019 showed that the adverse haematological effects of primaquine (when given with chloroquine) may be outweighed by the effect of preventing anaemia due to malaria relapses by day 42. We have not been able to investigate such a trade-off using the studies in this review.

\section{AUTHORS' CONCLUSIONS}

\section{Implications for practice}

Trials available to date do not detect a difference in efficacy between the regimen of $0.5 \mathrm{mg} / \mathrm{kg} /$ day for seven days and the standard $(0.25 \mathrm{mg} / \mathrm{kg} /$ day) 14-day regimen in G6PD-normal patients. Thus, clinicians wanting to prescribe a shorter regimen to improve treatment completion with the same as standard overall dose could use this regimen, and no serious adverse events were reported in G6PD-normal patients taking $0.5 \mathrm{mg} / \mathrm{kg} /$ day of primaquine for seven days. Clinicians considering the regimen of $1 \mathrm{mg} / \mathrm{kg} /$ day for seven days should take into account the elevated numbers of severe adverse events observed.

\section{Implications for research}

Further high-quality randomized controlled trials will help improve the certainty in different settings. Particularly useful would be studies of the $0.5 \mathrm{mg} / \mathrm{kg} /$ day seven-day and high-standard 14-day regimens in East Asia and Oceania (where the high standard course is current recommended), and studies testing modified or weekly regimens in G6PD-deficient patients.

\section{ACKN OWLEDGEMEN TS}

The Academic Editor is Professor Paul Garner.

We are grateful to Vittoria Lutje, Information Specialist of the Cochrane Infectious Diseases Group (CIDG), for help with the literature search strategy. We thank Marty Richardson, CIDG statistician, for help with the data collection and analysis strategy, and Paul Garner, CIDG Co-ordinating Editor, for help developing the research question and with data analysis.

We thank Cindy Chu and Ric Price for providing additional data from their trials Chu 2019 THA and Taylor 2019 MULTI. 
Rachael Milligan was supported by the Research, Evidence and Development Initiative (READ-It) project. READ-It and the CIDG editorial base are funded by UK aid from the UK government for the benefit of low- and middle-income countries (project number 300342-104). The views expressed do not necessarily reflect the UK government's official policies. 


\section{RE F E R E N C E S}

\section{References to studies included in this review}

Abdon 2001 BRA \{published data only\}

Abdon NP, Pinto AY, Silva RD, Souza JM. Assessment of the response to reduced treatment schemes for vivax malaria. Revista da Sociedade Brasileira de Medicina Tropical 2001;34(4):343-8.

\section{Bunnag 1994 THA \{published data only\}}

Bunnag D, Karbwang J, Thanavibul A, Chittamas S, Ratanapongse $\mathrm{Y}$, Chalermrut K, et al. High dose of primaquine in primaquine resistant vivax malaria. Transactions of the Royal Society of Tropical Medicine and Hygiene 1994;88(2):218-9.

\section{Carmona-Fonseca 2009 COL \{published data only\}}

Carmona-Fonseca J, Maestre A. Prevention of Plasmodium vivax malaria recurrence: efficacy of the standard total dose of primaquine administered over 3 days. Acta Tropica 2009;112(2):188-92.

\section{Chu 2019 THA \{published and unpublished data\}}

Chu C. Management of relapsing Plasmodium vivax malaria. International Journal of Infectious Diseases 2016;45:16. [DOI: 10.1016/j.ijid.2016.02.070]

* Chu CS, Phyo AP, Turner C, Win HH, Poe NP, Yotyingaphiram W, et al. Chloroquine versus dihydroartemisinin-piperaquine with standard high-dose primaquine given either for 7 days or 14 days in Plasmodium vivax malaria. Clinical Infectious Diseases 2019;68(8):1311-9.

\section{Durand 2014 PER \{published data only\}}

Durand S, Cabezas C, Lescano AG, Galvez M, Gutierrez S, Arrospide N, et al. Efficacy of three different regimens of primaquine for the prevention of relapses of Plasmodium vivax malaria in the Amazon Basin of Peru. American Journal of Tropical Medicine and Hygiene 2014;91(1):18-26.

\section{Leslie 2008 PAK \{published data only\}}

Leslie T, Mayan I, Mohammed N, Erasmus P, Kolaczinski J, Whitty $\mathrm{CJ}$, et al. A randomised trial of an eight-week, once weekly primaquine regimen to prevent relapse of Plasmodium vivax in Northwest Frontier Province, Pakistan. PLOS One 2008;3(8):e2861.

\section{Pareek 2015 IND \{published data only\}}

Pareek A, Chandurkar N, Gogtay N, Deshpande A, Kakrani A, Kaneria $\mathrm{M}$, et al. Sustained release formulation of primaquine for prevention of relapse of Plasmodium vivax malaria: a randomized, double-blind, comparative, multicentric study. Malaria Research and Treatment 2015;2015:579864.

\section{Rajgor 2014 IND \{published data only\}}

Rajgor DD, Gogtay NJ, Kadam VS, Kocharekar MM, Parulekar MS, Dalvi SS, et al. Antirelapse efficacy of various primaquine regimens for Plasmodium vivax. Malaria Research and Treatment 2014;2014:347018.

\section{Saravu 2018 IND \{published data only\}}

Saravu K, Tellapragada C, Kulavalli S, Xavier W, Umakanth S, Brahmarouphu G, et al. A pilot randomized controlled trial to compare the effectiveness of two 14-day primaquine regimens for the radical cure of vivax malaria in South India. Malaria Journal 2018;17:321.

\section{Solari-Soto 2002 PER \{published data only\}}

Solari Soto L, Soto Tarazona AR, Mendoza Requena D, Llanos Cuentas EA. Clinical trial of the treatment of vivax malaria with shortened primaquine scheme compared to the traditional scheme [Ensayo clínico del tratamiento de la malaria vivax con esquema acortado de primaquina comparado con el esquema tradicional]. Revista de la Sociedad Peruana de Medicina Interna 2002;15(4):197-9.

\section{Taylor 2019 MULTI \{published and unpublished data\}} IMPROV Study Group. Improving the radical cure of vivax malaria (IMPROV): a study protocol for a multicentre randomised, placebo-controlled comparison of short and long course primaquine regimens. BMC Infectious Diseases 2015;15:558. [DOI: 10.1186/s12879-015-1276-2]

NCT01814683. IMPROV (Improving the radical cure of vivax malaria) [Improving the radical cure of vivax malaria: a multicentre randomised comparison of short and long course primaquine regimens]. clinicaltrials.gov/ct2/show/ NCT01814683 (first posted 20 March 2013).

* Taylor WR, Thriemer K, von Seidlein L, Yuentrakul P, Assawariyathipat T, Assefa A, et al. Short-course primaquine for the radical cure of Plasmodium vivax malaria: a multicentre, randomised, placebo-controlled non-inferiority trial. Lancet 2019;394(10202):929-38.

\section{References to studies excluded from this review}

\section{Adak 2001 \{published data only\}}

Adak T, Valecha N, Sharma VP. Plasmodium vivax polymorphism in a clinical drug trial. Clinical \& Diagnostic Laboratory Immunology 2001;8(5):891-4.

\section{Alvarez 2006 \{published data only\}}

Alvarez G, Pineros JG, Tobon A, Rios A, Maestre A, Blair S, et al. Efficacy of three chloroquine-primaquine regimens for treatment of Plasmodium vivax malaria in Colombia. American Journal of Tropical Medicine and Hygiene 2006;75(4):605-9.

\section{Alvarez Sanchez 2007 \{published data only\}}

Álvarez Sánchez LG, Piñeros Jimenez JG, Tobón Castaño A, Ríos Orrego AM, Maestre Buitrago AE, Blair Trujillo S, et al. Efficacy of three chloroquine-primaquine regimens for treatment of Plasmodium vivax malaria in Colombia [Eficacia de tres esquemas con cloroquina - primaquina para el tratamiento de la malaria por Plasmodium vivax en Colombia]. CES Medicine 2007;21(2):51-60. 
Betuela 2012 \{published data only\}

Betuela I, Bassat Q, Kiniboro B, Robinson LJ, Rosanas-Urgell A, Stanisic $D$, et al. Tolerability and safety of primaquine in Papua New Guinean children 1 to 10 years of age. Antimicrobial Agents and Chemotherapy 2012;4:2146-9.

\section{Chu 2017 \{published data only\}}

Chu CS, Bancone G, Moore KA, Win HH, Thitipanawan N, Po C, et al. Haemolysis in G6PD heterozygous females treated with primaquine for Plasmodium vivax malaria: a nested cohort in a trial of radical curative regimens. PLOS Medicine 2017;14(2):e1002224.

\section{Chu 2018 \{published data only\}}

Chu CS, Phyo AP, Lwin KM, Win HH, San T, Aung AA, et al. Comparison of the cumulative efficacy and safety of chloroquine, artesunate, and chloroquine-primaquine in Plasmodium vivax malaria. Clinical Infectious Diseases 2018;67(10):1543-9.

\section{Clyde 1977 \{published data only\}}

Clyde DF, McCarthy VC. Radical cure of Chesson strain vivax malaria in man by 7 , not 14 , days of treatment with primaquine. American Journal of Tropical Medicine and Hygiene 1977;26(3):562-3.

\section{Contacos 1974 \{published data only\}}

Contacos PG, Collins WE, Chin W, Jeter MH, Briesch PE. Combined chloroquine-primaquine therapy against vivax malaria. American Journal of Tropical Medicine and Hygiene 1974;23(2):310-2.

\section{Daher 2018 \{published data only\}}

Daher A, Pereira D, Lacerda MV, Alexandre MA, Nascimento CT, Alves de Lima e Silva JC, et al. Efficacy and safety of artemisininbased combination therapy and chloroquine with concomitant primaquine to treat Plasmodium vivax malaria in Brazil: an open label randomized clinical trial. Malaria Journal 2018;17(1):45.

\section{da Silva 1984 \{published data only\}}

da Silva AR, Carneiro EW, dos Santos HJ. Response of human Plasmodium to antimalarials on the Island of Saint Louis, State of Maranhão, Brazil. Revista do Instituto de Medicina Tropical de São Paulo 1984;26(3):139.

\section{Gogtay 1999 \{published data only\}}

Gogtay NJ, Desai S, Kamtekar KD, Kadam VS, Dalvi SS, Kshirsagar NA. Efficacies of 5- and 14-day primaquine regimens in the prevention of relapses in Plasmodium vivax infections. Annals of Tropical Medicine \& Parasitology 1999;93(8):809-12.

\section{Goller 2007 \{published data only\}}

Goller JL, Jolley D, Ringwald P, Biggs BA. Regional differences in the response of Plasmodium vivax malaria to primaquine as anti-relapse therapy. American Journal of Tropical Medicine and Hygiene 2007;76(2):203-7.

\section{Hamid 2018 \{published data only\}}

Hamid MM, Thriemer K, Elobied ME, Mahgoub NS, Boshara SA, Elsafi HM, et al. Low risk of recurrence following artesunate-
Sulphadoxine-pyrimethamine plus primaquine for uncomplicated Plasmodium falciparum and Plasmodium vivax infections in the Republic of the Sudan. Malaria Journal 2018;17(1):117.

Kim 2012 \{published data only\}

Kim JR, Nandy A, Maji AK, Addy M, Dondorp AM, Day NP, et al. Genotyping of Plasmodium vivax reveals both short and long latency relapse patterns in Kolkata. PLOS One 2012;7(7):e39645.

Kimura 1996 \{published data only\}

Kimura M, Tomizawa I, Takizawa Y, Ohtomo H. A study of relapsed cases of vivax malaria after the standard primaquine therapy. Kansenshogaku Zasshi. Journal of the Japanese Association for Infectious Diseases 1996;70(10):1086-91.

Krudsood 2008 \{published data only\}

Krudsood S, Tangpukdee N, Wilairatana P, Phophak N, Baird JK, Brittenham GM, et al. High-dose primaquine regimens against relapse of Plasmodium vivax malaria. American Journal of Tropical Medicine and Hygiene 2008;78(5):736-40.

Ladeia-Andrade 2019 \{published data only\} Ladeia-Andrade S, Menezes MJ, de Sousa TN, Silvino AC, de Carvalho JF Jr, Salla LC, et al. Monitoring the efficacy of chloroquine-primaquine therapy for uncomplicated Plasmodium vivax malaria in the main transmission hot spot of Brazil. Antimicrobial Agents and Chemotherapy 2019;63(5):pii: e01965-18.

\section{Leslie 2004 \{published data only\}}

Leslie T, Rab MA, Ahmadzai H, Durrani N, Fayaz M, Kolaczinski J, et al. Compliance with 14-day primaquine therapy for radical cure of vivax malaria - a randomized placebo-controlled trial comparing unsupervised with supervised treatment. Transactions of the Royal Society of Tropical Medicine and Hygiene 2004;98(3):168-73.

\section{Leslie 2008b \{published data only\}}

Leslie T, Mayan I, Mohammed N, Erasmus P, Kolaczinski J, Whitty CJ. Abstract 337: A randomised trial of an eight-week, once weekly primaquine regimen to prevent relapse of Plasmodium vivax in Pakistan. American Journal of Tropical Medicine and Hygiene 2008;Suppl 6:120.

\section{Maneeboonyang 2011 \{published data only\}}

Maneeboonyang W, Lawpoolsri S, Puangsa-art S, Yimsamran S, Thanyavanich N, Wuthisen P, et al. Directly observed therapy with primaquine to reduce the recurrence rate of Plasmodium vivax infection along the Thai-Myanmar border. Southeast Asian Journal of Tropical Medicine and Public Health 2011;42(1):9.

\section{Miller 1974 \{published data only\}}

Miller LH, Wyler DJ, Glew RH, Collins WE, Contacos PG. Sensitivity of four Central American strains of Plasmodium vivax to primaquine. American Journal of Tropical Medicine and Hygiene 1974;23(2):309-10.

Moore 2018 \{published data only\}

Moore BR, Tobe R, Laman M, Benjamin J, Salman S, Mueller I, et al. Safety, tolerability, efficacy and pharmacokinetics of high 
dose, short course primaquine regimens in Papua New Guinean children. American Journal of Tropical Medicine and Hygiene 2018;99(4 Supplement):25.

\section{Pasaribu 2013 \{published data only\}}

Pasaribu AP, Chokejindachai W, Sirivichayakul C, Tanomsing N, Chavez I, Tjitra E, et al. A randomized comparison of dihydroartemisinin-piperaquine and artesunate-amodiaquine combined with primaquine for radical treatment of vivax malaria in Sumatera, Indonesia. Journal of Infectious Diseases 2013;208(11):1906-13.

\section{Pukrittayakamee 2000 \{published data only\}}

Pukrittayakamee S, Chantra A, Simpson JA, Vanijanonta S, Clemens R, Looareesuwan S, et al. Therapeutic responses to different antimalarial drugs in vivax malaria. Antimicrobial Agents and Chemotherapy 2000;44(6):1680-5.

\section{Sabchareon 1981 \{published data only\}}

Sabchareon A, Chongsuphajaisiddhi T. Initial response to single-dose of chloroquine, sulfadoxine-pyrimethamine and primaquine in children with vivax malaria. Southeast Asian Journal of Tropical Medicine and Public Health 1981;3:443-4.

\section{Saint-Yves IF 1977 \{published data only\}}

Saint-Yves IF. Comparison of treatment schedules for Plasmodium vivax infections in the Solomon Islands. Papua and New Guinea Medical Journal 1977;20(2):62-5.

\section{Takeuchi 2010 \{published data only\}}

Takeuchi R, Lawpoolsri S, Imwong M, Kobayashi J, Kaewkungwal J, Pukrittayakamee S, et al. Directly-observed therapy (DOT) for the radical 14-day primaquine treatment of Plasmodium vivax malaria on the Thai-Myanmar border. Malaria Journal 2010;9(1):308.

\section{Villalobos-Salcedo 2000 \{published data only\}}

Villalobos-Salcedo JM, Tada MS, Kimura E, Menezes MJ, Pereirada-Silva LH. In-vivo sensitivity of Plasmodium vivax isolates from Rondonia (western Amazon region, Brazil) to regimens including chloroquine and primaquine. Annals of Tropical Medicine \& Parasitology 2000;94(8):749-58.

\section{Warrasak 2019 \{published data only\}}

Warrasak S, Euswas A, Fukuda MM, Ittiverakul M, Miller RS, Krudsood S, et al. Comparative ophthalmic assessment of patients receiving tafenoquine or chloroquine/primaquine in a randomized clinical trial for Plasmodium vivax malaria radical cure. International Ophthalmology 2019;39(8):1767-82. [DOI: 10.1007/s10792-018-1003-2]

\section{References to ongoing studies \\ NCT01837992 \{unpublished data only\}}

NCT01837992. Safety and efficacy of primaquine for P. vivax [Evaluation of safety and efficacy of two primaquine dosing regimens for the radical treatment of Plasmodium vivax malaria in Vanuatu and Solomon Islands]. clinicaltrials.gov/ct2/show/ NCT01837992 (first posted 23 April 2013).

\section{Additional references}

\section{Arévalo-Herrera 2015}

Arévalo-Herrera M, Lopez-Perez M, Medina L, Moreno A, Gutierrez JB, Herrera S. Clinical profile of Plasmodium falciparum and Plasmodium vivax infections in low and unstable malaria transmission settings of Colombia. Malaria Journal 2015;14:154.

\section{Ashley 2014}

Ashley EA, Recht J, White NJ. Primaquine: the risks and the benefits. Malaria Journal 2014;13:418.

\section{Baird 2003}

Baird JK, Rieckmann KH. Can primaquine therapy for vivax malaria be improved? Trends in Parasitology 2003;19(3):115-20.

\section{Baird 2004}

Baird JK, Hoffman SL. Primaquine therapy for malaria. Clinical Infectious Diseases 2004;39(9):1336-45.

\section{Baird 2013}

Baird JK. Evidence and implications of mortality associated with acute Plasmodium vivax malaria. Clinical Microbiology Reviews 2013;26(1):36-57.

\section{Baird 2015a}

Baird JK. Origins and implications of neglect of G6PD deficiency and primaquine toxicity in Plasmodium vivax malaria. Pathogens and Global Health 2015;109(3):93-106.

\section{Baird 2015b}

Baird JK. Point-of-care G6PD diagnostics for Plasmodium vivax malaria is a clinical and public health urgency. BMC Medicine 2015;13:296.

\section{Baird 2018}

Baird JK, Louisa M, Noviyanti R, Ekawati L, Elyazar I, Subekti D, et al. Association of impaired cytochrome P450 2D6 activity genotype and phenotype with therapeutic efficacy of primaquine treatment for latent Plasmodium vivax malaria. JAMA Network Open 2018;1(4):e181449.

\section{Bassat 2016}

Bassat Q, Velarde M, Mueller I, Lin J, Leslie T, Wongsrichanalai C, et al. Key knowledge gaps for Plasmodium vivax control and elimination. American Journal of Tropical Medicine and Hygiene 2016;95(6 Suppl):62-71.

\section{Battle 2014}

Battle KE, Karhunen MS, Bhatt S, Gething PW, Howes RE, Golding N, et al. Geographical variation in Plasmodium vivax relapse. Malaria Journal 2014;13:144.

\section{Bennett 2013}

Bennett JW, Pybus BS, Yadava A, Tosh D, Sousa JC, McCarthy WF, et al. Primaquine failure and cytochrome P-450 2D6 in Plasmodium vivax malaria. New England Journal of Medicine 2013;369(14):1381-2. 


\section{Bhattacharjee 2013}

Bhattacharjee P, Dubey S, Gupta VK, Agarwal P, Mahato MP. The clinicopathologic manifestations of Plasmodium vivax malaria in children: a growing menace. Journal of Clinical and Diagnostic Research 2013;7(5):861-7.

\section{Brutus 2013}

Brutus L, Santalla J, Schneider D, Avila JC, Deloron P. Plasmodium vivax malaria during pregnancy, Bolivia. Emerging Infectious Diseases 2013;19(10):1605-11.

\section{Carmona-Fonseca 2015}

Carmona-Fonseca J. Primaquine and relapses of Plasmodium vivax. Meta analysis of controlled clinical trials. Revista Brasileira de Epidemiologia 2015;18(1):174-93.

\section{Cheng 2015}

Cheng Q, Cunningham J, Gatton ML. Systematic review of submicroscopic $P$. vivax infections: prevalence and determining factors. PLOS Neglected Tropical Diseases 2015;9(1):e3413.

\section{Cibulskis 2015}

Cibulskis R. Plasmodium vivax: a roadblock on the quest to eliminate malaria. Lancet Infectious Diseases 2015;15(10):1127-8.

\section{Coatney 1953}

Coatney GR, Alving AS, Jones R Jr, Hankey DD, Robinson DH, Garrison PL, et al. Korean vivax malaria. V. Cure of the infection by primaquine administered during long-term latency. American Journal of Tropical Medicine and Hygiene 1953;2(6):985-8.

\section{Commons 2019}

Commons RJ , Simpson JA, Thriemer K, Chu CS, Douglas NM, Abreha T, et al. The haematological consequences of Plasmodium vivax malaria after chloroquine treatment with and without primaquine: a WorldWide Antimalarial Resistance Network systematic review and individual patient data meta-analysis. BMC Medicine 2019;17(1):151. [DOI: https:// doi.org/10.1186/s12916-019-1386-6]

\section{Douglas 2014}

Douglas NM, Pontororing GJ, Lampah DA, Yeo TW, Kenangalem E, Poespoprodjo JR, et al. Mortality attributable to Plasmodium vivax malaria: a clinical audit from Papua, Indonesia. BMC Medicine 2014;12:217.

\section{Ehrman 1945}

Ehrman FC, Ellis JM, Young MD. Plasmodium vivax Chesson strain. Science 1945;101(2624):377.

\section{Galappaththy 2013}

Galappaththy GN, Tharyan P, Kirubakaran R. Primaquine for preventing relapse in people with Plasmodium vivax malaria treated with chloroquine. Cochrane Database of Systematic Reviews 2013, Issue 10. Art. No: CD004389. [DOI: 10.1002/14651858.CD004389.pub3]

\section{Gething 2012}

Gething PW, Elyazar IR, Moyes CL, Smith DL, Battle KE, Guerra CA, et al. A long neglected world malaria map: Plasmodium vivax endemicity in 2010. PLOS Neglected Tropical Diseases 2012;6(9):e1814.

\section{Gilder 2018}

Gilder ME, Hanpithakphong W, Hoglund RM, Tarning J, Win HH, Hilda N, et al. Primaquine pharmacokinetics in lactating women and breastfed infant exposures. Clinical Infectious Diseases 2018;86:1000-7.

\section{Gogtay 2013}

Gogtay N, Kannan S, Thatte UM, Olliaro PL, Sinclair D. Artemisinin-based combination therapy for treating uncomplicated Plasmodium vivax malaria. Cochrane Database of Systematic Reviews 2013, Issue 10. Art. No: CD008492. [DOI: 10.1002/14651858.CD008492.pub3]

\section{GRADEpro GDT 2015 [Computer program]}

McMaster University (developed by Evidence Prime) GRADEpro GDT. Version accessed 19 April 2017. Hamilton (ON): McMaster University (developed by Evidence Prime), 2015. Available at gradepro.org.

\section{Graves 2018}

Graves P, Choi L, Gelband H, Garner P. Primaquine or other 8-aminoquinolines for reducing Plasmodium falciparum transmission. Cochrane Database of Systematic Reviews 2018, Issue 2. Art. No: CD008152. [DOI: 10.1002/14651858.CD008152.pub5]

\section{Grietens 2010}

Grietens KP, Soto V, Erhart A, Ribera JM, Toomer E, Tenorio A, et al. Adherence to 7-day primaquine treatment for the radical cure of P. vivax in the Peruvian Amazon. American Journal of Tropical Medicine and Hygiene 2010;82(6):1017-23.

\section{Higgins 2011}

Higgins JP, Green S, editor(s). Cochrane Handbook for Systematic Reviews of Interventions Version 5.1.0 (updated March 2011). The Cochrane Collaboration, 2011. Available from handbook.cochrane.org.

\section{Howes 2012}

Howes RE, Piel FB, Patil AP, Nyangiri OA, Gething PW, Dewi M, et al. G6PD deficiency prevalence and estimates of affected populations in malaria endemic countries: a geostatistical model-based map. PLOS Medicine 2012;9(11):e1001339.

\section{Howes 2016}

Howes RE, Battle KE, Mendis KN, Smith DL, Cibulskis RE, Baird JK, et al. Global epidemiology of Plasmodium vivax. American Journal of Tropical Medicine and Hygiene 2016;95(6):15-34.

\section{Imwong 2007}

Imwong M, Snounou G, Pukrittayakamee S, Tanomsing N, Kim JR, Nandy A, et al. Relapses of Plasmodium vivax infection usually result from activation of heterologous hypnozoites. Journal of Infectious Diseases 2007;195(7):927-33. 


\section{John 2012}

John GK, Douglas NM, von Seidlein L, Nosten F, Baird JK, White NJ, et al. Primaquine radical cure of Plasmodium vivax: a critical review of the literature. Malaria Journal 2012;11:280.

\section{Jones 1953}

Jones R Jr, Jackson LS, Di Lorenzo A, Marx RL, Levy BL, Kenny EC, et al. Korean vivax malaria. IV. Curative effect of 15 milligrams of primaquine daily for 7 days. American Journal of Tropical Medicine and Hygiene 1953;2(6):977-82.

\section{Kochar 2014}

Kochar DK, Das A, Kochar A, Middha S, Acharya J, Tanwar GS, et al. A prospective study on adult patients of severe malaria caused by Plasmodium falciparum, Plasmodium vivax and mixed infection from Bikaner, northwest India. Journal of Vector Borne Diseases 2014;51(3):200-10.

\section{Koepfli 2015}

Koepfli C, Rodrigues PT, Antao T, Orjuela-Sánchez P, Van den Eede P, Gamboa D, et al. Plasmodium vivax diversity and population structure across four continents. PLOS Neglected Tropical Diseases 2015;9(6):e0003872.

\section{Kumar 2007}

Kumar A, Valecha N, Jain T, Dash AP. Burden of malaria in India: retrospective and prospective view. American Journal of Tropical Medicine and Hygiene 2007;77(6 Suppl):69-78.

\section{Looareesuwan 1997}

Looareesuwan S, Buchachart K, Wilairatana P, Chalermrut K, Rattanapong Y, Amradee S, et al. Primaquine-tolerant vivax malaria in Thailand. Annals of Tropical Medicine and Hygiene 1997;91(8):939-43.

\section{Maffi 1971}

Maffi M, McDonnell M. Malaria in the Eastern Outer Islands, British Solomon Islands protectorate. Parassitologia 1971;13(3):455-503.

\section{McGready 2012}

McGready R, Lee S, Wiladphaingern J, Ashley E, Rijken M, Boel M, et al. Adverse effects of falciparum and vivax malaria and the safety of antimalarial treatment in early pregnancy: a population-based study. Lancet Infectious Diseases 2012;12(5):388-96.

\section{Mendis 2001}

Mendis K, Sina BJ, Marchesini P, Carter R. The neglected burden of Plasmodium vivax malaria. American Journal of Tropical Medicine and Hygiene 2001;64(1-2 Suppl):97-106.

\section{Mikolajczak 2015}

Mikolajczak SA, Vaughan AM, Kangwanrangsan N, Roobsoong W, Fishbaugher M, Yimamnuaychok N, et al. Plasmodium vivax liver stage development and hypnozoite persistence in human liver-chimeric mice. Cell Host \& Microbe 2015;17(4):526-35.

\section{2018}

Medicines for Malaria Venture. US FDA approves Krintafel (tafenoquine) for the radical cure of P. vivax malaria. www.mmv.org/newsroom/press-releases/us-fda-approveskrintafel-tafenoquine-radical-cure-p-vivax-malaria (accessed 24 July 2018).

\section{Mueller 2009}

Mueller I, Galinski MR, Baird JK, Carlton JM, Kochar DK, Alonso PL, et al. Key gaps in the knowledge of Plasmodium vivax, a neglected human malaria parasite. Lancet Infectious Diseases 2009;9(9):555-66.

\section{Newby 2016}

Newby G, Bennett A, Larson E, Cotter C, Shretta R, Phillips AA et al. The path to eradication: a progress report on the malariaeliminating countries. Lancet 2016;387(10029):1775-84.

\section{Nkhoma 2009}

Nkhoma ET, Poole C, Vannappagari V, Hall SA, Beutler E. The global prevalence of glucose-6-phosphate dehydrogenase deficiency: a systematic review and meta-analysis. Blood Cells, Molecules, and Diseases 2009;42(3):267-78.

\section{Rajapakse 2015}

Rajapakse S, Rodrigo C, Fernando SD. Tafenoquine for preventing relapse in people with Plasmodium vivax malaria. Cochrane Database of Systematic Reviews 2015, Issue 4. Art. No: CD010458. [DOI: 10.1002/14651858.CD010458.pub2]

\section{Review Manager 2014 [Computer program]}

Nordic Cochrane Centre, The Cochrane Collaboration Review Manager 5 (RevMan 5). Version 5.3. Copenhagen: Nordic Cochrane Centre, The Cochrane Collaboration, 2014.

\section{Rijken 2012}

Rijken MJ, McGready R, Boel ME, Poespoprodjo R, Singh N, Syafruddin D, et al. Malaria in pregnancy in the Asia-Pacific region. Lancet Infectious Diseases 2012;12(1):75-88.

\section{Rizvi 2013}

Rizvi I, Tripathi DK, Chughtai AM, Beg M, Zaman S, Zaidi N. Complications associated with Plasmodium vivax malaria: a retrospective study from a tertiary care hospital based in western Uttar Pradesh, India. Annals of African Medicine 2013;12(3):155-9.

\section{Robinson 2015}

Robinson LJ, Wampfler R, Betuela I, Karl S, White MT, Li Wai Suen CS, et al. Strategies for understanding and reducing the Plasmodium vivax and Plasmodium ovale hypnozoite reservoir in Papua New Guinean children: a randomised placebocontrolled trial and mathematical model. PLOS Medicine 2015;12(10):e1001891.

\section{Saint-Yves 1977}

Saint-Yves IFM. Comparison of treatment schedules for Plasmodium vivax infections in the Solomon Islands. Papua and New Guinea Medical Journal 1977;20(2):62-5. 


\section{Schmidt 1977}

Schmidt LH, Fradkin R, Vaughan D, Rasco J. Radical cure of infections with Plasmodium cynomolgi: a function of total 8aminoquinoline dose. American Journal of Tropical Medicine and Hygiene 1977;26(6 Pt 1):1116-28.

\section{Singh 2013}

Singh J, Purohit B, Desai A, Savardekar L, Shanbag P, Kshirsagar N. Clinical manifestations, treatment, and outcome of hospitalized patients with Plasmodium vivax malaria in two Indian States: a retrospective study. Malaria Research and Treatment 2013;2013:341862.

\section{Sutanto 2013}

Sutanto I, Tjahjono B, Basri H, Taylor WR, Putri FA, Meilia RA, et al. Randomized, open-label trial of primaquine against vivax malaria relapse in Indonesia. Antimicrobial Agents and Chemotherapy 2013;57(3):1128-35.

\section{Valdes 2018}

Valdes A, Epelboin L, Mosnier E, Walter G, Vesin G, Abboud P, at al. Primaquine $30 \mathrm{mg} /$ day versus $15 \mathrm{mg}$ /day during 14 days for the prevention of Plasmodium vivax relapses in adults in French Guiana: a historical comparison. Malaria Journal 2018;17:237.

\section{Vale 2009}

Vale N, Moreira R, Gomes P. Primaquine revisited six decades after its discovery. European Journal of Medicinal Chemistry 2009;44(3):937-53.

\section{Vivona 1961}

Vivona S, Brewer GJ, Conrad M, Alving AS. The concurrent weekly administration of chloroquine and primaquine for the prevention of Korean vivax malaria. Bulletin of the World Health Organization 1961;25:267-9.

\section{White 2011}

White NJ. Determinants of relapse periodicity in Plasmodium vivax malaria. Malaria Journal 2011;10:297.

\section{White 2016}

White MT, Shirreff G, Karl S, Ghani AC, Mueller I. Variation in relapse frequency and the transmission potential of Plasmodium vivax malaria. Proceedings of the Royal Society $B$ 2016;283(1827):20160048.

\section{WHO 2009}

World Health Organization. Methods for surveillance of antimalarial drug efficacy. www.who.int/iris/ handle/10665/44048 (accessed prior to 14 May 2019).

\section{WHO 2015}

World Health Organization. Guidelines for the Treatment of Malaria. 3rd edition. Geneva: World Health Organization, 2015.

\section{WHO 2016}

World Health Organization. Eliminating malaria. apps.who.int/iris/bitstream/10665/205565/1/ WHO_HTM_GMP_2016.3_eng.pdf (accessed prior to 14 May 2019).

\section{WHO 2017}

World Health Organization. World malaria report 2017. apps.who.int/iris/bitstream/ handle/10665/259492/9789241565523-eng.pdf (accessed prior to 14 May 2019).

\section{WHO 2019}

World Health Organization. World malaria report 2019. www.who.int/publications-detail/world-malaria-report-2019 (accessed 26 March 2020).

\section{Zuluaga-Idarraga 2015}

Zuluaga-Idarraga LM, Tamayo Perez ME, Aguirre-Acevedo DC. Therapeutic efficacy of alternative primaquine regimens to standard treatment in preventing relapses by Plasmodium vivax: a systematic review and meta-analysis. Colombia Médica 2015;46(4):183-91.

\section{References to other published versions of this review Milligan 2017}

Milligan R, Daher A, Graves PM. Primaquine at alternative dosing schedules for preventing relapse in people with Plasmodium vivax malaria. Cochrane Database of Systematic Reviews 2017, Issue 5. Art. No: CD012656. [DOI: 10.1002/14651858.CD012656]

\section{Milligan 2019}

Milligan R, Daher A, Graves PM. Primaquine at alternative dosing schedules for preventing relapse in people with Plasmodium vivax malaria. Cochrane Database of Systematic Reviews 2019, Issue 7. Art. No: CD012656. [DOI: 10.1002/14651858.CD012656.pub2]

* Indicates the major publication for the study

\section{CHARACTERISTICS OF STUDIES}

Characteristics of included studies [ordered by study ID]

Abdon 2001 BRA

\section{Study characteristics}

Methods $\quad$ RCT

Primaquine alternative dosing schedules for preventing malaria relapse in people with Plasmodium vivax (Review) 
Abdon 2001 BRA (Continued)

July 1994 to June 1995

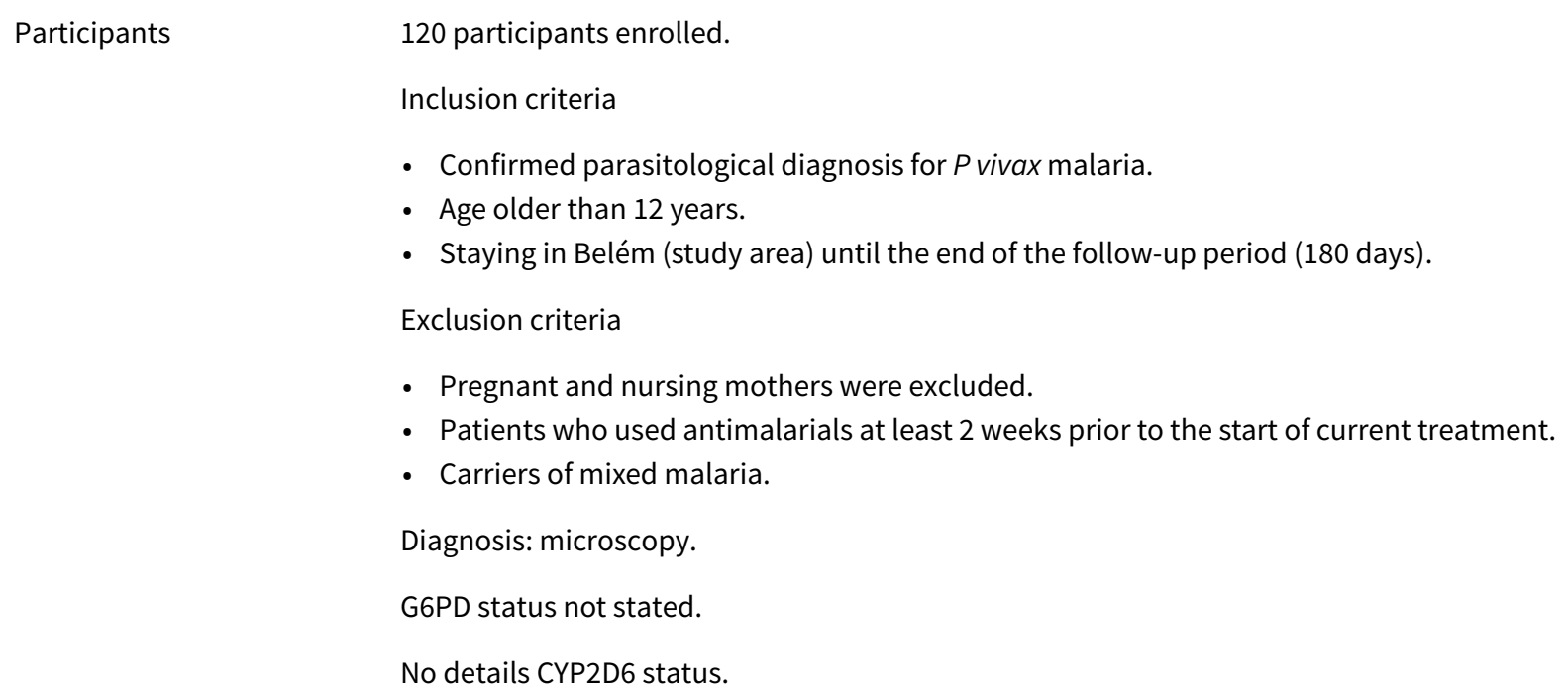

- Chloroquine $10 \mathrm{mg} / \mathrm{kg}$ single dose + primaquine $0.5 \mathrm{mg} / \mathrm{kg} /$ day for 7 days.

- Chloroquine $150 \mathrm{mg}$ (25 mg/kg total dose) over 3 days, $10 \mathrm{mg} / \mathrm{kg}$ day $1,7.5 \mathrm{mg} / \mathrm{kg}$ days 2 and $3+$ primaquine $15 \mathrm{mg} /$ day 14 days.

(Additional arm chloroquine $10 \mathrm{mg} / \mathrm{kg}$ + primaquine $0.5 \mathrm{mg} / \mathrm{kg}$ for 5 days not included as total dose (150 mg) less than standard treatment $(210 \mathrm{mg})$ )

Although different doses of chloroquine in the 2 arms, all participants had negative parasitaemia within 72 hours.

Primaquine and chloroquine given concurrently.

Supervised treatment.

\begin{tabular}{|c|c|c|}
\hline \multirow{2}{*}{$\begin{array}{l}\text { Outcomes } \\
\text { Notes }\end{array}$} & \multicolumn{2}{|l|}{$\begin{array}{l}\text { - Relapse } \\
\text { - Safety } \\
\text { Follow-up } 180 \text { days }\end{array}$} \\
\hline & $\begin{array}{l}\text { Location: Belém, state } \\
\text { Setting: not stated } \\
\text { Source of funding: not }\end{array}$ & $\begin{array}{l}\text { ff Pará, Brazil } \\
\text { tated }\end{array}$ \\
\hline \multicolumn{3}{|l|}{ Risk of bias } \\
\hline Bias & Authors' judgement & Support for judgement \\
\hline $\begin{array}{l}\text { Random sequence genera- } \\
\text { tion (selection bias) }\end{array}$ & Unclear risk & No details supplied on randomization process. \\
\hline $\begin{array}{l}\text { Allocation concealment } \\
\text { (selection bias) }\end{array}$ & Unclear risk & No details supplied on allocation. \\
\hline $\begin{array}{l}\text { Blinding of participants } \\
\text { and personnel (perfor- } \\
\text { mance bias) } \\
\text { All outcomes }\end{array}$ & High risk & Open-label. \\
\hline
\end{tabular}


Abdon 2001 BRA (Continued)
Blinding of outcome as-
High risk
Open-label. sessment (detection bias)

All outcomes

Incomplete outcome data Low risk $\quad$ One loss to follow-up as moved out of area.
(attrition bias)

All outcomes

\begin{tabular}{|c|c|c|}
\hline $\begin{array}{l}\text { Selective reporting (re- } \\
\text { porting bias) }\end{array}$ & Low risk & $\begin{array}{l}\text { Unable to find protocol but relapse and standard errors (SEs) reported as } \\
\text { would be expected. }\end{array}$ \\
\hline
\end{tabular}

Other bias Unclear risk $\quad$ Funding not stated.

\section{Bunnag 1994 THA}

\section{Study characteristics}

\begin{tabular}{ll}
\hline Methods & RCT \\
& Dates not provided \\
\hline Participants & 167 participants enrolled. \\
Inclusion criteria \\
- 15 to 60 years. \\
Exclusion criteria \\
- History of previous treatment. \\
- G6PD deficiency. \\
Dixed infections. \\
No details on pregnant/breastfeeding women. \\
No details CYP2D6 status.
\end{tabular}

Interventions

- Chloroquine $+22.5 \mathrm{mg} /$ day primaquine for 14 days .

- Chloroquine $+15 \mathrm{mg} /$ day primaquine for 14 days.

Open randomization to chloroquine treatment - either $300 \mathrm{mg}$ or $450 \mathrm{mg}$ on day 1 of admission. Re-allocated after recovery of acute symptoms (double-blind RCT). Chloroquine course completed and parasitological clearance confirmed prior to randomization to primaquine group (exact time between treatment courses not specified).

Supervised treatment in hospital.

\begin{tabular}{ll}
\hline Outcomes & Relapse \\
& Follow-up 6 months \\
\hline Notes & Location: Thailand \\
& Setting: not stated
\end{tabular}


Bunnag 1994 THA (Continued)

Funding: not stated

\section{Risk of bias}

\begin{tabular}{lll}
\hline Bias & Authors' judgement & Support for judgement \\
\hline $\begin{array}{l}\text { Random sequence genera- } \\
\text { tion (selection bias) }\end{array}$ & Unclear risk & $\begin{array}{l}\text { 1st step chloroquine is open randomization, then PQ stage randomized. No de- } \\
\text { tails on randomization process. }\end{array}$ \\
\hline $\begin{array}{l}\text { Allocation concealment } \\
\text { (selection bias) }\end{array}$ & Unclear risk & No details. \\
\hline $\begin{array}{l}\text { Blinding of participants } \\
\text { and personnel (perfor- } \\
\text { mance bias) }\end{array}$ & Low risk & Reported as double-blind. \\
All outcomes & \\
\hline $\begin{array}{l}\text { Blinding of outcome as- } \\
\text { sessment (detection bias) } \\
\text { All outcomes }\end{array}$ & Unclear risk & $\begin{array}{l}\text { Reported as double-blind but there were no details as to whether microscopy } \\
\text { was blinded or whether there was double reading of smears. }\end{array}$ \\
\hline $\begin{array}{l}\text { Incomplete outcome data } \\
\text { (attrition bias) }\end{array}$ & High risk & Unexplained high loss to follow-up. \\
\hline $\begin{array}{l}\text { All outcomes } \\
\text { pelective reporting (re- }\end{array}$ & Unclear risk & No protocol. \\
\hline \begin{tabular}{l} 
Other bias \\
\hline
\end{tabular} & Unclear risk & Funding not disclosed. \\
\hline
\end{tabular}

Carmona-Fonseca 2009 COL

\section{Study characteristics}

\begin{tabular}{ll}
\hline Methods & RCT \\
September 2003 to September 2006 \\
\hline Participants & 133 patients enrolled across 2 arms (total 188 counting arms not included in review) \\
Inclusion criteria \\
- Age $>2$ years. \\
- Pvivax parasitaemia of $>1000$ asexual forms $/ \mathrm{L}$. \\
- Willingness to participate. \\
- maquine base, and only individuals with normal G6PD levels were included in the study. \\
Exclusion criteria \\
- Pregnant women. \\
- Those with associated acute infectious diseases. \\
- A history of antimalarials intake during the previous 2 weeks. \\
- Presence of diarrhoea or vomiting (> 5 episodes in 24 hours). \\
- Symptoms or signs of severe malaria (according to WHO 2006). \\
- Hypersensitivity to antimalarials or severe undernutrition.
\end{tabular}


Carmona-Fonseca 2009 COL (Continued)

- Exclusion from the study also followed intake of any antimalarial different from those provided by the researchers.

- Failure to attend follow-up appointments.

- Treatment failure during the primary episode (first 28 days of follow-up).

- Consent withdrawal.

Diagnosis: microscopy.

No details CYP2D6 status or breastfeeding mothers.

Interventions

- Chloroquine (10 mg/kg day $1,7.5 \mathrm{mg} / \mathrm{kg}$ days 2 and 3 ) + primaquine $1.17 \mathrm{mg} / \mathrm{kg} /$ day for 3 days (total $210 \mathrm{mg}$ ).

- Chloroquine (10 mg/kg day $1,7.5 \mathrm{mg} / \mathrm{kg}$ days 2 and 3$)+$ primaquine $0.25 \mathrm{mg} / \mathrm{kg} /$ day for 14 days.

(Additional arms: $0.83 \mathrm{mg} / \mathrm{kg}$ day for 3 days (total dose $149.4 \mathrm{mg}$ ) and $0.58 \mathrm{mg} / \mathrm{kg}$ day for 3 days (total dose $104.4 \mathrm{mg}$ ) not included as total dose less than standard treatment)

Primaquine given simultaneously with chloroquine.

Supervised treatment.

\begin{tabular}{ll}
\hline Outcomes & Recurrence of $P$ vivax malaria (parasitaemia after day 28) \\
& Follow-up 120 days \\
\hline Notes & Location: Colombia \\
& Setting: patients that attended the local health clinics in Turbo and El Bagre \\
& $\begin{array}{l}\text { Funding: Colciencias (government agency), Dirección Seccional de Salud de Antioquia (DSSA), Universi- } \\
\text { dad de Antioquia }\end{array}$
\end{tabular}

\section{Risk of bias}

\begin{tabular}{lll}
\hline Bias & Authors' judgement & Support for judgement \\
\hline $\begin{array}{l}\text { Random sequence genera- } \\
\text { tion (selection bias) }\end{array}$ & Unclear risk & Details of randomization not given. \\
\hline $\begin{array}{l}\text { Allocation concealment } \\
\text { (selection bias) }\end{array}$ & Unclear risk & No details supplied. \\
\hline $\begin{array}{l}\text { Blinding of participants } \\
\text { and personnel (perfor- } \\
\text { mance bias) }\end{array}$ & High risk & Not blinded. \\
All outcomes & \\
\hline
\end{tabular}

$\begin{array}{ll}\text { Blinding of outcome as- } & \text { High risk } \quad \text { Not blinded and no mention on blinding in blood smear assessment. } \\ \text { sessment (detection bias) }\end{array}$

All outcomes

\begin{tabular}{lll}
\hline $\begin{array}{l}\text { Incomplete outcome data } \\
\text { (attrition bias) } \\
\text { All outcomes }\end{array}$ & Low risk & $\begin{array}{l}2 \text { lost per group, no explanations given, but less than 5\% of total across } \\
\text { groups. }\end{array}$ \\
\hline $\begin{array}{l}\text { Selective reporting (re- } \\
\text { porting bias) }\end{array}$ & Unclear risk & $\begin{array}{l}\text { Protocol not found. No safety data were provided (which might have been ex- } \\
\text { pected to have been provided). }\end{array}$ \\
\hline Other bias & Low risk & Government and academic funding. \\
\hline
\end{tabular}

Primaquine alternative dosing schedules for preventing malaria relapse in people with Plasmodium vivax (Review) 
Chu 2019 THA

\section{Study characteristics}

\begin{tabular}{ll}
\hline Methods & RCT \\
& February 2012 to July 2015 \\
\hline Participants & 680 participants enrolled. \\
& Inclusion criteria \\
- $\geq 6$ months & $\geq 7$ kg \\
- uncomplicated P vivax monoinfection \\
Exclusion criteria \\
- G6PD deficient by the fluorescent spot test \\
- Pregnant or breastfeeding an infant $\leq 6$ months \\
- Hematocrit $\leq 25 \%$ \\
- Blood transfusion within 3 months \\
Diagnosis: microscopy \\
No details CrP2D6
\end{tabular}

Interventions

- Chloroquine 3 days + primaquine 7 days $(1 \mathrm{mg} / \mathrm{kg} / \mathrm{day})$.

- Chloroquine 3 days + primaquine 14 days $(0.5 \mathrm{mg} / \mathrm{kg} /$ day).

- Dihydroartemisinin-piperaquine 3 days + primaquine 7 days ( $1 \mathrm{mg} / \mathrm{kg} /$ day).

- Dihydroartemisinin-piperaquine 3 days + primaquine 14 days $(0.5 \mathrm{mg} / \mathrm{kg} / \mathrm{day})$.

Supervised treatment.

Not specified whether primaquine given concurrently with chloroquine/dihydroartemisinin-piperaquine.

\section{Outcomes}

- Pvivax recurrence

- Adverse events

Follow-up: 3 months, 4 months, 6 months, 8 months, 1 year

Notes
Setting: Clinics along the Thailand-Myanmar border
Source of funding: The Wellcome Trust
Authors were contacted and provided 3-month and 6-month recurrence data for Analysis 4.3 and
Analysis 4.4

\section{Risk of bias}

\begin{tabular}{lll}
\hline Bias & Authors' judgement & Support for judgement \\
\hline $\begin{array}{l}\text { Random sequence genera- } \\
\text { tion (selection bias) }\end{array}$ & Low risk & Quote: "Randomization was computer generated in blocks of 20" \\
\hline
\end{tabular}


Chu 2019 THA (Continued)

\begin{tabular}{lll}
$\begin{array}{l}\text { Allocation concealment } \\
\text { (selection bias) }\end{array}$ & Unclear risk & Not reported \\
\hline $\begin{array}{l}\text { Blinding of participants } \\
\text { and personnel (perfor- }\end{array}$ & High risk & Quote: "open 2-way randomized controlled trial" \\
mance bias) & & \\
All outcomes &
\end{tabular}

\begin{tabular}{lll}
\hline $\begin{array}{l}\text { Blinding of outcome as- } \\
\text { sessment (detection bias) } \\
\text { All outcomes }\end{array}$ & High risk & Open-label and no mention of blood smear blinding \\
\hline $\begin{array}{l}\text { Incomplete outcome data } \\
\text { (attrition bias) }\end{array}$ & Unclear risk & $\begin{array}{l}\text { Overall, } 40 \% \text { left the study before the end of 1-year follow-up. } 4 \% \text { of enrolled } \\
\text { participants did not receive blood-stage treatment and were not included in } \\
\text { all outcomes }\end{array}$ \\
& $\begin{array}{l}\text { ter } 1 \text { year. No imputations were used to account for participants that left the } \\
\text { study early. However, dropouts were balanced between groups and reasons } \\
\text { for leaving the study were provided. }\end{array}$
\end{tabular}

\begin{tabular}{ll}
\hline $\begin{array}{l}\text { Selective reporting (re- } \\
\text { porting bias) }\end{array}$ & Low risk \\
& $\begin{array}{l}\text { NCT record (NCT01640574) reports little information on outcomes, however all } \\
\text { are reported in the study }\end{array}$
\end{tabular}

\begin{tabular}{ll}
\hline Other bias $\quad$ Low risk $\quad$ We did not detect any other sources of bias. \\
\hline
\end{tabular}

\section{Durand 2014 PER}

\section{Study characteristics}

\begin{tabular}{ll}
\hline Methods & RCT \\
& March 2006 to August 2008 \\
\hline Participants & 360 participants \\
Inclusion criteria & - Microscopy-confirmed diagnosis of monoinfection with $P$ vivax between 250 and 100,000 asexual par- \\
& asites/mL (determined by microscopic examination of thick and thin peripheral blood smears). \\
- Fever defined as axillary temperature $37.5^{\circ} \mathrm{C}$ or history of fever, or both. \\
- > 1 year old. \\
Exclusion criteria \\
- Pregnant and lactating women. \\
- Patients with chronic illnesses. \\
- Patients with symptoms of severe malaria. \\
- Patients with G6PD deficiency. \\
Diagnosis: light microscopy. \\
Parasite genotyping with PCR also performed - 5 microsatellite loci used to determine whether homol- \\
ogous relapse.
\end{tabular}

Interventions

- Chloroquine $(10 \mathrm{mg} / \mathrm{kg}$ day 1 and $2,5 \mathrm{mg} / \mathrm{kg}$ day 3$)+$ primaquine $0.5 \mathrm{mg} / \mathrm{kg} /$ day 7 days.

- Chloroquine (10 mg/kg day 1 and 2, $5 \mathrm{mg} / \mathrm{kg}$ day 3 ) + primaquine $0.25 \mathrm{mg} / \mathrm{kg} /$ day for 14 days. 
Durand 2014 PER (Continued)

(Additional arm of chloroquine + primaquine $0.5 \mathrm{mg} / \mathrm{kg} /$ day for 5 days excluded as total dose $150 \mathrm{mg}$, which was less than standard treatment.)

Supervised.

Primaquine administered concurrently with chloroquine.

\begin{tabular}{ll}
\hline Outcomes & Relapse between days 35 and 210 \\
- & Relapses (homologous only) \\
& Follow-up: 210 days \\
\hline Notes & Location: Peru \\
& Setting: Padre Cocha and the San Juan Health Centers and Santa Clara Health Center The periphery of \\
the city of Iquitos, which is located on the river bank of the Amazon River and is the largest city in the \\
Peruvian rainforest. \\
Funding: the US Department of Defense Global Emerging Infections Surveillance and Response Sys- \\
tem (DoD-GEIS), the National Institute of Health of Peru, and the Pan-American Health Organization/US \\
Agency for International Development (PAHO-USAID) Americas Malaria Initiative/Amazonic Network of \\
Antimalarial Drug Resistance, AMI/RAVREDA project.
\end{tabular}

\section{Risk of bias}

\begin{tabular}{lll}
\hline Bias & Authors' judgement & Support for judgement \\
\hline $\begin{array}{l}\text { Random sequence genera- } \\
\text { tion (selection bias) }\end{array}$ & Low risk & Computer-generated block randomization table. \\
\hline $\begin{array}{l}\text { Allocation concealment } \\
\text { (selection bias) }\end{array}$ & Low risk & $\begin{array}{l}\text { The treatment allocation for each participant was placed in a sealed envelope, } \\
\text { kept in an orderly manner, and opened only at the time of enrolment of a new } \\
\text { participant to prevent selection bias by study physicians. }\end{array}$
\end{tabular}

Blinding of participants $\quad$ High risk
and personnel (perfor-
mance bias)

$\begin{array}{lll}\text { Blinding of outcome as- } & \text { High risk } & \text { Open-label - no mention of blood smear blinding. } \\ \text { sessment (detection bias) }\end{array}$

All outcomes

Incomplete outcome data Low risk

$8 \%$ to $10 \%$ loss following randomization, but all accounted for.

(attrition bias)

All outcomes

\begin{tabular}{lll}
\hline $\begin{array}{l}\text { Selective reporting (re- } \\
\text { porting bias) }\end{array}$ & Low risk & $\begin{array}{l}\text { Study protocol registered. Unable to find outcomes in protocol, but expected } \\
\text { outcomes were reported on. }\end{array}$ \\
\hline Other bias & Low risk & We did not detect any other sources of bias. \\
\hline
\end{tabular}

Leslie 2008 PAK

\section{Study characteristics}

Methods RCT

Primaquine alternative dosing schedules for preventing malaria relapse in people with Plasmodium vivax (Review) 
Leslie 2008 PAK (Continued)

September 2004 to July 2006

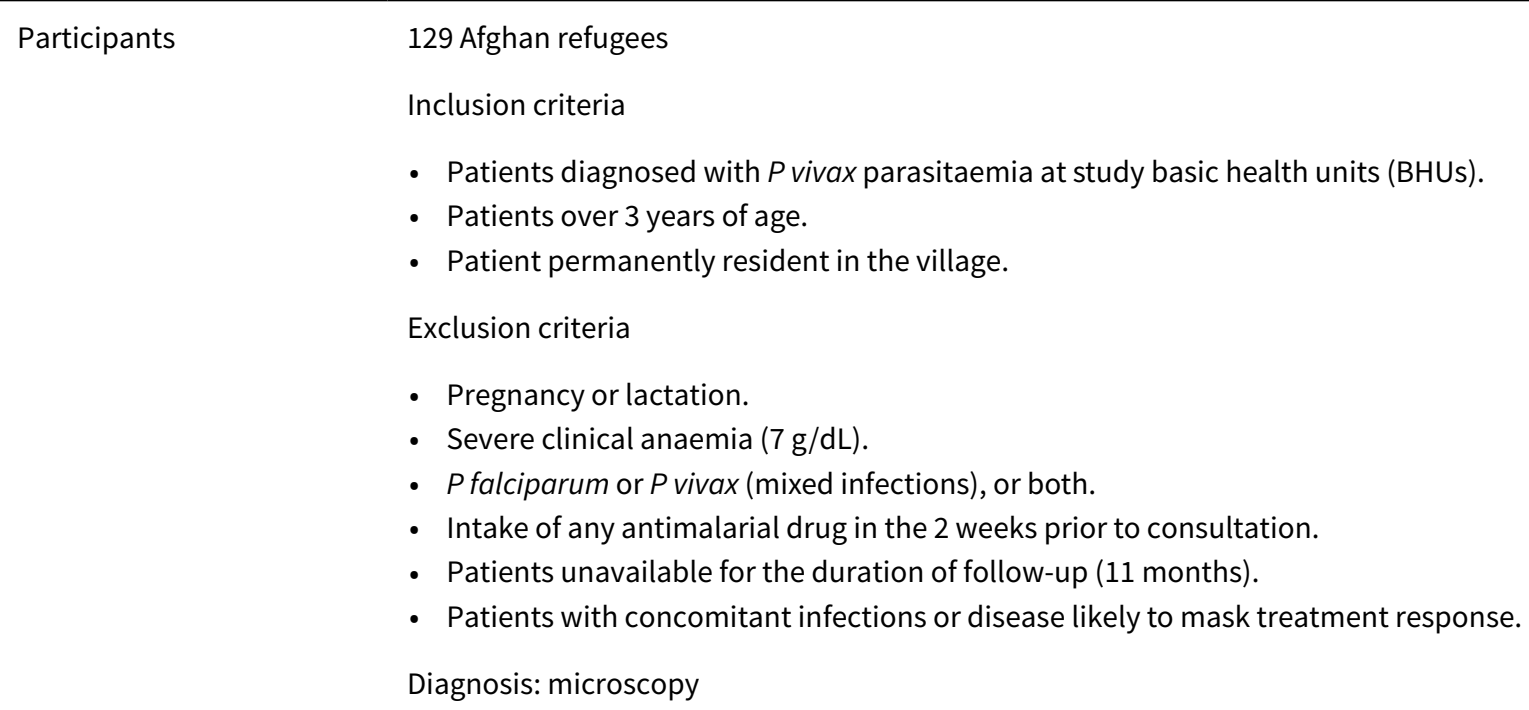

- Patients diagnosed with $P$ vivax parasitaemia at study basic health units (BHUs).

- Patients over 3 years of age.

- Patient permanently resident in the village.

Exclusion criteria

- Pregnancy or lactation.

- Severe clinical anaemia $(7 \mathrm{~g} / \mathrm{dL})$.

- Pfalciparum or P vivax (mixed infections), or both.

- Intake of any antimalarial drug in the 2 weeks prior to consultation.

- Patients unavailable for the duration of follow-up (11 months).

- Patients with concomitant infections or disease likely to mask treatment response.

Diagnosis: microscopy

- Chloroquine $(25 \mathrm{mg} / \mathrm{kg}$ in divided doses over 3 days $)+$ primaquine $0.75 \mathrm{mg} / \mathrm{kg}$ once weekly for 8 weeks.

- Chloroquine $(25 \mathrm{mg} / \mathrm{kg}$ in divided doses over 3 days) + primaquine $0.5 \mathrm{mg} / \mathrm{kg} /$ day for 14 days.

(Additional arm chloroquine + weekly placebo not included).

Supervised.

Not specified whether primaquine given concurrently with chloroquine.

- Pvivax malaria relapse
- The number of subsequent episodes and anaemia rates during and up to 2 weeks post-treatment as
well as any notable adverse events
Follow-up: 9 months (11 months participation: 8 weeks treatment + 9 months follow-up)

Notes
Location: Pakistan
Setting: Adizai, Baghicha, and Khagan villages, close to Peshawar, Northwest Frontier Province, Pak-
istan where Afghan refugees have been resident for more than 20 years
Funding: UNDP/World Bank/WHO Special Program for Research in Tropical Diseases; Gates Malaria
Partnership)

\section{Risk of bias}

\begin{tabular}{lll}
\hline Bias & Authors' judgement & Support for judgement \\
\hline $\begin{array}{l}\text { Random sequence genera- } \\
\text { tion (selection bias) }\end{array}$ & High risk & $\begin{array}{l}\text { Two randomization methods were used. In Baghicha and Khagan villages, par- } \\
\text { ticipants were randomized by household, whereas in Adizai, randomization } \\
\text { was at the individual level. Randomization lists for each village were generat- } \\
\text { ed using a random number list (MS Excel, Microsoft Corp, Seattle, USA) by staff } \\
\text { not involved in patient recruitment. Participants were randomized on enrol- } \\
\text { ment by study staff in the BHUs based on house number or sequential patient } \\
\text { numbers, depending on the study site. }\end{array}$
\end{tabular}

\begin{tabular}{|c|c|c|}
\hline $\begin{array}{l}\text { Allocation concealment } \\
\text { (selection bias) }\end{array}$ & High risk & $\begin{array}{l}\text { Participants were randomized on enrolment by study staff in the BHUs based } \\
\text { on house number or sequential patient numbers, depending on the study site. }\end{array}$ \\
\hline
\end{tabular}


Leslie 2008 PAK (Continued)

Blinding of participants High risk Open-label.
and personnel (perfor-
mance bias)
All outcomes

\begin{tabular}{|c|c|c|}
\hline $\begin{array}{l}\text { Blinding of outcome as- } \\
\text { sessment (detection bias) } \\
\text { All outcomes }\end{array}$ & Low risk & $\begin{array}{l}\text { Blood slides were double-read by } 2 \text { microscopists working independently, who } \\
\text { were blinded to the other's result. }\end{array}$ \\
\hline
\end{tabular}

All

Incomplete outcome data High risk (attrition bias)

Higher loss to follow-up in intervention group (6\% to $8 \%$ versus $1 \%$ to $1.8 \%$ ).

All outcomes

\begin{tabular}{lll}
\hline $\begin{array}{l}\text { Selective reporting (re- } \\
\text { porting bias) }\end{array}$ & Low risk & Trial protocol available, all planned outcomes reported on. \\
\hline Other bias & Low risk & We did not detect any other sources of bias. \\
\hline
\end{tabular}

Pareek 2015 IND

\section{Study characteristics}

\begin{tabular}{|c|c|}
\hline Methods & $\mathrm{RCT}$ \\
\hline Participants & $\begin{array}{l}\text { 358 participants } \\
\text { Inclusion criteria } \\
\text { - Patients of either sex. } \\
\text { - Aged between } 18 \text { and } 65 \text { years. } \\
\text { - Body weight }>40 \mathrm{~kg} \text {. } \\
\text { - Microscopically confirmed } P \text { vivax malaria with } \geq 1000 \text { asexual parasites/ } \mu \mathrm{L} \text { of blood. } \\
\text { - Axillary temperature } \geq 37.5^{\circ} \mathrm{C}\left(\geq 99.5^{\circ} \mathrm{F}\right) \text {. } \\
\text { - Presence of at least } 5 \text { of the following signs and symptoms of uncomplicated malaria: chills, nausea, } \\
\text { vomiting, headache, malaise, diarrhoea, anorexia, abdominal cramps, myalgia, and arthralgia. } \\
\text { Exclusion criteria } \\
\text { - Mixed malarial infections. } \\
\text { - Severe or complicated malaria (as defined by the WHO). } \\
\text { - G6PD deficiency. } \\
\text { - Any other significant concomitant illness. } \\
\text { - Patients with history of dark urine or significant haemoglobinuria related to previous primaquine } \\
\text { treatment or those with history of methaemoglobinaemia. } \\
\text { - Patients with protracted vomiting and oliguria. } \\
\text { - Those with underlying condition compromising bone marrow function or having a tendency to gran- } \\
\text { - ulocytopenia. } \\
\text { - Patients taking cardioactive drug or potentially haemolytic drugs or drugs that could interact with } \\
\text { study drugs. } \\
\text { - Patients having history of hypersensitivity to any of the study-related drugs. } \\
\text { - History/presence of substance abuse. } \\
\text { of birth control. }\end{array}$ \\
\hline
\end{tabular}


Pareek 2015 IND (Continued)

Diagnosis: microscopy.

Interventions - Chloroquine (3-day course, dose not specified) + primaquine $30 \mathrm{mg}$ sustained release 7 days.

- Chloroquine (3-day course, dose not specified) + primaquine $15 \mathrm{mg} 14$ days.

(Additional arm of chloroquine + primaquine $15 \mathrm{mg}$ sustained release for 14 days not included in review).

Primaquine given following completion of chloroquine course.

Not supervised.

\begin{tabular}{ll}
\hline Outcomes & Relapse \\
& - Compliance \\
- Safety & \\
PCR genotyping done to see if true relapse (no details on genotyping method). \\
Follow-up: 5 months (6 months participation) \\
\hline Lotes \\
Setting: multicentre, no details as to centres involved. \\
Funding: funded by drug manufacturer Ipca Laboratories Ltd. Anil Pareek and Nitin Chandurkar are the \\
employees of Ipca Laboratories Ltd who sponsored this trial.
\end{tabular}

\section{Risk of bias}

\begin{tabular}{lll}
\hline Bias & Authors' judgement & Support for judgement \\
\hline $\begin{array}{l}\text { Random sequence genera- } \\
\text { tion (selection bias) }\end{array}$ & Low risk & $\begin{array}{l}\text { Randomization codes were generated using computer-generated block ran- } \\
\text { domization method. }\end{array}$ \\
\hline $\begin{array}{l}\text { Allocation concealment } \\
\text { (selection bias) }\end{array}$ & Low risk & Patient-specific sealed boxes of medicine were provided to each study site. \\
& (Sequentially numbered, sealed, opaque envelopes (from protocol)). \\
\hline $\begin{array}{l}\text { Blinding of participants } \\
\text { and personnel (perfor- } \\
\text { mance bias) } \\
\begin{array}{l}\text { All outcomes } \\
\hline\end{array}\end{array}$ & Low risk & Double-blind, double-dummy. \\
\hline
\end{tabular}

\begin{tabular}{|c|c|c|}
\hline $\begin{array}{l}\text { Blinding of outcome as- } \\
\text { sessment (detection bias) }\end{array}$ & Unclear risk & $\begin{array}{l}\text { No details as to whether microscopy was blinded or whether there was double } \\
\text { reading of smears. }\end{array}$ \\
\hline
\end{tabular}

\begin{tabular}{|c|c|c|}
\hline $\begin{array}{l}\text { Incomplete outcome data } \\
\text { (attrition bias) }\end{array}$ & Low risk & $\begin{array}{l}\text { Loss to follow-up equal between groups. Relapses counted as discontinued } \\
\text { patients, but numbers provided so can be assessed. }\end{array}$ \\
\hline
\end{tabular}

All outcomes

Selective reporting (re- High risk
porting bias)
Compliance added as an outcome, but original outcomes also reported on. Not clear why they have concluded that compliance increased with SR, as par- ticipants had to take 3 sets of pills as did those who took dummy versions, so all participants took 3 sets of drugs.
No measurement of levels of PQ (pharmacokinetics), although states that PQ SR should have therapeutic concentration over 24 hours as part of the con- cept.


Pareek 2015 IND (Continued)

PCR results are not well-detailed.

Other bias Unclear risk The study was sponsored by Ipca Laboratories Ltd, who manufactures the
drugs, and the principal investigators are employees of the company.

\section{Rajgor 2014 IND}

\section{Study characteristics}

\begin{tabular}{ll}
\hline Methods & RCT \\
August 2001 to February 2004 \\
\hline Participants 1159 participants enrolled. \\
Inclusion criteria \\
- Adult patients, male and female (18 years of age or older). \\
- Peripheral blood smear diagnosis of $P$ vivax. \\
- Willing to undergo hospitalization for the entire duration of primaquine treatment. \\
- Willing to undergo investigations and come for regular follow-up. \\
- Normal G6PD. \\
- Haemoglobin $\geq 10$ g/dL. \\
Exclusion criteria \\
- Mixed infection with $P$ falciparum. \\
- Pregnancy and lactation. \\
- Evidence of significant hepatic, renal, or cardiac disease as diagnosed by history, clinical examination, \\
and laboratory tests whenever necessary. \\
- Any other condition that would interfere with patient's participation in the study or compliance with \\
the treatment. \\
Diagnosis: microscopy.
\end{tabular}

$\begin{array}{ll}\text { Interventions } & \text { Chloroquine }(10 \mathrm{mg} / \mathrm{kg} \text { day } 1 \text { and } 2,5 \mathrm{mg} / \mathrm{kg} \text { day } 3)+\text { primaquine } 30 \mathrm{mg} / \text { day } 7 \text { days. } \\ \text { - Chloroquine }(10 \mathrm{mg} / \mathrm{kg} \text { day } 1 \text { and } 2,5 \mathrm{mg} / \mathrm{kg} \text { day } 3)+\text { primaquine } 30 \mathrm{mg} / \text { day } 14 \text { days. } \\ \text { - Chloroquine }(10 \mathrm{mg} / \mathrm{kg} \text { day } 1 \text { and } 2,5 \mathrm{mg} / \mathrm{kg} \text { day } 3)+\text { primaquine } 15 \mathrm{mg} / \text { day } 14 \text { days. }\end{array}$

(Additional no-primaquine arm not included in analysis).

Supervised treatment.

Primquine treatment commenced after chloroquine treatment (day 4).

- Recurrence of vivax malaria
- Safety
Follow-up: 6 months
The secondary outcome also included comparison of number of participants classified as relapse and
re-infection by the 3 methods to determine the concordance between the methods used and the genet-
ic diversity observed based on PCR sequencing method. The cases of recurrence were classified as re-
lapse or re-infection based on the 3 methods, the month of recurrence, and the 2 genotyping methods:
PCR-RFLP and PCR sequencing.


Rajgor 2014 IND (Continued)

Setting: inpatient assessment in Mumbai.

Funding: Indian Council of Medical Research.

\section{Risk of bias}

Bias Authors' judgement Support for judgement

Random sequence genera- Low risk tion (selection bias)

A simple, computer-generated randomization scheme was used for the randomization of participants into the $3 \mathrm{PQ}$ regimen groups.

\begin{tabular}{|c|c|c|}
\hline $\begin{array}{l}\text { Allocation concealment } \\
\text { (selection bias) }\end{array}$ & High risk & $\begin{array}{l}\text { This was an open-label study, and no concealment of treatment allocation was } \\
\text { followed. }\end{array}$ \\
\hline
\end{tabular}

Blinding of participants

High risk

Open-label.

and personnel (perfor-

mance bias)

All outcomes

\begin{tabular}{|c|c|c|}
\hline $\begin{array}{l}\text { Blinding of outcome as- } \\
\text { sessment (detection bias) } \\
\text { All outcomes }\end{array}$ & Low risk & $\begin{array}{l}\text { Although the study was not blinded in terms of treatment administration, the } \\
\text { person seeing the slides and carrying out other outcome assessments was } \\
\text { blinded to the treatment group by coding of the samples. }\end{array}$ \\
\hline
\end{tabular}

\begin{tabular}{lll}
\hline $\begin{array}{l}\text { Incomplete outcome data } \\
\text { (attrition bias) }\end{array}$ & High risk & High percentage of participants not completing 6 months' follow-up across all \\
groups. Minimal explanation for discontinuation of participants.
\end{tabular}

All outcomes groups. Minimal explanation for discontinuation of participants.

\begin{tabular}{lll}
\hline $\begin{array}{l}\text { Selective reporting (re- } \\
\text { porting bias) }\end{array}$ & Unclear risk & $\begin{array}{l}\text { No registered protocol found - reported on expected outcomes of efficacy and } \\
\text { adverse events. Trial carried out 2001 to 2004 but not published until } 2014 .\end{array}$ \\
\hline Other bias & Low risk & We did not detect any other sources of bias. \\
\hline
\end{tabular}

Saravu 2018 IND

\section{Study characteristics}

\begin{tabular}{ll}
\hline Methods & RCT, open-label, pilot study \\
& March 2017 to August 2017 \\
\hline Participants & 50 participants enrolled. \\
& Patients presenting to Kasturba Hospital, Manipal and Dr TMA Pai Hospital, Udupi, India \\
Inclusion criteria & - P vivax malaria monoinfection. \\
- Age 18 years and over. \\
- Fever > $37.5^{\circ} \mathrm{C}$ tympanic or oral, or a history of fever within previous 3 days. \\
- Willing to give informed consent. \\
Exclusion criteria \\
- Pregnant or lactating, or both. \\
- Patients with G6PD deficiency. \\
- Mixed infection with P vivax and P falciparum. \\
Primaquine given after blood-stage treatment.
\end{tabular}

Primaquine alternative dosing schedules for preventing malaria relapse in people with Plasmodium vivax (Review) 
Saravu 2018 IND (Continued)

Diagnosis: microscopy, but PCR also performed to genotype recurrences.

No details CYP2D6.

Interventions Blood-stage treatment: either CQ or ACT (artesunate with doxycycline or artemether-lumefantrine as
per the treating clinician's judgement of severity).

- Primaquine $0.5 \mathrm{mg} / \mathrm{kg} /$ day for 14 days.

- Primaquine $0.25 \mathrm{mg} / \mathrm{kg} /$ day for 14 days.

Drug therapy not supervised.

\begin{tabular}{ll}
\hline Outcomes & 1. Recurrence. \\
(2. Primaquine level in the blood at 7 days) \\
Follow-up 6 months
\end{tabular}

Notes Location: Udupi district of Karnataka State, India

Setting: typical tropical climatic conditions. Malaria incidence throughout the year with peaks around June to July. Urban and rural settings in catchment area.

Source of funding: seed Grant Award from Manipal McGill Center for Infectious Diseases

\section{Risk of bias}

\begin{tabular}{|c|c|c|}
\hline Bias & Authors' judgement & Support for judgement \\
\hline $\begin{array}{l}\text { Random sequence genera- } \\
\text { tion (selection bias) }\end{array}$ & Low risk & $\begin{array}{l}\text { Block randomization - } 5 \text { blocks of } 10 \text {, randomization within each block done } \\
\text { by a lottery method. }\end{array}$ \\
\hline $\begin{array}{l}\text { Allocation concealment } \\
\text { (selection bias) }\end{array}$ & Unclear risk & No details. \\
\hline $\begin{array}{l}\text { Blinding of participants } \\
\text { and personnel (perfor- } \\
\text { mance bias) } \\
\text { All outcomes }\end{array}$ & High risk & Open-label. \\
\hline $\begin{array}{l}\text { Blinding of outcome as- } \\
\text { sessment (detection bias) } \\
\text { All outcomes }\end{array}$ & High risk & Open-label. \\
\hline $\begin{array}{l}\text { Incomplete outcome data } \\
\text { (attrition bias) } \\
\text { All outcomes }\end{array}$ & High risk & $\begin{array}{l}\text { High percentage of loss to follow-up by } 6 \text { months in both arms - results diffi- } \\
\text { cult to interpret. }\end{array}$ \\
\hline $\begin{array}{l}\text { Selective reporting (re- } \\
\text { porting bias) }\end{array}$ & Low risk & Outcomes reported as per protocol. \\
\hline Other bias & Low risk & $\begin{array}{l}\text { Supported by a seed Grant Award from Manipal McGill Center for Infectious } \\
\text { Diseases, MAHE, Manipal. }\end{array}$ \\
\hline
\end{tabular}

\section{Study characteristics}

Primaquine alternative dosing schedules for preventing malaria relapse in people with Plasmodium vivax (Review) 
Solari-Soto 2002 PER (Continued)

Methods RCT

October 1998 to January 1999

Participants
Inclusion criteria
- Confirmed diagnosis of $P$ vivax malaria (febrile and positive $P$ vivax blood smear).
Exclusion criteria
- Patients who had received antimalarial medication in the 4 weeks prior to diagnosis.
- Children under 5 years.
- Patients with severe concomitant diseases.
No details about inclusion/exclusion of G6PD-deficient/pregnant/breastfeeding patients.
Diagnosis: microscopy.

Interventions

- Chloroquine (10 mg/kg day 1 and 2, $5 \mathrm{mg} / \mathrm{kg}$ day 3$)+$ primaquine $0.25 \mathrm{mg} / \mathrm{kg} /$ day for 14 days.

- Chloroquine (10 mg/kg day 1 and 2, $5 \mathrm{mg} / \mathrm{kg}$ day 3 ) + primaquine $0.5 \mathrm{mg} / \mathrm{kg} /$ day for 7 days.

Directly observed therapy.

Primaquine given after chloroquine course.

\begin{tabular}{ll}
\hline Outcomes & Relapse \\
& Adverse events \\
& Follow-up: 60 days (total enrolment 60 days) \\
\hline Notes & Location: Peru. \\
& Setting: patients treated at San Martín de Pangoa Hospital, Junín \\
& Funding: US Naval Medical Research Institute Detachment.
\end{tabular}

\section{Risk of bias}

\begin{tabular}{lll}
\hline Bias & Authors' judgement & Support for judgement \\
\hline $\begin{array}{l}\text { Random sequence genera- } \\
\text { tion (selection bias) }\end{array}$ & Unclear risk & No details on randomization process. \\
\hline $\begin{array}{l}\text { Allocation concealment } \\
\text { (selection bias) }\end{array}$ & Unclear risk & No details on allocation process. \\
\hline $\begin{array}{l}\text { Blinding of participants } \\
\text { and personnel (perfor- } \\
\text { mance bias) }\end{array}$ & High risk & Open-label. \\
$\begin{array}{l}\text { All outcomes } \\
\text { Blinding of outcome as- } \\
\text { sessment (detection bias) } \\
\text { All outcomes }\end{array}$ & Unclear risk & Samples double-checked, but no details as to whether blinded. \\
\hline $\begin{array}{l}\text { Incomplete outcome data } \\
\text { (attrition bias) } \\
\text { All outcomes }\end{array}$ & Low risk & Missing data accounted for, similar in each group. \\
\hline
\end{tabular}

Primaquine alternative dosing schedules for preventing malaria relapse in people with Plasmodium vivax (Review) 
Solari-Soto 2002 PER (Continued)

Selective reporting (re- Unclear risk $\quad$ No details.
porting bias)

Other bias Low risk We did not detect any other sources of bias.

Taylor 2019 MULTI

\section{Study characteristics}

\begin{tabular}{ll}
\hline Methods & RCT, multicentre \\
July 2014 to November 2018 \\
\hline
\end{tabular}

Participants

2336 participants were randomised.

Inclusion criteria

- Participant (or parent/guardian of children below age of consent) is willing and able to give written informed consent to participate in the trial; verbal consent in the presence of a literate witness is required for illiterate patients. In addition, written assent (or verbal assent in the presence of a literate witness for illiterates) from children 12 to 17 years as per local practice.

- Monoinfection with $P$ vivax of any parasitaemia in countries that use chloroquine as blood schizonticidal therapy. Mixed infections with $P$ vivax and $P$ falciparum can be enrolled in countries that use an artemisinin combination therapy.

- Diagnosis based on rapid diagnostic tests.

- Over 6 months of age.

- Weight $5 \mathrm{~kg}$ or greater.

- Fever (axillary temperature $37.5^{\circ} \mathrm{C}$ ) or history of fever in the last 48 hours.

- Able (in the investigator's opinion) and willing to comply with the study requirements and follow-up.

Exclusion criteria

- Female participant who is pregnant, lactating, or planning pregnancy during the course of the study.

- Inability to tolerate oral treatment.

- Previous episode of haemolysis or severe haemoglobinuria following primaquine.

- Signs/symptoms indicative of severe/complicated malaria or warning signs requiring parenteral treatment - haemoglobin concentration less than $9 \mathrm{~g} / \mathrm{dL}$.

- Known hypersensitivity or allergy to the study drugs.

- Blood transfusion in last 90 days, since this can mask G6PD-deficient status.

- A febrile condition due to diseases other than malaria (for example, measles, acute lower respiratory tract infection, severe diarrhoea with dehydration).

- Presence of any condition which in the judgement of the investigator would place the participant at undue risk or interfere with the results of the study (for example, serious underlying cardiac, renal, or hepatic disease; severe malnutrition; HIV/AIDS; or severe febrile condition other than malaria); co-administration of other medication known to cause haemolysis or that could interfere with the assessment of antimalarial regimens.

- Currently taking medication known to interfere significantly with the pharmacokinetics of primaquine and the schizonticidal study drugs.

- Prior antimalarial medications in the previous 7 days.

Diagnosis: microscopy

Patients with G6PD deficiency were excluded from the randomised trial, but were enrolled into a parallel observational group and treated with chloroquine or dihydroartemisinin-piperaquine plus supervised primaquine $(0.75 \mathrm{mg} / \mathrm{kg})$ once a week for 8 weeks. 
Taylor 2019 MULTI (Continued)

No details CYP2D6 status.

- Standard blood schizonticidal therapy plus 7 days of supervised primaquine $(7 \mathrm{mg} / \mathrm{kg}$ total dose) ad-
ministered once per day $(1.0 \mathrm{mg} / \mathrm{kg}$ once daily) followed by 7 days of placebo.
- Standard blood schizonticidal therapy plus 14 days of supervised primaquine $(7 \mathrm{mg} / \mathrm{kg}$ total dose)
administered once per day $(0.5 \mathrm{mg} / \mathrm{kg})$.

(Additional arm Standard blood schizonticidal therapy plus 14 days placebo was not included in the review; no primaquine was administered to participants in this arm).

Supervised treatment.

Primaquine and blood schizonticidal therapy given concurrently.

Standard blood schizonticidal therapy was chloroquine in Ethiopia, Afghanistan, and Vietnam and dihydroartemisinin-piperaquine in Indonesia, according to local guidelines

$\begin{array}{ll}\text { - } & \text { Recurrent } P \text { vivax parasitaemia } \\ \text { - Adverse events } \\ \text { - Anaemia }\end{array}$

Follow-up: 28 days, 42 days, 3 months, 6 months, 1 year.

Notes Location: Afghanistan (Jalalabad, Laghman), Ethiopia (Arba Minch, Metahara), Indonesia (Hanura, Tanjung Leidong), and Vietnam (Dak O \& Bu Gia Map, Krong Pa).

Setting: Two health-care clinics in each country.

Funding: UK Department for International Development, UK Medical Research Council, UK National Institute for Health Research, and the Wellcome Trust through the Joint Global Health Trials Scheme and the Bill \& Melinda Gates Foundation.

Authors were contacted and provided 3-month and 6-month recurrence data presented in Appendix 3b.

\section{Risk of bias}

\begin{tabular}{lll}
\hline Bias & Authors' judgement & Support for judgement \\
\hline $\begin{array}{l}\text { Random sequence genera- } \\
\text { tion (selection bias) }\end{array}$ & Low risk & $\begin{array}{l}\text { Quote: "Randomisation was done using STATA version 14.1.(StataCorp, Col- } \\
\text { lege Station, TX, USA), which generated blocks of 20 for each dosing band”. }\end{array}$ \\
\hline $\begin{array}{l}\text { Allocation concealment } \\
\text { (selection bias) }\end{array}$ & Low risk & $\begin{array}{l}\text { Quote: "The independent statistician who generated the randomisation list } \\
\text { and selected code letters for primaquine or placebo was not otherwise in- } \\
\text { volved in the conduct of the trial and did not visit any of the study sites. Iden- } \\
\text { tical primaquine and placebo tablets were produced by the same manufactur- } \\
\text { er" }\end{array}$ \\
\hline
\end{tabular}

\begin{tabular}{|c|c|c|}
\hline $\begin{array}{l}\text { Blinding of participants } \\
\text { and personnel (perfor- } \\
\text { mance bias) } \\
\text { All outcomes }\end{array}$ & Low risk & $\begin{array}{l}\text { Quote: "Participants and all of the local study team were masked to treatment } \\
\text { assignments." }\end{array}$ \\
\hline $\begin{array}{l}\text { Blinding of outcome as- } \\
\text { sessment (detection bias) } \\
\text { All outcomes }\end{array}$ & Low risk & $\begin{array}{l}98.6 \% \text { accuracy in expert quality control of microscopy malaria films: Quote: } \\
\text { "Microscopists were trained in study laboratory procedures on-site and con- } \\
\text { tinuous quality control was implemented at all sites. Approximately } 10 \% \text { of } \\
\text { slides, including all the slides from day } 0 \text {, the day of recurrent parasitaemia, } \\
\text { and the } 6 \text {-month follow-up visits were assessed periodically over the course of } \\
\text { the trial by expert malaria microscopists" }\end{array}$ \\
\hline
\end{tabular}




\begin{tabular}{|c|c|c|}
\hline $\begin{array}{l}\text { Incomplete outcome data } \\
\text { (attrition bias) } \\
\text { All outcomes }\end{array}$ & Unclear risk & $\begin{array}{l}\text { Available case analysis, attrition after one year was } 32 \% \text { (297/935) in } 7 \text {-day pri- } \\
\text { maquine group and } 29 \%(270 / 937) \text { in 14-day primaquine group, reasons for } \\
\text { leaving the study early were reported. }\end{array}$ \\
\hline
\end{tabular}

\begin{tabular}{ll}
\hline $\begin{array}{l}\text { Selective reporting (re- } \\
\text { porting bias) }\end{array}$ & Low risk \\
& $\begin{array}{l}\text { Protocol and online trial registry were checked; all outcomes and sensitivity } \\
\text { analyses were reported. }\end{array}$
\end{tabular}

Other bias Low risk We did not detect any other sources of bias.

Abbreviations: ACT: artemisinin-based combination therapy; CQ: chloroquine; CYP2D6: cytochrome P450 2D6; G6PD: glucose-6-phosphate dehydrogenase; PCR: polymerase chain reaction; PCR-RFLP: polymerase chain reaction-restriction fragment length polymorphism; PQ: primaquine; RCT: randomized controlled trial; SE: standard error; SR: sustained release; WHO: World Health Organization.

Durand 2014 PER

\section{Study characteristics}

\begin{tabular}{|c|c|}
\hline Methods & $\begin{array}{l}\text { RCT } \\
\text { March } 2006 \text { to August } 2008\end{array}$ \\
\hline Participants & $\begin{array}{l}360 \text { participants } \\
\text { Inclusion criteria } \\
\text { - Microscopy-confirmed diagnosis of monoinfection with P vivax between } 250 \text { and } 100,000 \text { asexual par- } \\
\text { asites/mL (determined by microscopic examination of thick and thin peripheral blood smears). } \\
\text { - Fever defined as axillary temperature } 37.5^{\circ} \mathrm{C} \text { or history of fever, or both. } \\
\text { - > } 1 \text { year old. } \\
\text { Exclusion criteria } \\
\text { - Pregnant and lactating women. } \\
\text { - Patients with chronic illnesses. } \\
\text { - Patients with symptoms of severe malaria. } \\
\text { - Patients with G6PD deficiency. } \\
\text { Diagnosis: light microscopy. } \\
\text { Parasite genotyping with PCR also performed - } 5 \text { microsatellite loci used to determine whether homol- } \\
\text { ogous relapse. }\end{array}$ \\
\hline Interventions & $\begin{array}{l}\text { - Chloroquine (10 mg/kg day } 1 \text { and } 2,5 \mathrm{mg} / \mathrm{kg} \text { day } 3)+ \text { primaquine } 0.5 \mathrm{mg} / \mathrm{kg} / \text { day } 7 \text { days. } \\
\text { - Chloroquine }(10 \mathrm{mg} / \mathrm{kg} \text { day } 1 \text { and } 2,5 \mathrm{mg} / \mathrm{kg} \text { day } 3)+\text { primaquine } 0.25 \mathrm{mg} / \mathrm{kg} / \text { day for } 14 \text { days. } \\
\text { (Additional arm of chloroquine + primaquine } 0.5 \mathrm{mg} / \mathrm{kg} / \text { day for } 5 \text { days excluded as total dose } 150 \mathrm{mg} \text {, } \\
\text { which was less than standard treatment.) } \\
\text { Supervised. } \\
\text { Primaquine administered concurrently with chloroquine. }\end{array}$ \\
\hline Outcomes & $\begin{array}{l}\text { - Relapse between days } 35 \text { and } 210 \\
\text { - Relapses (homologous only) } \\
\text { Follow-up: } 210 \text { days }\end{array}$ \\
\hline
\end{tabular}


Durand 2014 PER (Continued)

Lotes
Setting: Padre Cocha and the San Juan Health Centers and Santa Clara Health Center The periphery of
the city of Iquitos, which is located on the river bank of the Amazon River and is the largest city in the
Peruvian rainforest.
Funding: the US Department of Defense Global Emerging Infections Surveillance and Response Sys-
tem (DoD-GEIS), the National Institute of Health of Peru, and the Pan-American Health Organization/US
Agency for International Development (PAHO-USAID) Americas Malaria Initiative/Amazonic Network of
Antimalarial Drug Resistance, AMI/RAVREDA project.

\section{Risk of bias}

\begin{tabular}{lll}
\hline Bias & Authors' judgement & Support for judgement \\
\hline $\begin{array}{l}\text { Random sequence genera- } \\
\text { tion (selection bias) }\end{array}$ & Low risk & Computer-generated block randomization table. \\
\hline $\begin{array}{l}\text { Allocation concealment } \\
\text { selection bias) }\end{array}$ & Low risk & $\begin{array}{l}\text { The treatment allocation for each participant was placed in a sealed envelope, } \\
\text { kept in an orderly manner, and opened only at the time of enrolment of a new } \\
\text { participant to prevent selection bias by study physicians. }\end{array}$ \\
\hline $\begin{array}{l}\text { Blinding of participants } \\
\text { and personnel (perfor- } \\
\begin{array}{l}\text { mance bias) } \\
\text { All outcomes }\end{array}\end{array}$ High risk & Open-label. \\
\hline
\end{tabular}

\section{Leslie 2008 PAK}

\section{Study characteristics}

\begin{tabular}{ll}
\hline Methods & RCT \\
& September 2004 to July 2006 \\
\hline Participants & 129 Afghan refugees \\
Inclusion criteria & - Patients diagnosed with P vivax parasitaemia at study basic health units (BHUs). \\
- Patients over 3 years of age. \\
- Patient permanently resident in the village. \\
Exclusion criteria
\end{tabular}

Primaquine alternative dosing schedules for preventing malaria relapse in people with Plasmodium vivax (Review) 
Leslie 2008 PAK (Continued)

- Pregnancy or lactation.

- Severe clinical anaemia $(7 \mathrm{~g} / \mathrm{dL})$.

- Pfalciparum or $P$ vivax (mixed infections), or both.

- Intake of any antimalarial drug in the 2 weeks prior to consultation.

- Patients unavailable for the duration of follow-up (11 months).

- Patients with concomitant infections or disease likely to mask treatment response.

Diagnosis: microscopy

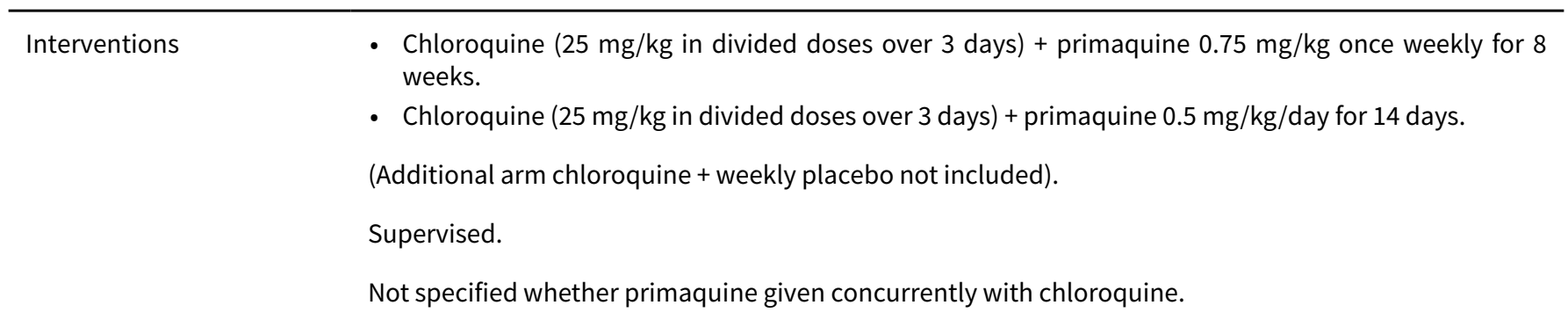

Outcomes

- P vivax malaria relapse

- The number of subsequent episodes and anaemia rates during and up to 2 weeks post-treatment as well as any notable adverse events

Follow-up: 9 months (11 months participation: 8 weeks treatment + 9 months follow-up)

Notes
Location: Pakistan
Setting: Adizai, Baghicha, and Khagan villages, close to Peshawar, Northwest Frontier Province, Pak-
Funding: UNDP/World Bank/WHO Special Program for Research in Tropical Diseases; Gates Malaria
Fartnership)

\section{Risk of bias}

\begin{tabular}{lll}
\hline Bias & Authors' judgement & Support for judgement \\
\hline $\begin{array}{l}\text { Random sequence genera- } \\
\text { tion (selection bias) }\end{array}$ & High risk & $\begin{array}{l}\text { Two randomization methods were used. In Baghicha and Khagan villages, par- } \\
\text { ticipants were randomized by household, whereas in Adizai, randomization } \\
\text { was at the individual level. Randomization lists for each village were generat- } \\
\text { ed using a random number list (MS Excel, Microsoft Corp, Seattle, USA) by staff } \\
\text { not involved in patient recruitment. Participants were randomized on enrol- } \\
\text { ment by study staff in the BHUs based on house number or sequential patient } \\
\text { numbers, depending on the study site. }\end{array}$
\end{tabular}

\begin{tabular}{lll}
\hline $\begin{array}{l}\text { Allocation concealment } \\
\text { (selection bias) }\end{array}$ & High risk & $\begin{array}{l}\text { Participants were randomized on enrolment by study staff in the BHUs based } \\
\text { on house number or sequential patient numbers, depending on the study site. }\end{array}$ \\
\hline $\begin{array}{l}\text { Blinding of participants } \\
\text { and personnel (perfor- } \\
\text { mance bias) }\end{array}$ & High risk & Open-label. \\
All outcomes & \\
\hline
\end{tabular}

\begin{tabular}{|c|c|c|}
\hline $\begin{array}{l}\text { Blinding of outcome as- } \\
\text { sessment (detection bias) }\end{array}$ & Low risk & $\begin{array}{l}\text { Blood slides were double-read by } 2 \text { microscopists working independently, who } \\
\text { were blinded to the other's result. }\end{array}$ \\
\hline
\end{tabular}

All outcomes

$\begin{aligned} & \text { Incomplete outcome data } \\ & \text { (attrition bias) }\end{aligned}$ High risk Higher loss to follow-up in intervention group (6\% to $8 \%$ versus $1 \%$ to $1.8 \%$ ).


Leslie 2008 PAK (Continued)

All outcomes

Selective reporting (re- $\quad$ Low risk
porting bias)

Other bias Low risk We did not detect any other sources of bias.

\section{Pareek 2015 IND}

\section{Study characteristics}

\begin{tabular}{|c|c|}
\hline Methods & RCT \\
\hline Participants & $\begin{array}{l}358 \text { participants } \\
\text { Inclusion criteria } \\
\text { - Patients of either sex. } \\
\text { - Aged between } 18 \text { and } 65 \text { years. } \\
\text { - Body weight }>40 \mathrm{~kg} \text {. } \\
\text { - Microscopically confirmed } P \text { vivax malaria with } \geq 1000 \text { asexual parasites } / \mu \mathrm{L} \text { of blood. } \\
\text { - Axillary temperature } \geq 37.5^{\circ} \mathrm{C}\left(\geq 99.5^{\circ} \mathrm{F}\right) \text {. } \\
\text { - Presence of at least } 5 \text { of the following signs and symptoms of uncomplicated malaria: chills, nausea, } \\
\text { vomiting, headache, malaise, diarrhoea, anorexia, abdominal cramps, myalgia, and arthralgia. } \\
\text { Exclusion criteria } \\
\text { - Mixed malarial infections. } \\
\text { - Severe or complicated malaria (as defined by the WHO). } \\
\text { - G6PD deficiency. } \\
\text { - Any other significant concomitant illness. } \\
\text { - Patients with history of dark urine or significant haemoglobinuria related to previous primaquine } \\
\text { treatment or those with history of methaemoglobinaemia. } \\
\text { - Patients with protracted vomiting and oliguria. } \\
\text { - Those with underlying condition compromising bone marrow function or having a tendency to gran- } \\
\text { - } \text { ulocytopenia. } \\
\text { - Patients taking cardioactive drug or potentially haemolytic drugs or drugs that could interact with } \\
\text { - Patudy drugs. } \\
\text { - History } / \text { presence of substance abuse. } \\
\text { of birth control. }\end{array}$ \\
\hline & Diagnosis: microscopy. \\
\hline Interventions & $\begin{array}{l}\text { - Chloroquine (3-day course, dose not specified) + primaquine } 30 \mathrm{mg} \text { sustained release } 7 \text { days. } \\
\text { Chloroquine (3-day course, dose not specified) + primaquine } 15 \mathrm{mg} 14 \text { days. } \\
\text { (Additional arm of chloroquine + primaquine } 15 \mathrm{mg} \text { sustained release for } 14 \text { days not included in re- } \\
\text { view). } \\
\text { Primaquine given following completion of chloroquine course. } \\
\text { Not supervised. }\end{array}$ \\
\hline
\end{tabular}


Pareek 2015 IND (Continued)
Outcomes
- Relapse
- Compliance
- Safety
PCR genotyping done to see if true relapse (no details on genotyping method).
Follow-up: 5 months ( 6 months participation)

Location: India.
Setting: multicentre, no details as to centres involved.
Funding: funded by drug manufacturer Ipca Laboratories Ltd. Anil Pareek and Nitin Chandurkar are the
employees of Ipca Laboratories Ltd who sponsored this trial.

\section{Risk of bias}

\begin{tabular}{lll}
\hline Bias & Authors' judgement & Support for judgement \\
\hline $\begin{array}{l}\text { Random sequence genera- } \\
\text { tion (selection bias) }\end{array}$ & Low risk & $\begin{array}{l}\text { Randomization codes were generated using computer-generated block ran- } \\
\text { domization method. }\end{array}$ \\
\hline $\begin{array}{l}\text { Allocation concealment } \\
\text { (selection bias) }\end{array}$ & Low risk & Patient-specific sealed boxes of medicine were provided to each study site. \\
& (Sequentially numbered, sealed, opaque envelopes (from protocol)). \\
$\begin{array}{l}\text { Blinding of participants } \\
\begin{array}{l}\text { and personnel (perfor- } \\
\text { mance bias) } \\
\text { All outcomes }\end{array}\end{array}$ & Low risk & Double-blind, double-dummy. \\
\hline
\end{tabular}

Blinding of outcome as- Unclear risk sessment (detection bias) All outcomes
No details as to whether microscopy was blinded or whether there was double reading of smears.

$\begin{array}{ll}\begin{array}{l}\text { Incomplete outcome data } \\ \text { (attrition bias) }\end{array} & \text { Low risk }\end{array}$

All outcomes

Selective reporting (re- High risk porting bias)

\begin{abstract}
Compliance added as an outcome, but original outcomes also reported on. Not clear why they have concluded that compliance increased with SR, as participants had to take 3 sets of pills as did those who took dummy versions, so all participants took 3 sets of drugs.

No measurement of levels of PQ (pharmacokinetics), although states that PQ SR should have therapeutic concentration over 24 hours as part of the concept.

PCR results are not well-detailed.
\end{abstract}

\begin{tabular}{|c|c|c|}
\hline Other bias & Unclear risk & $\begin{array}{l}\text { The study was sponsored by Ipca Laboratories Ltd, who manufactures the } \\
\text { drugs, and the principal investigators are employees of the company. }\end{array}$ \\
\hline
\end{tabular}

\section{Study characteristics}


Rajgor 2014 IND (Continued)

Methods RCT

August 2001 to February 2004

Participants

1159 participants enrolled.

Inclusion criteria

- Adult patients, male and female (18 years of age or older).

- Peripheral blood smear diagnosis of $P$ vivax.

- Willing to undergo hospitalization for the entire duration of primaquine treatment.

- Willing to provide informed consent.

- Willing to undergo investigations and come for regular follow-up.

- Normal G6PD.

- Haemoglobin $\geq 10 \mathrm{~g} / \mathrm{dL}$.

Exclusion criteria

- Mixed infection with P falciparum.

- Pregnancy and lactation.

- Evidence of significant hepatic, renal, or cardiac disease as diagnosed by history, clinical examination, and laboratory tests whenever necessary.

- Any other condition that would interfere with patient's participation in the study or compliance with the treatment.

Diagnosis: microscopy.

- Chloroquine (10 mg/kg day 1 and 2, $5 \mathrm{mg} / \mathrm{kg}$ day 3$)+$ primaquine $30 \mathrm{mg} /$ day 7 days.

- Chloroquine (10 mg/kg day 1 and $2,5 \mathrm{mg} / \mathrm{kg}$ day 3$)+$ primaquine $30 \mathrm{mg} /$ day 14 days.

- Chloroquine (10 mg/kg day 1 and $2,5 \mathrm{mg} / \mathrm{kg}$ day 3$)+$ primaquine $15 \mathrm{mg} /$ day 14 days.

(Additional no-primaquine arm not included in analysis).

Supervised treatment.

Primquine treatment commenced after chloroquine treatment (day 4).

- Recurrence of vivax malaria
- Safety
Follow-up: 6 months
The secondary outcome also included comparison of number of participants classified as relapse and
re-infection by the 3 methods to determine the concordance between the methods used and the genet-
ic diversity observed based on PCR sequencing method. The cases of recurrence were classified as re-
lapse or re-infection based on the 3 methods, the month of recurrence, and the 2 genotyping methods:
PCR-RFLP and PCR sequencing.

Notes $\quad$ Location: Mumbai, India.

Setting: inpatient assessment in Mumbai.

Funding: Indian Council of Medical Research.

\section{Risk of bias}

Bias Authors' judgement Support for judgement


Rajgor 2014 IND (Continued)

$\begin{array}{ll}\begin{array}{l}\text { Random sequence genera- } \\ \text { tion (selection bias) }\end{array} & \text { Low risk }\end{array} \quad \begin{aligned} & \text { A simple, computer-generated randomization scheme was used for the ran- } \\ & \text { domization of participants into the 3 PQ regimen groups. }\end{aligned}$

Allocation concealment High risk
(selection bias)

This was an open-label study, and no concealment of treatment allocation was (selection bias) followed.

Blinding of participants High risk $\quad$ Open-label.
and personnel (perfor-
mance bias)
All outcomes

\begin{tabular}{|c|c|c|}
\hline $\begin{array}{l}\text { Blinding of outcome as- } \\
\text { sessment (detection bias) } \\
\text { All outcomes }\end{array}$ & Low risk & $\begin{array}{l}\text { Although the study was not blinded in terms of treatment administration, the } \\
\text { person seeing the slides and carrying out other outcome assessments was } \\
\text { blinded to the treatment group by coding of the samples. }\end{array}$ \\
\hline
\end{tabular}

\begin{tabular}{|c|c|c|}
\hline $\begin{array}{l}\text { Incomplete outcome data } \\
\text { (attrition bias) }\end{array}$ & High risk & $\begin{array}{l}\text { High percentage of participants not completing } 6 \text { months' follow-up across all } \\
\text { groups. Minimal explanation for discontinuation of participants. }\end{array}$ \\
\hline
\end{tabular}

\begin{tabular}{lll}
\hline $\begin{array}{l}\text { Selective reporting (re- } \\
\text { porting bias) }\end{array}$ & Unclear risk & $\begin{array}{l}\text { No registered protocol found - reported on expected outcomes of efficacy and } \\
\text { adverse events. Trial carried out 2001 to 2004 but not published until 2014. }\end{array}$ \\
\hline Other bias & Low risk & We did not detect any other sources of bias. \\
\hline
\end{tabular}

\title{
Saravu 2018 IND
}

\section{Study characteristics}

\begin{tabular}{ll}
\hline Methods & RCT, open-label, pilot study \\
March 2017 to August 2017 \\
\hline
\end{tabular}

Participants

\author{
50 participants enrolled.
}

Patients presenting to Kasturba Hospital, Manipal and Dr TMA Pai Hospital, Udupi, India

Inclusion criteria

- Pvivax malaria monoinfection.

- Age 18 years and over.

- Fever $>37.5^{\circ} \mathrm{C}$ tympanic or oral, or a history of fever within previous 3 days.

- Willing to give informed consent.

Exclusion criteria

- Pregnant or lactating, or both.

- Patients with G6PD deficiency.

- Mixed infection with $P$ vivax and $P$ falciparum.

Primaquine given after blood-stage treatment.

Diagnosis: microscopy, but PCR also performed to genotype recurrences.

No details CYP2D6.

Interventions

Blood-stage treatment: either CQ or ACT (artesunate with doxycycline or artemether-lumefantrine as per the treating clinician's judgement of severity). 
Saravu 2018 IND (Continued)

- Primaquine $0.5 \mathrm{mg} / \mathrm{kg} /$ day for 14 days.

- Primaquine $0.25 \mathrm{mg} / \mathrm{kg} /$ day for 14 days.

Drug therapy not supervised.

\begin{tabular}{ll}
\hline Outcomes & Recurrence. \\
(2. Primaquine level in the blood at 7 days) \\
Follow-up 6 months
\end{tabular}

Notes Location: Udupi district of Karnataka State, India

Setting: typical tropical climatic conditions. Malaria incidence throughout the year with peaks around June to July. Urban and rural settings in catchment area.

Source of funding: seed Grant Award from Manipal McGill Center for Infectious Diseases

\section{Risk of bias}

\begin{tabular}{|c|c|c|}
\hline Bias & Authors' judgement & Support for judgement \\
\hline $\begin{array}{l}\text { Random sequence genera- } \\
\text { tion (selection bias) }\end{array}$ & Low risk & $\begin{array}{l}\text { Block randomization - } 5 \text { blocks of } 10 \text {, randomization within each block done } \\
\text { by a lottery method. }\end{array}$ \\
\hline $\begin{array}{l}\text { Allocation concealment } \\
\text { (selection bias) }\end{array}$ & Unclear risk & No details. \\
\hline $\begin{array}{l}\text { Blinding of participants } \\
\text { and personnel (perfor- } \\
\text { mance bias) } \\
\text { All outcomes }\end{array}$ & High risk & Open-label. \\
\hline $\begin{array}{l}\text { Blinding of outcome as- } \\
\text { sessment (detection bias) } \\
\text { All outcomes }\end{array}$ & High risk & Open-label. \\
\hline $\begin{array}{l}\text { Incomplete outcome data } \\
\text { (attrition bias) } \\
\text { All outcomes }\end{array}$ & High risk & $\begin{array}{l}\text { High percentage of loss to follow-up by } 6 \text { months in both arms - results diffi- } \\
\text { cult to interpret. }\end{array}$ \\
\hline $\begin{array}{l}\text { Selective reporting (re- } \\
\text { porting bias) }\end{array}$ & Low risk & Outcomes reported as per protocol. \\
\hline Other bias & Low risk & $\begin{array}{l}\text { Supported by a seed Grant Award from Manipal McGill Center for Infectious } \\
\text { Diseases, MAHE, Manipal. }\end{array}$ \\
\hline
\end{tabular}

Solari-Soto 2002 PER

\section{Study characteristics}

\begin{tabular}{ll}
\hline Methods & RCT \\
& October 1998 to January 1999 \\
\hline Participants & 60 participants enrolled. \\
& Inclusion criteria
\end{tabular}

Primaquine alternative dosing schedules for preventing malaria relapse in people with Plasmodium vivax (Review) 
- Confirmed diagnosis of $P$ vivax malaria (febrile and positive $P$ vivax blood smear).

Exclusion criteria

- Patients who had received antimalarial medication in the 4 weeks prior to diagnosis.

- Children under 5 years.

- Patients with severe concomitant diseases.

No details about inclusion/exclusion of G6PD-deficient/pregnant/breastfeeding patients.

Diagnosis: microscopy.

Interventions

- Chloroquine (10 mg/kg day 1 and $2,5 \mathrm{mg} / \mathrm{kg}$ day 3$)+$ primaquine $0.25 \mathrm{mg} / \mathrm{kg} /$ day for 14 days.

- Chloroquine (10 mg/kg day 1 and 2, $5 \mathrm{mg} / \mathrm{kg}$ day 3 ) + primaquine $0.5 \mathrm{mg} / \mathrm{kg} /$ day for 7 days.

Directly observed therapy.

Primaquine given after chloroquine course.

\begin{tabular}{ll}
\hline Outcomes & Relapse \\
& Follow-up: 60 days (total enrolment 60 days) \\
\hline Notes & Location: Peru. \\
& Setting: patients treated at San Martín de Pangoa Hospital, Junín \\
& Funding: US Naval Medical Research Institute Detachment. \\
\hline
\end{tabular}

\section{Risk of bias}

\begin{tabular}{lll}
\hline Bias & Authors' judgement & Support for judgement \\
\hline $\begin{array}{l}\text { Random sequence genera- } \\
\text { tion (selection bias) }\end{array}$ & Unclear risk & No details on randomization process. \\
\hline $\begin{array}{l}\text { Allocation concealment } \\
\text { (selection bias) }\end{array}$ & Unclear risk & No details on allocation process. \\
\hline $\begin{array}{l}\text { Blinding of participants } \\
\text { and personnel (perfor- } \\
\text { mance bias) }\end{array}$ & High risk & Open-label. \\
$\begin{array}{l}\text { All outcomes } \\
\text { Blinding of outcome as- } \\
\text { sessment (detection bias) } \\
\text { All outcomes }\end{array}$ & Unclear risk & Samples double-checked, but no details as to whether blinded. \\
\hline $\begin{array}{l}\text { Incomplete outcome data } \\
\text { (attrition bias) }\end{array}$ & Low risk & Missing data accounted for, similar in each group. \\
$\begin{array}{l}\text { All outcomes } \\
\begin{array}{l}\text { Selective reporting (re- } \\
\text { porting bias) }\end{array}\end{array}$ & Unclear risk & No details. \\
\hline \begin{tabular}{l} 
Other bias \\
\hline
\end{tabular} & Low risk & We did not detect any other sources of bias. \\
\hline
\end{tabular}


Taylor 2019 MULTI

\section{Study characteristics}

\begin{tabular}{ll}
\hline Methods & RCT, multicentre \\
July 2014 to November 2018 \\
\hline
\end{tabular}

Participants

2336 participants were randomised.

Inclusion criteria

- Participant (or parent/guardian of children below age of consent) is willing and able to give written informed consent to participate in the trial; verbal consent in the presence of a literate witness is required for illiterate patients. In addition, written assent (or verbal assent in the presence of a literate witness for illiterates) from children 12 to 17 years as per local practice.

- Monoinfection with $P$ vivax of any parasitaemia in countries that use chloroquine as blood schizonticidal therapy. Mixed infections with $P$ vivax and $P$ falciparum can be enrolled in countries that use an artemisinin combination therapy.

- Diagnosis based on rapid diagnostic tests.

- Over 6 months of age.

- Weight $5 \mathrm{~kg}$ or greater.

- Fever (axillary temperature $37.5^{\circ} \mathrm{C}$ ) or history of fever in the last 48 hours.

- Able (in the investigator's opinion) and willing to comply with the study requirements and follow-up.

Exclusion criteria

- Female participant who is pregnant, lactating, or planning pregnancy during the course of the study.

- Inability to tolerate oral treatment.

- Previous episode of haemolysis or severe haemoglobinuria following primaquine.

- Signs/symptoms indicative of severe/complicated malaria or warning signs requiring parenteral treatment - haemoglobin concentration less than $9 \mathrm{~g} / \mathrm{dL}$.

- Known hypersensitivity or allergy to the study drugs.

- Blood transfusion in last 90 days, since this can mask G6PD-deficient status.

- A febrile condition due to diseases other than malaria (for example, measles, acute lower respiratory tract infection, severe diarrhoea with dehydration).

- Presence of any condition which in the judgement of the investigator would place the participant at undue risk or interfere with the results of the study (for example, serious underlying cardiac, renal, or hepatic disease; severe malnutrition; HIV/AIDS; or severe febrile condition other than malaria); co-administration of other medication known to cause haemolysis or that could interfere with the assessment of antimalarial regimens.

- Currently taking medication known to interfere significantly with the pharmacokinetics of primaquine and the schizonticidal study drugs.

- Prior antimalarial medications in the previous 7 days.

Diagnosis: microscopy

Patients with G6PD deficiency were excluded from the randomised trial, but were enrolled into a parallel observational group and treated with chloroquine or dihydroartemisinin-piperaquine plus supervised primaquine $(0.75 \mathrm{mg} / \mathrm{kg})$ once a week for 8 weeks.

No details CYP2D6 status.

Interventions

- Standard blood schizonticidal therapy plus 7 days of supervised primaquine ( $7 \mathrm{mg} / \mathrm{kg}$ total dose) administered once per day ( $1.0 \mathrm{mg} / \mathrm{kg}$ once daily) followed by 7 days of placebo.

- Standard blood schizonticidal therapy plus 14 days of supervised primaquine ( $7 \mathrm{mg} / \mathrm{kg}$ total dose) administered once per day $(0.5 \mathrm{mg} / \mathrm{kg})$.

(Additional arm Standard blood schizonticidal therapy plus 14 days placebo was not included in the review; no primaquine was administered to participants in this arm). 
Taylor 2019 MULTI (Continued)

Supervised treatment.

Primaquine and blood schizonticidal therapy given concurrently.

Standard blood schizonticidal therapy was chloroquine in Ethiopia, Afghanistan, and Vietnam and dihydroartemisinin-piperaquine in Indonesia, according to local guidelines

\begin{tabular}{ll}
\hline Outcomes & Recurrent $P$ vivax parasitaemia \\
& - Adverse events \\
& Anaemia \\
& Follow-up: 28 days, 42 days, 3 months, 6 months, 1 year.
\end{tabular}

Notes

Location: Afghanistan (Jalalabad, Laghman), Ethiopia (Arba Minch, Metahara), Indonesia (Hanura, Tanjung Leidong), and Vietnam (Dak O \& Bu Gia Map, Krong Pa).

Setting: Two health-care clinics in each country.

Funding: UK Department for International Development, UK Medical Research Council, UK National Institute for Health Research, and the Wellcome Trust through the Joint Global Health Trials Scheme and the Bill \& Melinda Gates Foundation.

Authors were contacted and provided 3-month and 6-month recurrence data presented in Appendix 3b.

\section{Risk of bias}

\begin{tabular}{|c|c|c|}
\hline Bias & Authors' judgement & Support for judgement \\
\hline $\begin{array}{l}\text { Random sequence genera- } \\
\text { tion (selection bias) }\end{array}$ & Low risk & $\begin{array}{l}\text { Quote: "Randomisation was done using STATA version 14.1.(StataCorp, Col- } \\
\text { lege Station, TX, USA), which generated blocks of } 20 \text { for each dosing band". }\end{array}$ \\
\hline $\begin{array}{l}\text { Allocation concealment } \\
\text { (selection bias) }\end{array}$ & Low risk & $\begin{array}{l}\text { Quote: "The independent statistician who generated the randomisation list } \\
\text { and selected code letters for primaquine or placebo was not otherwise in- } \\
\text { volved in the conduct of the trial and did not visit any of the study sites. Iden- } \\
\text { tical primaquine and placebo tablets were produced by the same manufactur- } \\
\text { er" }\end{array}$ \\
\hline $\begin{array}{l}\text { Blinding of participants } \\
\text { and personnel (perfor- } \\
\text { mance bias) } \\
\text { All outcomes }\end{array}$ & Low risk & $\begin{array}{l}\text { Quote: "Participants and all of the local study team were masked to treatment } \\
\text { assignments." }\end{array}$ \\
\hline \multirow[t]{2}{*}{$\begin{array}{l}\text { Blinding of outcome as- } \\
\text { sessment (detection bias) } \\
\text { All outcomes }\end{array}$} & Low risk & $\begin{array}{l}98.6 \% \text { accuracy in expert quality control of microscopy malaria films: Quote: } \\
\text { "Microscopists were trained in study laboratory procedures on-site and con- } \\
\text { tinuous quality control was implemented at all sites. Approximately } 10 \% \text { of } \\
\text { slides, including all the slides from day } 0 \text {, the day of recurrent parasitaemia, } \\
\text { and the } 6 \text {-month follow-up visits were assessed periodically over the course of } \\
\text { the trial by expert malaria microscopists" }\end{array}$ \\
\hline & & $\begin{array}{l}\text { Safety outcomes: Quote: "The Data and Safety Monitoring Board did a blinded } \\
\text { safety review every } 6 \text { months" }\end{array}$ \\
\hline $\begin{array}{l}\text { Incomplete outcome data } \\
\text { (attrition bias) } \\
\text { All outcomes }\end{array}$ & Unclear risk & $\begin{array}{l}\text { Available case analysis, attrition after one year was } 32 \% \text { (297/935) in } 7 \text {-day pri- } \\
\text { maquine group and } 29 \% \text { (270/937) in 14-day primaquine group, reasons for } \\
\text { leaving the study early were reported. }\end{array}$ \\
\hline $\begin{array}{l}\text { Selective reporting (re- } \\
\text { porting bias) }\end{array}$ & Low risk & $\begin{array}{l}\text { Protocol and online trial registry were checked; all outcomes and sensitivity } \\
\text { analyses were reported. }\end{array}$ \\
\hline
\end{tabular}


Taylor 2019 MULTI (Continued)
Other bias
Low risk
We did not detect any other sources of bias.

Abbreviations: ACT: artemisinin-based combination therapy; CQ: chloroquine; CYP2D6: cytochrome P450 2D6; G6PD: glucose-6-phosphate dehydrogenase; PCR: polymerase chain reaction; PCR-RFLP: polymerase chain reaction-restriction fragment length polymorphism; PQ: primaquine; RCT: randomized controlled trial; SE: standard error; SR: sustained release; WHO: World Health Organization.

Characteristics of excluded studies [ordered by study ID]

\begin{tabular}{|c|c|}
\hline Study & Reason for exclusion \\
\hline Adak 2001 & No PQ comparison group. \\
\hline Alvarez 2006 & $\begin{array}{l}\text { Comparison regimens are of a lower total dose than the control ( } 15 \mathrm{mg} / \text { day for } 3 \text { days or } 7 \text { days) - } \\
\text { shown to be inferior in Galappaththy } 2013 .\end{array}$ \\
\hline Alvarez Sanchez 2007 & Low-dose, shorter regimens of $\mathrm{PQ}$. \\
\hline Betuela 2012 & Only one treatment group received primaquine. \\
\hline Chu 2017 & $\begin{array}{l}\text { Wrong outcomes: primary outcome of this analysis was the fractional haematocrit reduction up to } \\
\text { day } 14 \text { after enrolment. }\end{array}$ \\
\hline Chu 2018 & No primaquine comparison arm. \\
\hline Clyde 1977 & Not an RCT, observational single-arm trial. \\
\hline Contacos 1974 & Not an RCT. \\
\hline da Silva 1984 & $\begin{array}{l}\text { Not properly randomized (randomized according to whether the end of the notes code is odd or } \\
\text { even), low-dose comparison PQ group. }\end{array}$ \\
\hline Daher 2018 & $\begin{array}{l}\text { Wrong comparator: same dose primaquine in all treatment arms (two tablets of } 15 \mathrm{mg} P Q \text { for } 7,8 \text { or } \\
9 \text { days, total dose between } 3.0 \text { and } 4.2 \mathrm{mg} / \mathrm{kg} \text { ). }\end{array}$ \\
\hline Gogtay 1999 & Low-dose $15 \mathrm{mg}$ for shorter time period (5 days) - shown to be ineffective in Galappaththy 2013. \\
\hline Goller 2007 & $\begin{array}{l}\text { Not an RCT - logistic regression using already-published RCTs and observational studies (not pri- } \\
\text { mary trial). }\end{array}$ \\
\hline Hamid 2018 & $\begin{array}{l}\text { Wrong comparator: Artesunate and Sulphadoxine/pyrimethamine + concomitant versus delayed } \\
\text { 14-day primaquine. }\end{array}$ \\
\hline Kim 2012 & Wrong comparator: low-dose for 5 days - shown to be ineffective in Galappaththy 2013. \\
\hline Kimura 1996 & Not an RCT. \\
\hline Krudsood 2008 & $\begin{array}{l}\text { Artesunate only as blood-stage treatment (does not meet inclusion criteria) and follow-up only } 28 \\
\text { days. }\end{array}$ \\
\hline Ladeia-Andrade 2019 & $\begin{array}{l}\text { Wrong comparator: concomitant versus delayed regimen (chloroquine with primaquine } 0.5 \mathrm{mg} / \mathrm{kg} \\
\text { once a day, for seven days (total dose, } 3.5 \mathrm{mg} / \mathrm{kg} \text { ) versus chloroquine with primaquine introduced } \\
\text { on day } 28\end{array}$ \\
\hline Leslie 2004 & No PQ comparison group: supervised versus unsupervised therapy. \\
\hline
\end{tabular}




\begin{tabular}{|c|c|}
\hline Study & Reason for exclusion \\
\hline Leslie 2008b & $\begin{array}{l}\text { Duplicate of Leslie } 2008 \text { PAK; conference abstract title only for session at ASTMH 57th Annual Meet- } \\
\text { ing. }\end{array}$ \\
\hline Maneeboonyang 2011 & $\begin{array}{l}\text { Not randomized, participants were sequentially allocated into either the directly observed thera- } \\
\text { py (DOT) group or the self-administered therapy (SAT) group. No PQ comparison group, supervised } \\
\text { versus non-supervised therapy. }\end{array}$ \\
\hline Miller 1974 & Not an RCT. \\
\hline Moore 2018 & Not an RCT \\
\hline Pasaribu 2013 & No PQ comparison group. \\
\hline Pukrittayakamee 2000 & No PQ comparison group. \\
\hline Sabchareon 1981 & $\begin{array}{l}\text { No blood-stage antimalarial treatment used in primaquine comparison group according to inclu- } \\
\text { sion criteria. }\end{array}$ \\
\hline Saint-Yves IF 1977 & Presumptive treatment of $45 \mathrm{mg}$ PQ given to all participants before randomization. \\
\hline Takeuchi 2010 & No PQ comparison group: supervised versus non-supervised therapy. \\
\hline Villalobos-Salcedo 2000 & $\begin{array}{l}\text { Wrong comparator: lower dose of PQ in comparison group (total dose } 150 \mathrm{mg} \text { ) - shown to be inef- } \\
\text { fective in Galappaththy } 2013 \text {. }\end{array}$ \\
\hline Warrasak 2019 & No primaquine comparison arm, ophthalmological outcomes. \\
\hline
\end{tabular}

Abbreviations: PQ: primaquine; RCT: randomized controlled trial.

Characteristics of ongoing studies [ordered by study ID]

\section{NCT01837992}

Study name
Evaluation of safety and efficacy of two primaquine dosing regimens for the radical treatment of Plasmodium vivax malaria in Vanuatu and Solomon Islands 
NCT01837992 (Continued)

- Residence or planned travel outside the study area during the follow-up period (precluding supervised treatment and follow-up procedures).

- Known or suspected pregnancy.

- Currently breastfeeding.

- A positive rapid test for G6PD deficiency (Binax or Carestart RDT).
1. Primaquine dose of $0.5 \mathrm{mg} / \mathrm{kg} / \mathrm{day}$ for 14 consecutive days and standard age-based dosage 3 day course of artemether-lumefantrine

2. Primaquine dose of $0.25 \mathrm{mg} / \mathrm{kg}$ for 14 consecutive days and standard age-based dosage 3-day course of artemether-lumefantrine

(3. Participants will receive a standard 3-day treatment course of artemether-lumefantrine at the standard age-based dosage, but will not receive primaquine until the time of confirmed recurrent parasitaemia or completion of 3 months follow-up)

\begin{tabular}{ll}
\hline Starting date & May 2013 \\
\hline Contact information & Dr Ivo Mueller; mueller@wehi.edu.au \\
\hline Notes & Estimated completion date May 2015. Contacted for results - no response. \\
& Protocol available at clinicaltrials.gov/ct2/show/NCT01837992 \\
\hline
\end{tabular}

Abbreviations: G6PD: glucose-6-phosphate dehydrogenase; Hb: haemoglobin; PCR: polymerase chain reaction; RCT: randomized controlled trial; RDT: rapid diagnostic test; WHO: World Health Organization.

\section{DATA AND ANALYSES}

\section{Comparison 1. $0.5 \mathrm{mg} / \mathrm{kg} /$ day 7 days versus standard $0.25 \mathrm{mg} / \mathrm{kg} / \mathrm{day} 14$ days}

\begin{tabular}{|c|c|c|c|c|}
\hline Outcome or subgroup title & $\begin{array}{l}\text { No. of } \\
\text { studies }\end{array}$ & $\begin{array}{l}\text { No. of } \\
\text { partici- } \\
\text { pants }\end{array}$ & Statistical method & Effect size \\
\hline $\begin{array}{l}\text { 1.1 Recurrence by } 6 \text { to } 7 \text { months' fol- } \\
\text { low-up }\end{array}$ & 4 & 1211 & Risk Ratio (M-H, Fixed, 95\% Cl) & $0.96[0.66,1.39]$ \\
\hline $\begin{array}{l}\text { 1.2 Recurrence by } 6 \text { to } 7 \text { months' fol- } \\
\text { low-up (PCR-adjusted) }\end{array}$ & 2 & & Risk Ratio (M-H, Fixed, 95\% Cl) & Subtotals only \\
\hline $\begin{array}{l}1.3 \text { Recurrence by } 6 \text { to } 7 \text { months sub- } \\
\text { grouped by geographical region }\end{array}$ & 4 & 1211 & Risk Ratio (M-H, Fixed, 95\% Cl) & $0.96[0.66,1.39]$ \\
\hline 1.3.1 South America & 2 & 397 & Risk Ratio (M-H, Fixed, 95\% Cl) & $0.70[0.39,1.26]$ \\
\hline 1.3.2 Asia & 2 & 814 & Risk Ratio (M-H, Fixed, 95\% Cl) & $1.19[0.73,1.94]$ \\
\hline
\end{tabular}

Primaquine alternative dosing schedules for preventing malaria relapse in people with Plasmodium vivax (Review) 


\begin{tabular}{|c|c|c|c|c|}
\hline Outcome or subgroup title & $\begin{array}{l}\text { No. of } \\
\text { studies }\end{array}$ & $\begin{array}{l}\text { No. of } \\
\text { partici- } \\
\text { pants }\end{array}$ & Statistical method & Effect size \\
\hline $\begin{array}{l}\text { 1.4 Recurrence by } 6 \text { to } 7 \text { months sub- } \\
\text { grouped by directly observed therapy } \\
\text { (DOT) versus non-DOT }\end{array}$ & 4 & 1211 & Risk Ratio (M-H, Fixed, 95\% Cl) & $0.96[0.66,1.39]$ \\
\hline 1.4.1 DOT & 3 & 1017 & Risk Ratio (M-H, Fixed, 95\% Cl) & $0.98[0.67,1.43]$ \\
\hline 1.4.2 Non-DOT & 1 & 194 & Risk Ratio (M-H, Fixed, 95\% Cl) & $0.48[0.04,5.20]$ \\
\hline 1.5 Serious adverse events & 5 & 1427 & Risk Ratio (M-H, Fixed, 95\% Cl) & Not estimable \\
\hline $\begin{array}{l}\text { 1.6 Adverse events that result in discon- } \\
\text { tinuation of treatment }\end{array}$ & 5 & 1427 & Risk Ratio (M-H, Fixed, 95\% Cl) & $1.04[0.15,7.38]$ \\
\hline $\begin{array}{l}\text { 1.7 Adverse events during chloroquine } \\
\text { administration }\end{array}$ & 1 & 779 & Risk Ratio (M-H, Fixed, 95\% Cl) & $9.40[0.51,174.01]$ \\
\hline $\begin{array}{l}\text { 1.8 Adverse effects during primaquine } \\
\text { administration }\end{array}$ & 2 & 1019 & Risk Ratio (M-H, Fixed, 95\% Cl) & $1.64[0.75,3.57]$ \\
\hline 1.9 Other adverse events & 2 & 135 & Risk Ratio (M-H, Fixed, 95\% Cl) & $0.56[0.23,1.36]$ \\
\hline $\begin{array}{l}\text { 1.10 Anaemia or change in haemoglobin } \\
\text { status }\end{array}$ & 1 & 240 & Risk Ratio (M-H, Fixed, 95\% Cl) & $3.00[0.12,72.91]$ \\
\hline
\end{tabular}

\section{Analysis 1.1. Comparison $1: 0.5 \mathrm{mg} / \mathrm{kg} /$ day 7 days versus standard 0.25 $\mathrm{mg} / \mathrm{kg} /$ day 14 days, Outcome 1: Recurrence by 6 to 7 months' follow-up}

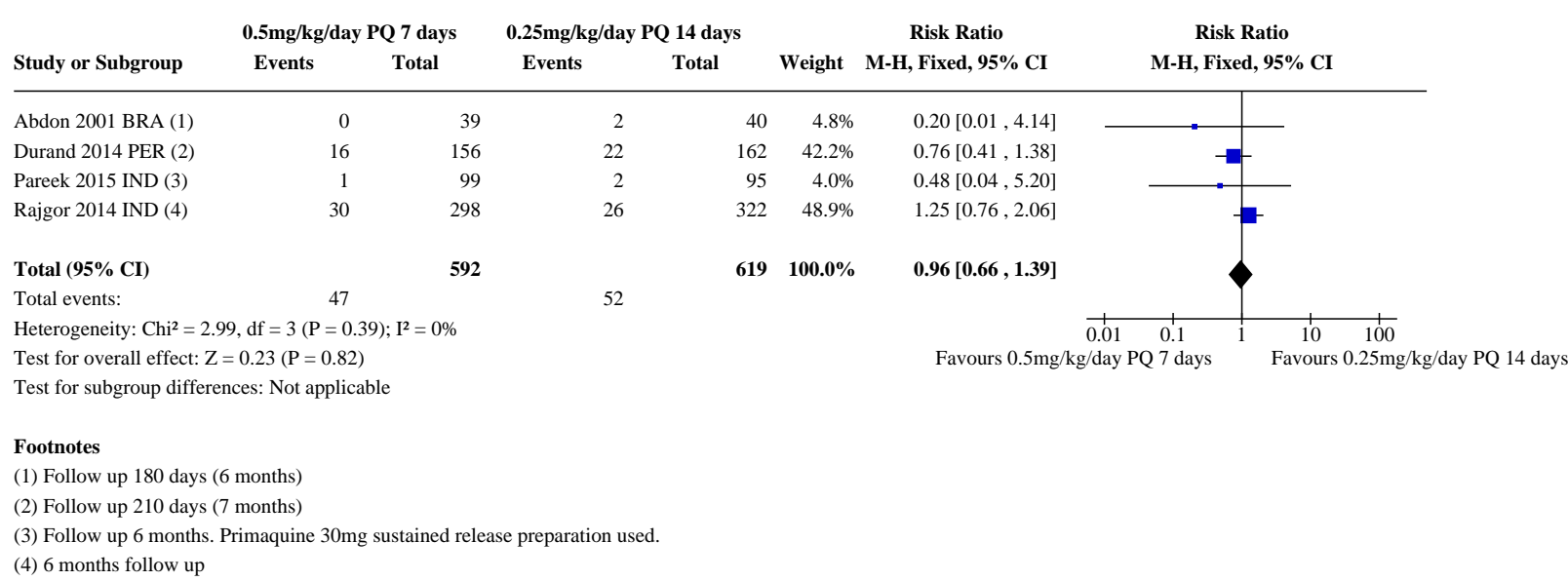


Analysis 1.2. Comparison $1: 0.5 \mathrm{mg} / \mathrm{kg} /$ day 7 days versus standard $0.25 \mathrm{mg} / \mathrm{kg} /$ day 14 days, Outcome 2: Recurrence by 6 to 7 months' follow-up (PCR-adjusted)

\begin{tabular}{|c|c|c|c|c|c|c|c|c|}
\hline \multirow{3}{*}{$\begin{array}{l}\text { Study or Subgroup } \\
\text { Durand } 2014 \text { PER (1) }\end{array}$} & \multicolumn{2}{|c|}{$0.5 \mathrm{mg} / \mathrm{kg} / \mathrm{day} P Q 7$ days } & \multicolumn{2}{|c|}{$0.25 \mathrm{mg} / \mathrm{kg} / \mathrm{day} \mathrm{PQ} 14$ days } & \multirow{2}{*}{$\begin{array}{c}\text { Risk Ratio } \\
\text { M-H, Fixed, 95\% CI }\end{array}$} & \multirow{2}{*}{\multicolumn{2}{|c|}{$\begin{array}{c}\text { Risk Ratio } \\
\text { M-H, Fixed, 95\% CI }\end{array}$}} & \\
\hline & Events & Total & Events & Total & & & & \\
\hline & 8 & 156 & 12 & 162 & $0.69[0.29,1.65]$ & $\longrightarrow$ & - & \\
\hline Rajgor 2014 IND (2) & 12 & 298 & 5 & 322 & $2.59[0.92,7.27]$ & & 1- & \\
\hline \multicolumn{5}{|c|}{ Test for subgroup differences: Not applicable } & Favours $0.5 \mathrm{mg} /$ & $\begin{array}{l}0.1 \\
Q 7 \text { days }\end{array}$ & $\begin{array}{c}10 \\
\text { Favours }\end{array}$ & $\begin{array}{l}100 \\
5 \mathrm{mg} / \mathrm{k}\end{array}$ \\
\hline
\end{tabular}

Footnotes

(1) Follow up 210 days (7 months)

(2) Follow up 6 months

Analysis 1.3. Comparison 1: $0.5 \mathrm{mg} / \mathrm{kg} /$ day 7 days versus standard $0.25 \mathrm{mg} / \mathrm{kg} / \mathrm{day}$ 14 days, Outcome 3: Recurrence by 6 to 7 months subgrouped by geographical region

\begin{tabular}{|c|c|c|c|c|c|c|c|}
\hline & $0.5 \mathrm{mg} / \mathrm{kg}$ & Q 7 days & $0.25 \mathrm{mg} / \mathrm{k}$ & Q 14 days & & Risk Ratio & Risk Ratio \\
\hline Study or Subgroup & Events & Total & Events & Total & Weight & M-H, Fixed, 95\% CI & M-H, Fixed, 95\% CI \\
\hline
\end{tabular}

1.3.1 South America

Abdon 2001 BRA

Durand 2014 PER

Subtotal $(95 \%$ CI)

Total events:

Heterogeneity: $\mathrm{Chi}^{2}=0.70, \mathrm{df}=1(\mathrm{P}=0.40) ; \mathrm{I}^{2}=0 \%$

Test for overall effect: $\mathrm{Z}=1.19(\mathrm{P}=0.23)$

\subsubsection{Asia}

Pareek 2015 IND

Rajgor 2014 IND

Subtotal (95\% CI)

Total events:

Heterogeneity: $\mathrm{Chi}^{2}=0.59, \mathrm{df}=1(\mathrm{P}=0.44) ; \mathrm{I}^{2}=0 \%$

Test for overall effect: $\mathrm{Z}=0.69(\mathrm{P}=0.49)$

Total $(95 \% \mathrm{CI})$

Total events:

592

Heterogeneity: $\mathrm{Chi}^{2}=2.99, \mathrm{df}=3(\mathrm{P}=0.39) ; \mathrm{I}^{2}=0 \%$

Test for overall effect: $\mathrm{Z}=0.23(\mathrm{P}=0.82)$

Test for subgroup differences: $\mathrm{Chi}^{2}=1.86, \mathrm{df}=1(\mathrm{P}=0.17), \mathrm{I}^{2}=46.1 \%$

$\begin{array}{rrr}95 & 4.0 \% & 0.48[0.04,5.20] \\ 322 & 48.9 \% & 1.25[0.76,2.06] \\ \mathbf{4 1 7} & \mathbf{5 2 . 9 \%} & \mathbf{1 . 1 9}[\mathbf{0 . 7 3}, \mathbf{1 . 9 4}]\end{array}$

$0.20[0.01,4.14]$

$0.76[0.41,1.38]$

$0.70[0.39,1.26]$

$162 \quad 42.2 \%$

$202 \quad 47.1 \%$

24

$417 \quad 52.9 \%$

$1.19[0.73,1.94]$

28

$\longrightarrow$

Primaquine alternative dosing schedules for preventing malaria relapse in people with Plasmodium vivax (Review) 
Analysis 1.4. Comparison $1: 0.5 \mathrm{mg} / \mathrm{kg} /$ day 7 days versus standard $0.25 \mathrm{mg} / \mathrm{kg} /$ day 14 days, Outcome 4: Recurrence by 6 to 7 months subgrouped by directly observed therapy (DOT) versus non-DOT

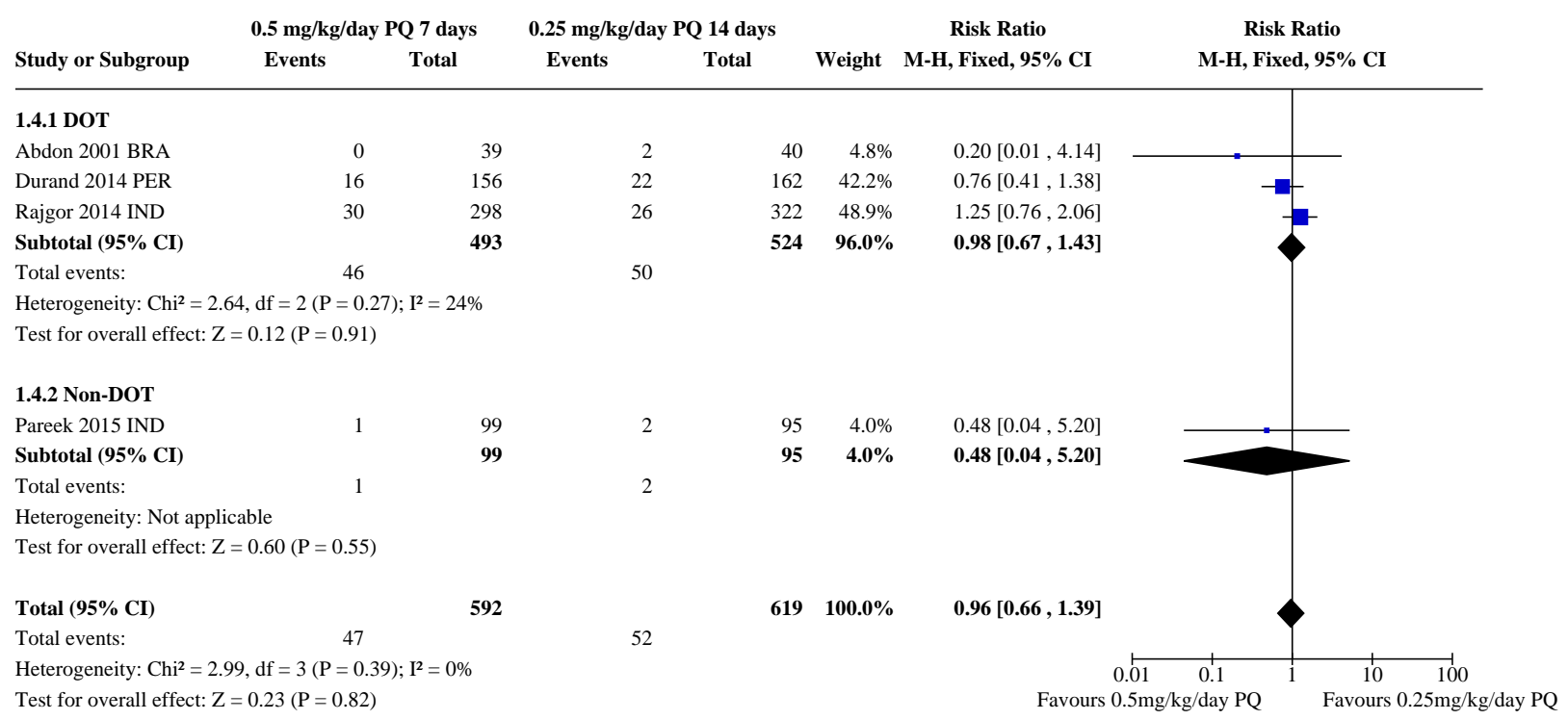

Analysis 1.5. Comparison $1: 0.5 \mathrm{mg} / \mathrm{kg} / \mathrm{day} 7$ days versus standard $0.25 \mathrm{mg} / \mathrm{kg} /$ day 14 days, Outcome 5: Serious adverse events

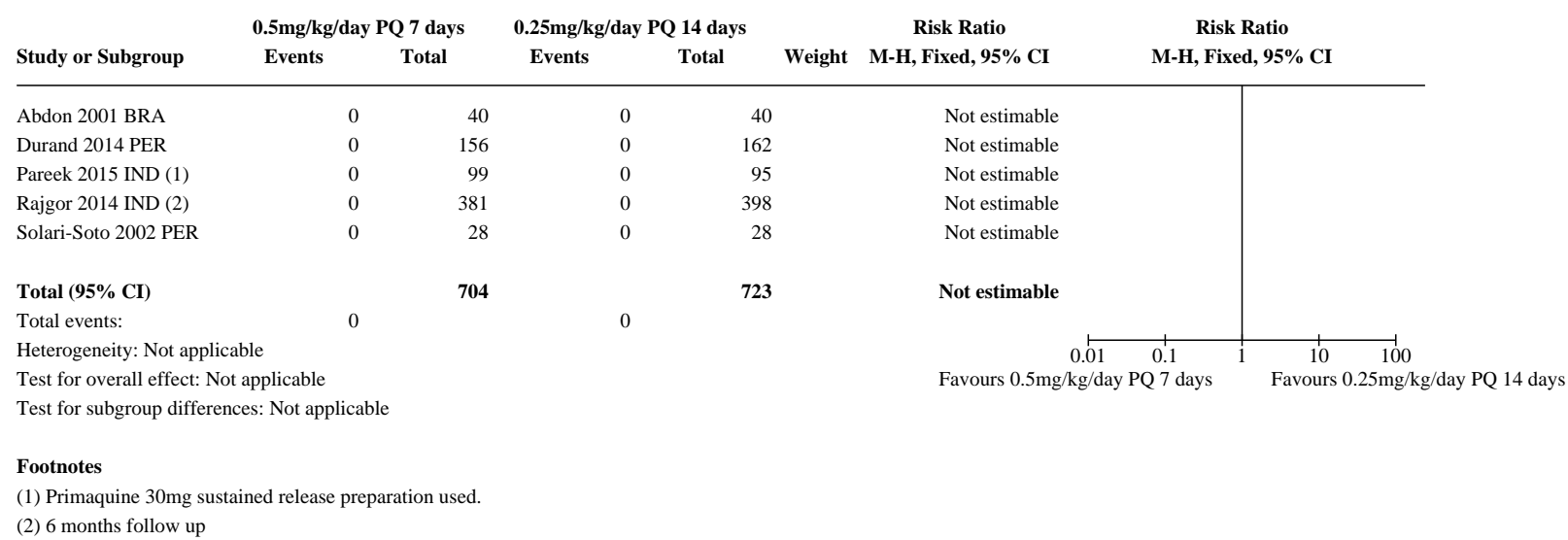


Analysis 1.6. Comparison $1: 0.5 \mathrm{mg} / \mathrm{kg} / \mathrm{day} 7$ days versus standard $0.25 \mathrm{mg} / \mathrm{kg} /$ day 14 days, Outcome 6: Adverse events that result in discontinuation of treatment

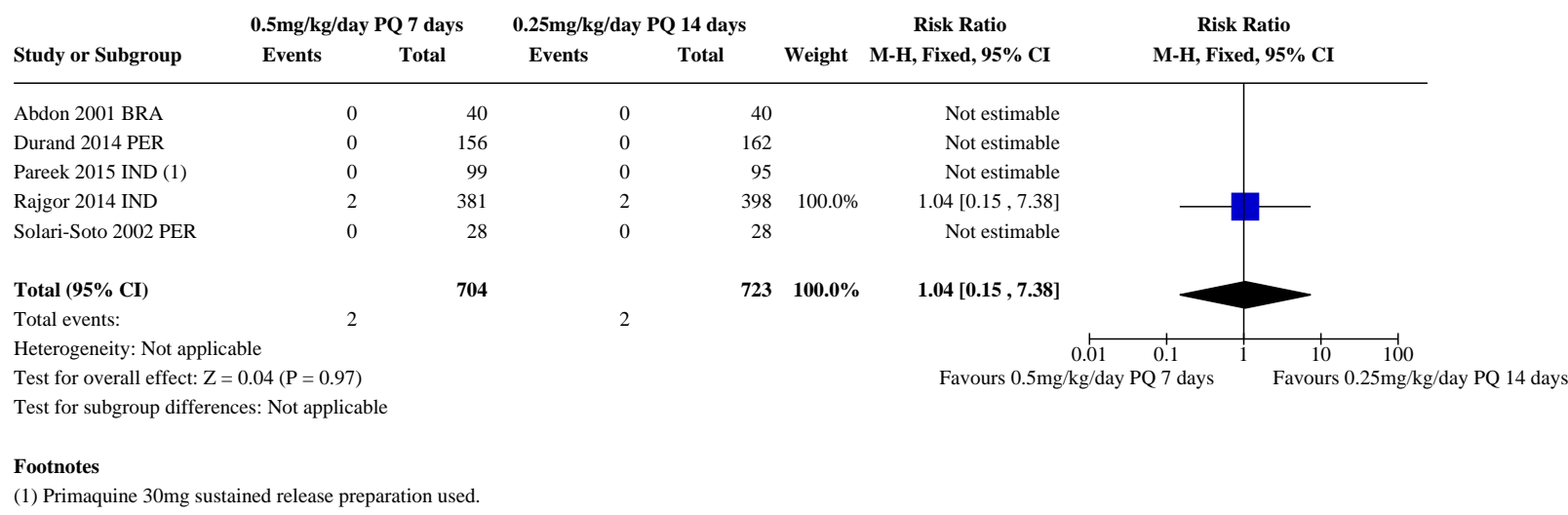

Analysis 1.7. Comparison $1: 0.5 \mathrm{mg} / \mathrm{kg} /$ day 7 days versus standard $0.25 \mathrm{mg} /$ $\mathrm{kg} /$ day 14 days, Outcome 7: Adverse events during chloroquine administration

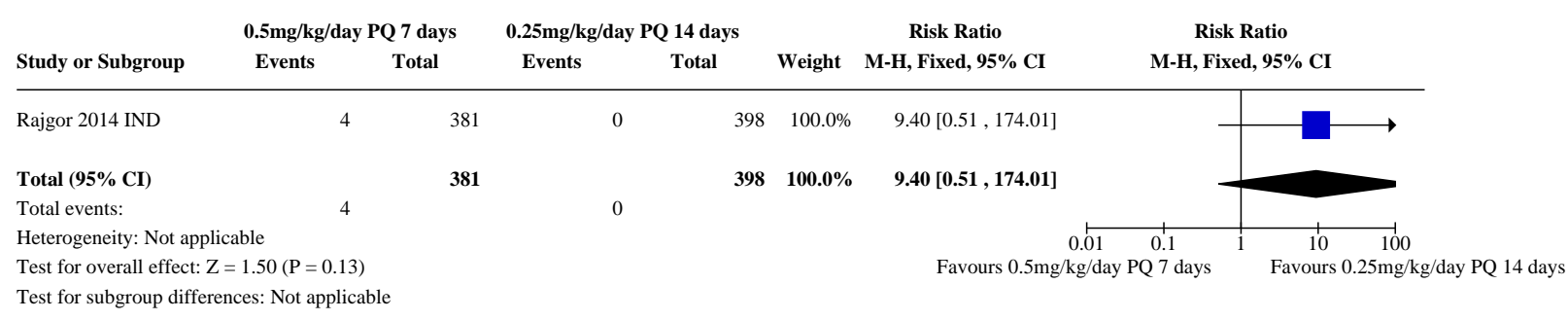

Analysis 1.8. Comparison $1: 0.5 \mathrm{mg} / \mathrm{kg} /$ day 7 days versus standard $0.25 \mathrm{mg} /$ $\mathrm{kg} /$ day 14 days, Outcome 8: Adverse effects during primaquine administration

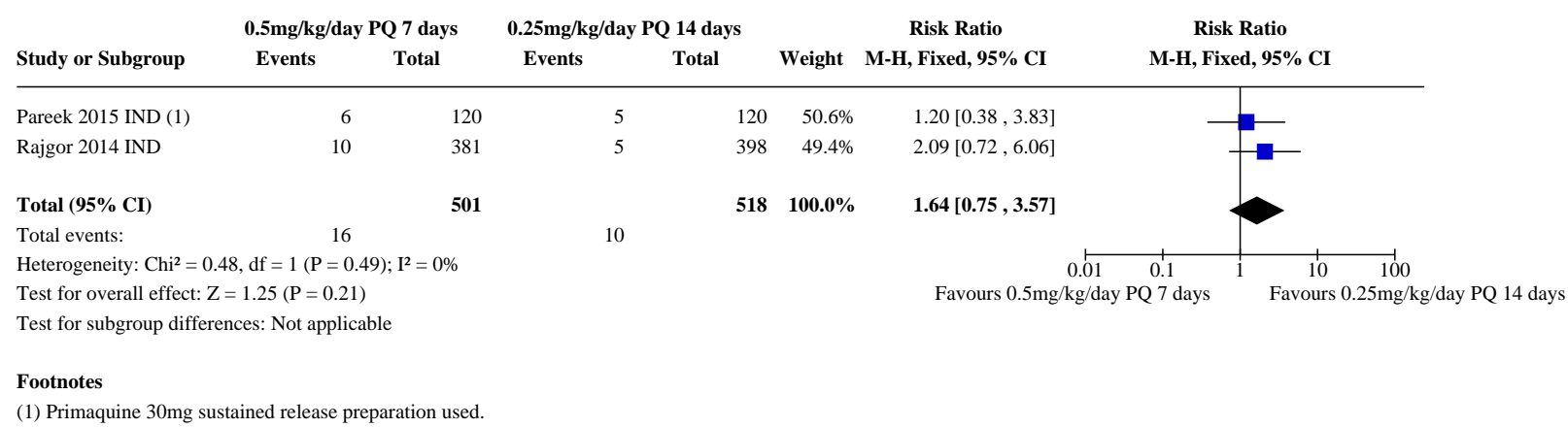




\section{Analysis 1.9. Comparison $1: 0.5 \mathrm{mg} / \mathrm{kg} /$ day 7 days versus standard} $0.25 \mathrm{mg} / \mathrm{kg} /$ day 14 days, Outcome 9: Other adverse events

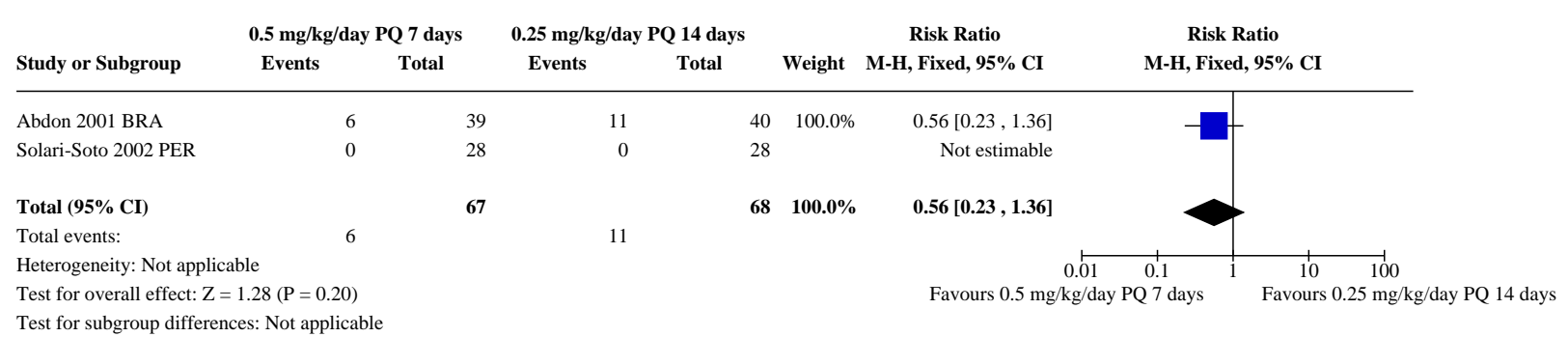

\section{Analysis 1.10. Comparison $1: 0.5 \mathrm{mg} / \mathrm{kg} /$ day 7 days versus standard $0.25 \mathrm{mg} /$ $\mathrm{kg} /$ day 14 days, Outcome 10: Anaemia or change in haemoglobin status}

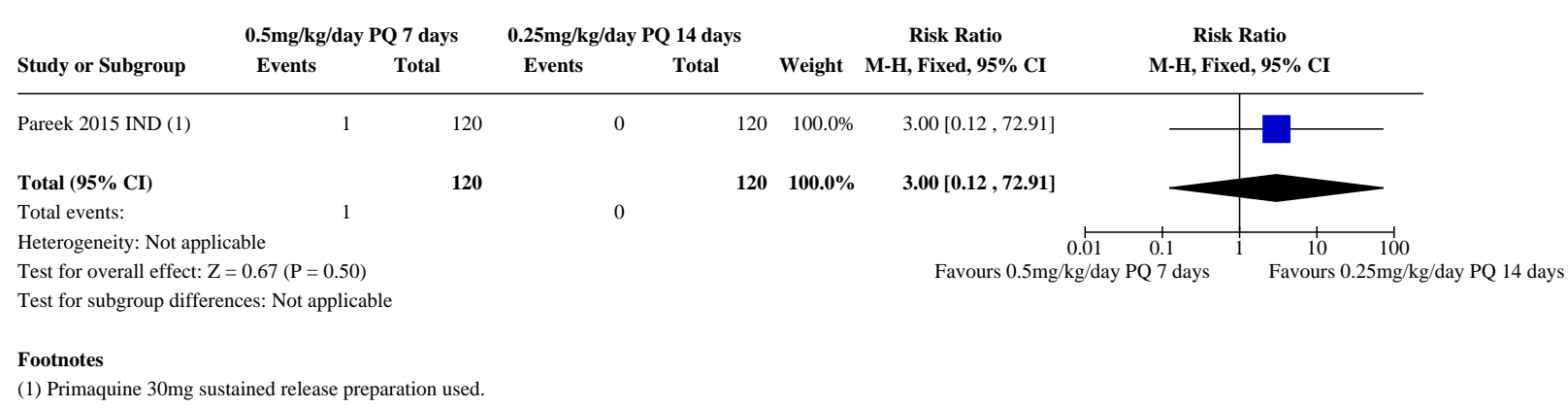

Comparison 2. High-standard $0.5 \mathrm{mg} / \mathrm{kg} /$ day 14 days versus standard $0.25 \mathrm{mg} / \mathrm{kg} /$ day 14 days

\begin{tabular}{|c|c|c|c|c|}
\hline Outcome or subgroup title & $\begin{array}{l}\text { No. of } \\
\text { studies }\end{array}$ & $\begin{array}{l}\text { No. of } \\
\text { partici- } \\
\text { pants }\end{array}$ & Statistical method & Effect size \\
\hline 2.1 Recurrence by 6 months' follow-up & 2 & 677 & Risk Ratio (M-H, Fixed, 95\% Cl) & $0.84[0.49,1.43]$ \\
\hline $\begin{array}{l}2.1 .16 \text { months (chloroquine blood-stage } \\
\text { treatment) }\end{array}$ & 1 & 639 & Risk Ratio (M-H, Fixed, 95\% Cl) & $0.82[0.47,1.43]$ \\
\hline $\begin{array}{l}\text { 2.1.2 } 6 \text { months (chloroquine or ACT } \\
\text { blood-stage treatment) }\end{array}$ & 1 & 38 & Risk Ratio (M-H, Fixed, 95\% Cl) & $1.11[0.17,7.09]$ \\
\hline $\begin{array}{l}2.2 \text { Recurrence by } 6 \text { months' follow-up } \\
\text { (PCR-adjusted) }\end{array}$ & 1 & & Risk Ratio (M-H, Fixed, 95\% Cl) & Subtotals only \\
\hline 2.3 Serious adverse events & 1 & 778 & Risk Ratio (M-H, Fixed, 95\% Cl) & Not estimable \\
\hline $\begin{array}{l}\text { 2.4 Adverse events that result in discon- } \\
\text { tinuation of treatment }\end{array}$ & 1 & 778 & Risk Ratio (M-H, Fixed, 95\% Cl) & $4.19[0.90,19.60]$ \\
\hline 2.5 Other adverse events & 1 & & Risk Ratio (M-H, Fixed, 95\% Cl) & Totals not selected \\
\hline 2.5.1 AEs during chloroquine treatment & 1 & & Risk Ratio (M-H, Fixed, 95\% Cl) & Totals not selected \\
\hline 2.5.2 AEs during primaquine treatment & 1 & & Risk Ratio (M-H, Fixed, 95\% Cl) & Totals not selected \\
\hline
\end{tabular}


Analysis 2.1. Comparison 2: High-standard $0.5 \mathrm{mg} / \mathrm{kg} / \mathrm{day} 14$ days versus standard $0.25 \mathrm{mg} / \mathrm{kg} /$ day 14 days, Outcome 1: Recurrence by 6 months' follow-up

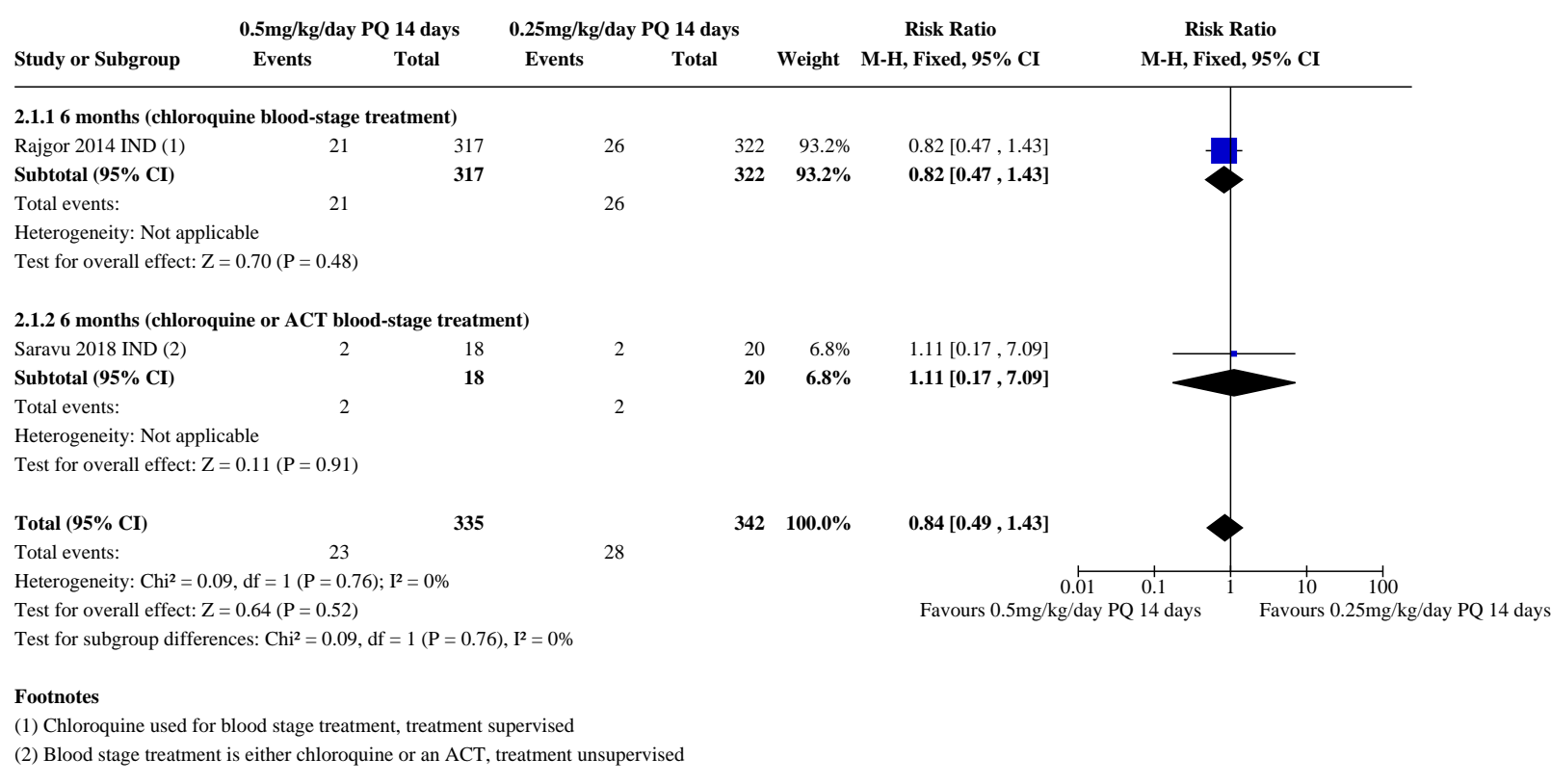

Analysis 2.2. Comparison 2: High-standard $0.5 \mathrm{mg} / \mathrm{kg} /$ day 14 days versus standard $0.25 \mathrm{mg} / \mathrm{kg} /$ day 14 days, Outcome 2: Recurrence by 6 months' follow-up (PCR-adjusted)

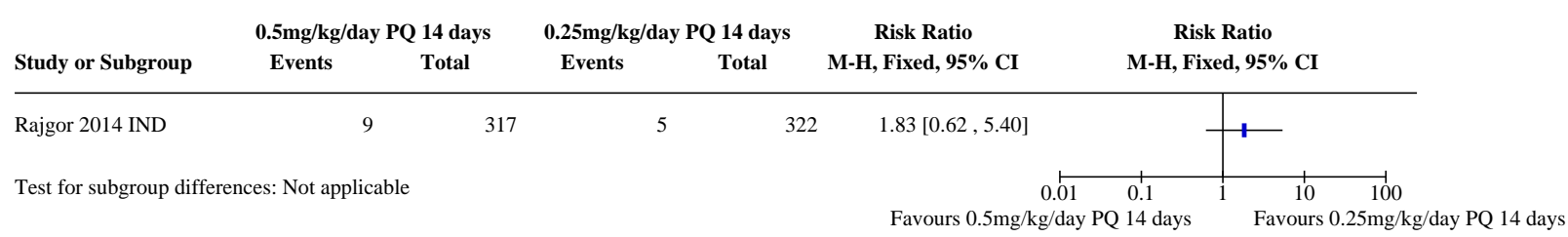

\section{Analysis 2.3. Comparison 2: High-standard $0.5 \mathrm{mg} / \mathrm{kg} / \mathrm{day} 14$ days versus standard $0.25 \mathrm{mg} / \mathrm{kg} /$ day 14 days, Outcome 3: Serious adverse events}

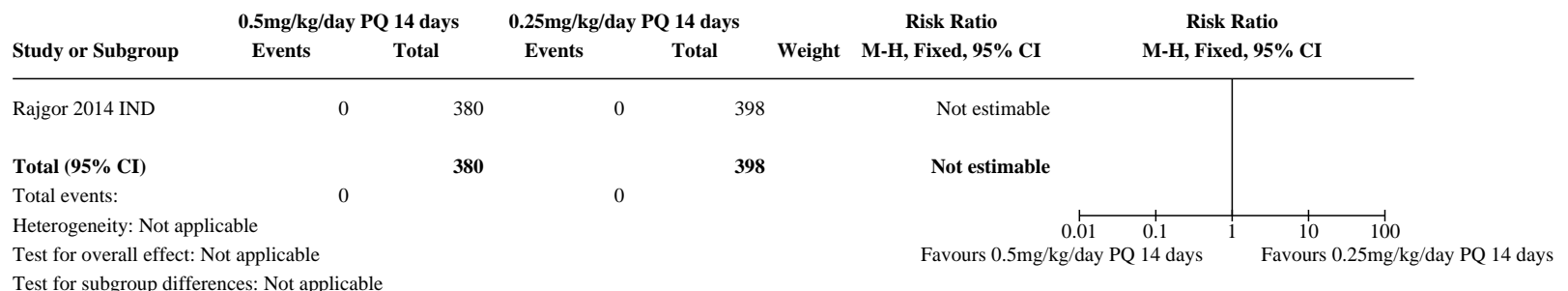


Analysis 2.4. Comparison 2: High-standard $0.5 \mathrm{mg} / \mathrm{kg} / \mathrm{day} 14$ days versus standard 0.25 $\mathrm{mg} / \mathrm{kg} /$ day 14 days, Outcome 4: Adverse events that result in discontinuation of treatment

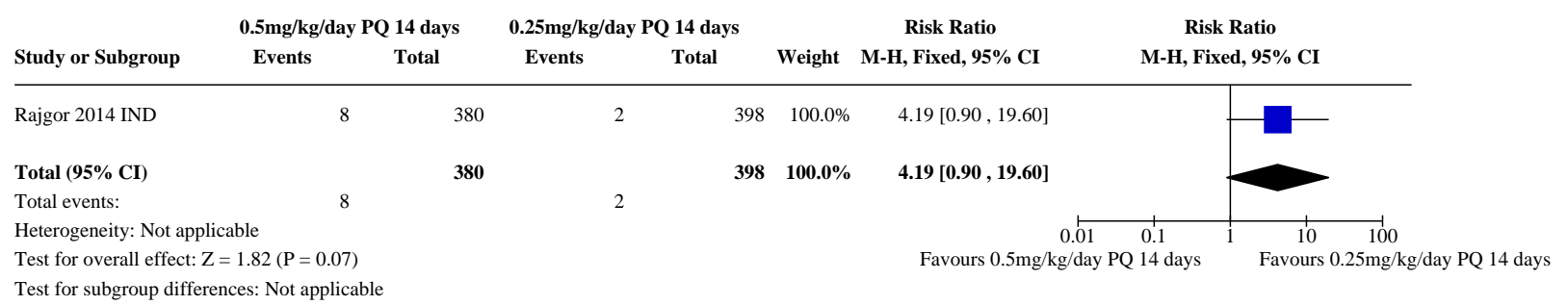

Test for subgroup differences: Not applicable

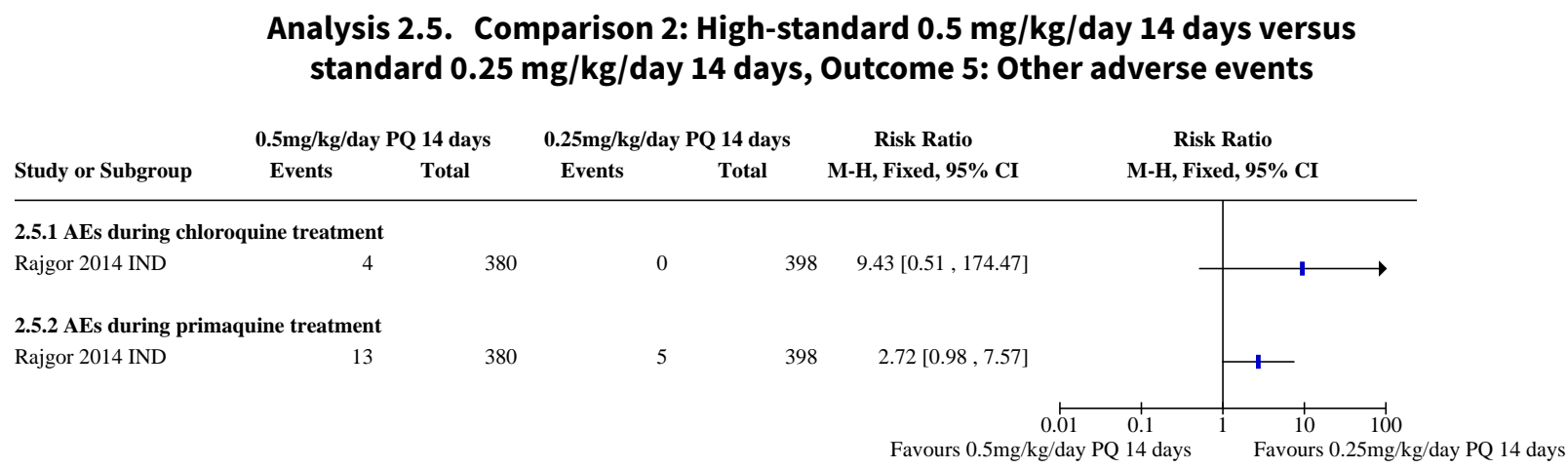

Comparison 3. $0.75 \mathrm{mg} / \mathrm{kg} /$ week 8 weeks versus high-standard $0.5 \mathrm{mg} / \mathrm{kg} /$ day 14 days

\begin{tabular}{lllll}
\hline Outcome or subgroup title & $\begin{array}{l}\text { No. of } \\
\text { studies }\end{array}$ & $\begin{array}{l}\text { No. of } \\
\text { partici- } \\
\text { pants }\end{array}$ & Statistical method & Effect size \\
\hline 3.1 Recurrence & 1 & & Risk Ratio (M-H, Fixed, 95\% Cl) & Subtotals only \\
\hline 3.1.1 5 months & 1 & 129 & Risk Ratio (M-H, Fixed, 95\% Cl) & $5.23[0.28,99.15]$ \\
\hline 3.1 .28 months & 1 & 126 & Risk Ratio (M-H, Fixed, 95\% Cl) & $7.00[0.38,127.32]$ \\
\hline 3.1.3 11 months & 1 & 122 & Risk Ratio (M-H, Fixed, 95\% Cl) & $3.18[0.37,27.60]$ \\
\hline 3.2 Serious adverse events & 1 & 129 & Risk Ratio (M-H, Fixed, 95\% Cl) & Not estimable \\
\hline $\begin{array}{l}\text { 3.3 Anaemia (haemoglobin }<7 \mathrm{~g} / \\
\mathrm{dL})\end{array}$ & 1 & 129 & Risk Ratio (M-H, Fixed, 95\% Cl) & Not estimable \\
\hline 3.4 Other adverse events & 1 & 129 & Risk Ratio (M-H, Fixed, 95\% Cl) & Not estimable \\
\hline
\end{tabular}


Analysis 3.1. Comparison $3: 0.75 \mathrm{mg} / \mathrm{kg} /$ week 8 weeks versus high-standard $0.5 \mathrm{mg} / \mathrm{kg} /$ day 14 days, Outcome 1: Recurrence

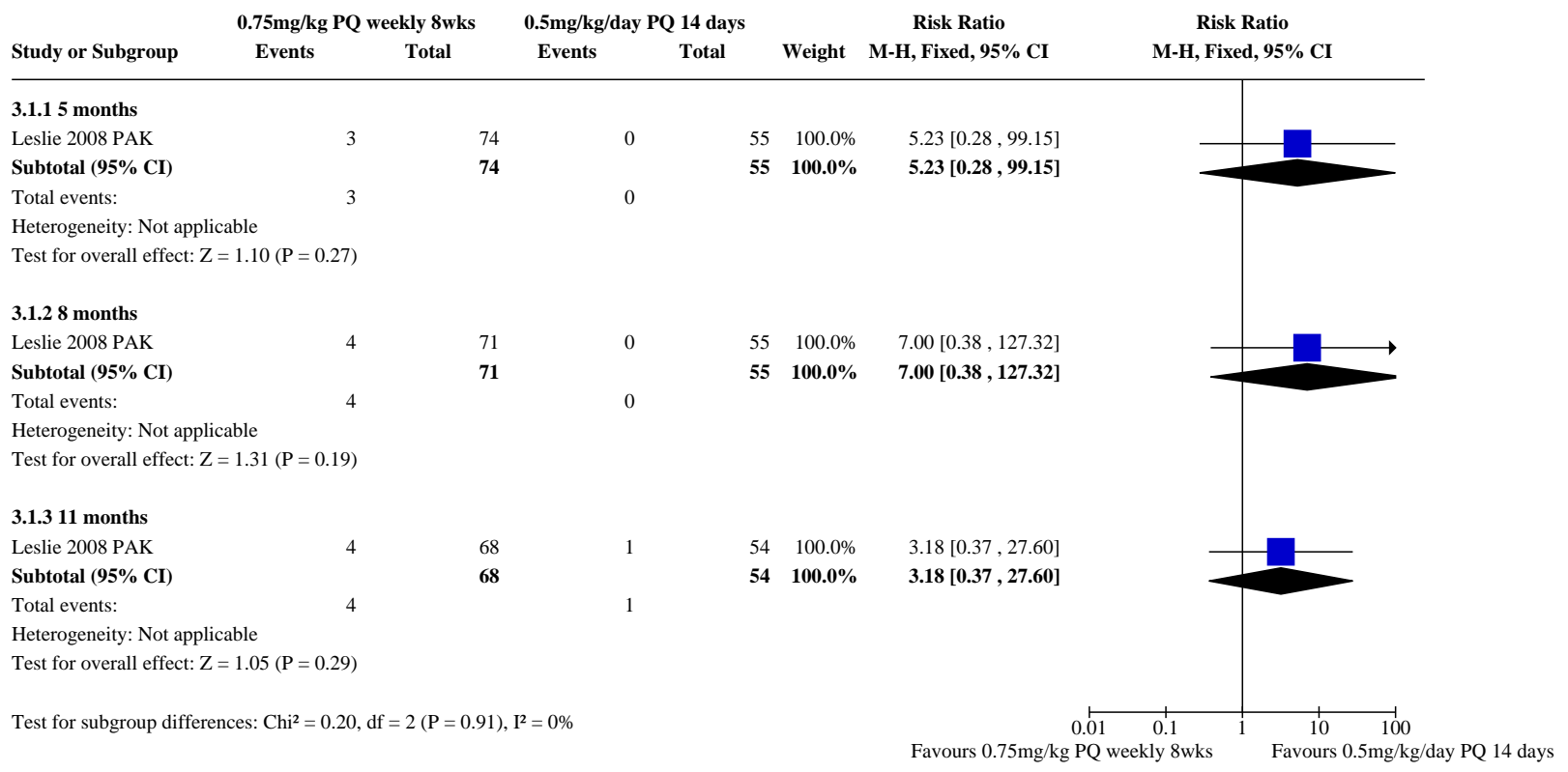

Analysis 3.2. Comparison $3: 0.75 \mathrm{mg} / \mathrm{kg} /$ week 8 weeks versus highstandard $0.5 \mathrm{mg} / \mathrm{kg} /$ day 14 days, Outcome 2: Serious adverse events

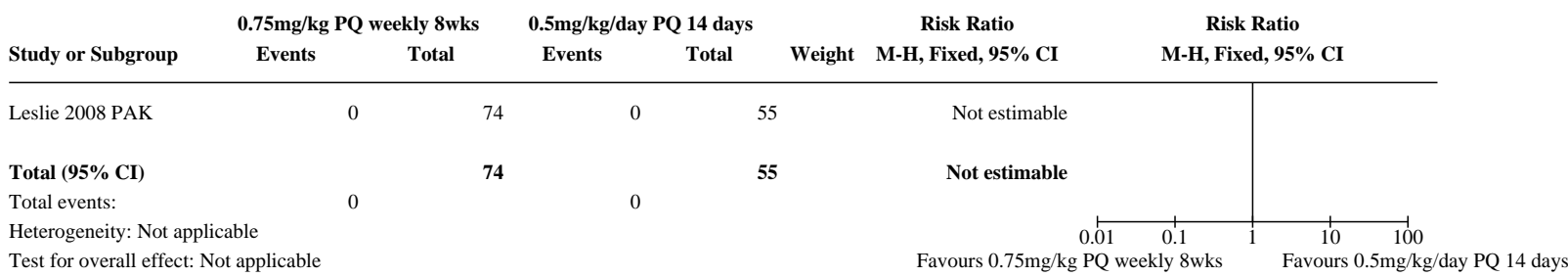

Test for subgroup differences: Not applicable

Analysis 3.3. Comparison $3: 0.75 \mathrm{mg} / \mathrm{kg} /$ week 8 weeks versus highstandard $0.5 \mathrm{mg} / \mathrm{kg} /$ day 14 days, Outcome 3: Anaemia (haemoglobin $<7 \mathrm{~g} / \mathrm{dL}$ )

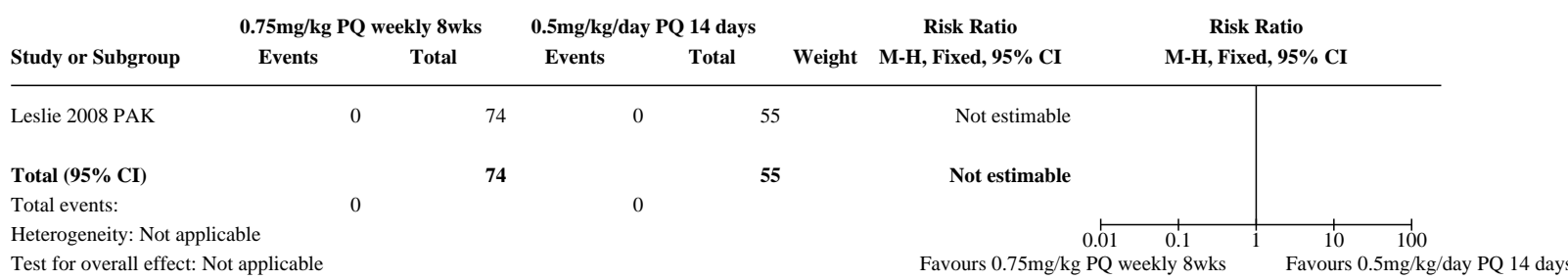

Test for subgroup differences: Not applicable 
Analysis 3.4. Comparison $3: 0.75 \mathrm{mg} / \mathrm{kg} /$ week 8 weeks versus highstandard $0.5 \mathrm{mg} / \mathrm{kg} /$ day 14 days, Outcome 4: Other adverse events

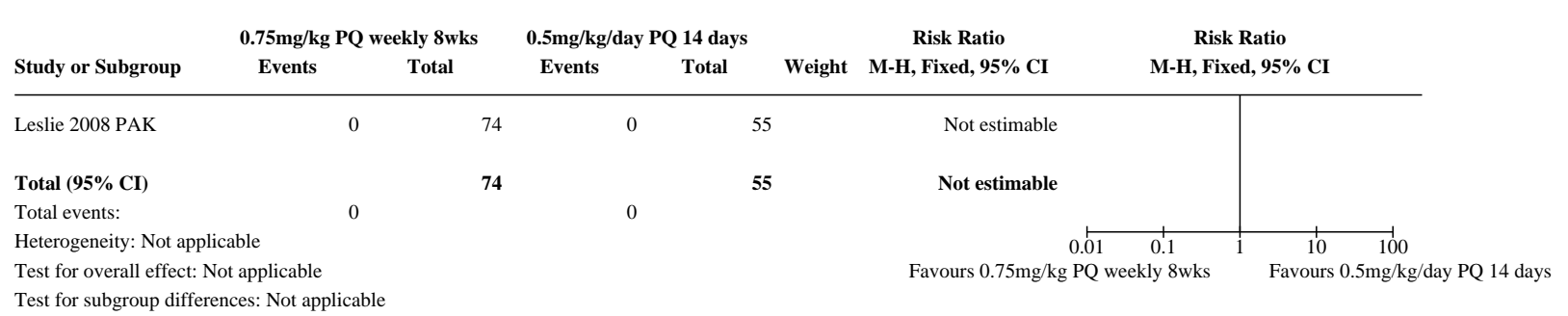

\section{Comparison $4.1 .0 \mathrm{mg} / \mathrm{kg} /$ day primaquine 7 days versus high-standard $0.5 \mathrm{mg} / \mathrm{kg} /$ day 14 days}

\begin{tabular}{|c|c|c|c|c|}
\hline Outcome or subgroup title & $\begin{array}{l}\text { No. of } \\
\text { studies }\end{array}$ & $\begin{array}{l}\text { No. of } \\
\text { partici- } \\
\text { pants }\end{array}$ & Statistical method & Effect size \\
\hline $\begin{array}{l}\text { 4.1 Recurrence by } 12 \text { months' } \\
\text { follow-up }\end{array}$ & 2 & 2526 & Risk Ratio (M-H, Fixed, 95\% Cl) & $1.03[0.82,1.30]$ \\
\hline $\begin{array}{l}4.1 .1 \text { Chloroquine blood-stage } \\
\text { treatment }\end{array}$ & 2 & 1404 & Risk Ratio (M-H, Fixed, 95\% Cl) & $0.91[0.67,1.22]$ \\
\hline $\begin{array}{l}\text { 4.1.2 DHA-PPQ blood-stage } \\
\text { treatment }\end{array}$ & 2 & 1122 & Risk Ratio (M-H, Fixed, 95\% Cl) & $1.24[0.87,1.77]$ \\
\hline $\begin{array}{l}4.2 \text { Recurrence by } 12 \text { months' } \\
\text { follow-up subgrouped by geo- } \\
\text { graphical region }\end{array}$ & 2 & 2526 & Risk Ratio (M-H, Fixed, 95\% Cl) & $1.03[0.82,1.29]$ \\
\hline 4.2.1 Afghanistan & 1 & 348 & Risk Ratio (M-H, Fixed, 95\% Cl) & $0.75[0.44,1.28]$ \\
\hline 4.2.2 Ethiopia & 1 & 466 & Risk Ratio (M-H, Fixed, 95\% Cl) & $1.30[0.74,2.30]$ \\
\hline 4.2.3 Indonesia & 1 & 797 & Risk Ratio (M-H, Fixed, 95\% Cl) & $1.32[0.86,2.03]$ \\
\hline 4.2.4 Thailand & 1 & 654 & Risk Ratio (M-H, Fixed, 95\% Cl) & $0.86[0.57,1.30]$ \\
\hline 4.2.5 Vietnam & 1 & 261 & Risk Ratio (M-H, Fixed, 95\% Cl) & $1.04[0.43,2.53]$ \\
\hline $\begin{array}{l}4.3 \text { Recurrence by } 6 \text { months' } \\
\text { follow-up }\end{array}$ & 1 & 474 & Risk Ratio (M-H, Fixed, 95\% Cl) & $1.10[0.61,1.97]$ \\
\hline $\begin{array}{l}\text { 4.3.1 Chloroquine blood-stage } \\
\text { treatment }\end{array}$ & 1 & 256 & Risk Ratio (M-H, Fixed, 95\% Cl) & $0.88[0.42,1.86]$ \\
\hline $\begin{array}{l}\text { 4.3.2 DHA-PPQ blood-stage } \\
\text { treatment }\end{array}$ & 1 & 218 & Risk Ratio (M-H, Fixed, 95\% Cl) & $1.55[0.60,4.05]$ \\
\hline $\begin{array}{l}4.4 \text { Recurrence by } 3 \text { months' } \\
\text { follow-up }\end{array}$ & 1 & & Risk Ratio (M-H, Fixed, 95\% Cl) & Totals not selected \\
\hline $\begin{array}{l}\text { 4.4.1 Chloroquine blood-stage } \\
\text { treatment }\end{array}$ & 1 & & Risk Ratio (M-H, Fixed, 95\% Cl) & Totals not selected \\
\hline
\end{tabular}




\begin{tabular}{|c|c|c|c|c|}
\hline Outcome or subgroup title & $\begin{array}{l}\text { No. of } \\
\text { studies }\end{array}$ & $\begin{array}{l}\text { No. of } \\
\text { partici- } \\
\text { pants }\end{array}$ & Statistical method & Effect size \\
\hline $\begin{array}{l}\text { 4.4.2 DHA-PPQ blood-stage } \\
\text { treatment }\end{array}$ & 1 & & Risk Ratio (M-H, Fixed, 95\% Cl) & Totals not selected \\
\hline 4.5 P vivax parasitaemia & 1 & & Risk Ratio (M-H, Fixed, 95\% Cl) & Totals not selected \\
\hline 4.5.1 Day 28 & 1 & & Risk Ratio (M-H, Fixed, 95\% Cl) & Totals not selected \\
\hline 4.5.2 Day 42 & 1 & & Risk Ratio (M-H, Fixed, 95\% Cl) & Totals not selected \\
\hline 4.6 Serious adverse events & 1 & & Risk Ratio (M-H, Fixed, 95\% Cl) & Subtotals only \\
\hline 4.6.1 Up to 42 days follow-up & 1 & 1872 & Risk Ratio (M-H, Fixed, 95\% Cl) & $12.03[1.57,92.30]$ \\
\hline 4.6.2 Up to 1 year follow-up & 1 & 1872 & Risk Ratio (M-H, Fixed, 95\% Cl) & $3.61[1.35,9.68]$ \\
\hline $\begin{array}{l}4.7 \text { Adverse events that result- } \\
\text { ed in discontinuation of treat- } \\
\text { ment }\end{array}$ & 2 & 2526 & Risk Ratio (M-H, Fixed, 95\% Cl) & $2.50[0.49,12.87]$ \\
\hline 4.8 Other adverse events & 2 & & Other data & No numeric data \\
\hline 4.8.1 Up to day 14 & 1 & & Other data & No numeric data \\
\hline $\begin{array}{l}\text { 4.8.2 Chloroquine group, up to } \\
\text { day } 42\end{array}$ & 1 & & Other data & No numeric data \\
\hline $\begin{array}{l}\text { 4.8.3 DHA-PPQ group, up to } \\
\text { day } 42\end{array}$ & 1 & & Other data & No numeric data \\
\hline 4.9 Anaemia & 2 & 2440 & Risk Ratio (M-H, Fixed, 95\% Cl) & $0.93[0.62,1.41]$ \\
\hline 4.9.1 Up to 3 days & 1 & 1786 & Risk Ratio (M-H, Fixed, 95\% Cl) & $1.00[0.38,2.66]$ \\
\hline 4.9.2 Up to 42 days follow-up & 1 & 654 & Risk Ratio (M-H, Fixed, 95\% Cl) & $0.91[0.58,1.44]$ \\
\hline
\end{tabular}


Analysis 4.1. Comparison 4: $1.0 \mathrm{mg} / \mathrm{kg} /$ day primaquine 7 days versus highstandard $0.5 \mathrm{mg} / \mathrm{kg} /$ day 14 days, Outcome 1: Recurrence by 12 months' follow-up

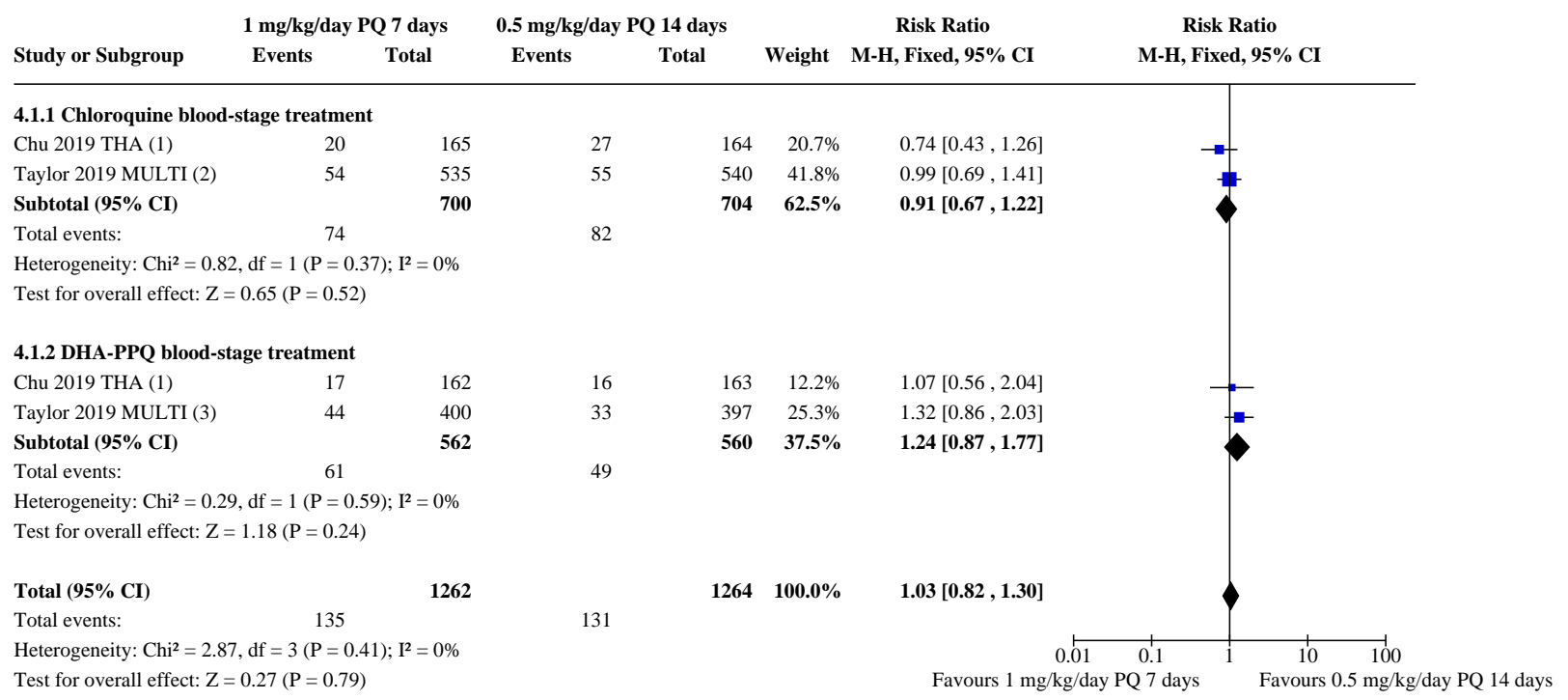

Test for subgroup differences: $\mathrm{Chi}^{2}=1.75, \mathrm{df}=1(\mathrm{P}=0.19), \mathrm{I}^{2}=43.0 \%$

\section{Footnotes}

(1) first $P$. vivax infection within 1 year

(2) first $P$. vivax recurrence, Afghanistan, Ethiopia, and Vietnam cohorts

(3) first $P$. vivax recurrence, Indonesia cohort 
Analysis 4.2. Comparison 4: $1.0 \mathrm{mg} / \mathrm{kg} /$ day primaquine 7 days versus high-standard $0.5 \mathrm{mg} / \mathrm{kg} /$ day 14 days, Outcome 2: Recurrence by 12 months' follow-up subgrouped by geographical region

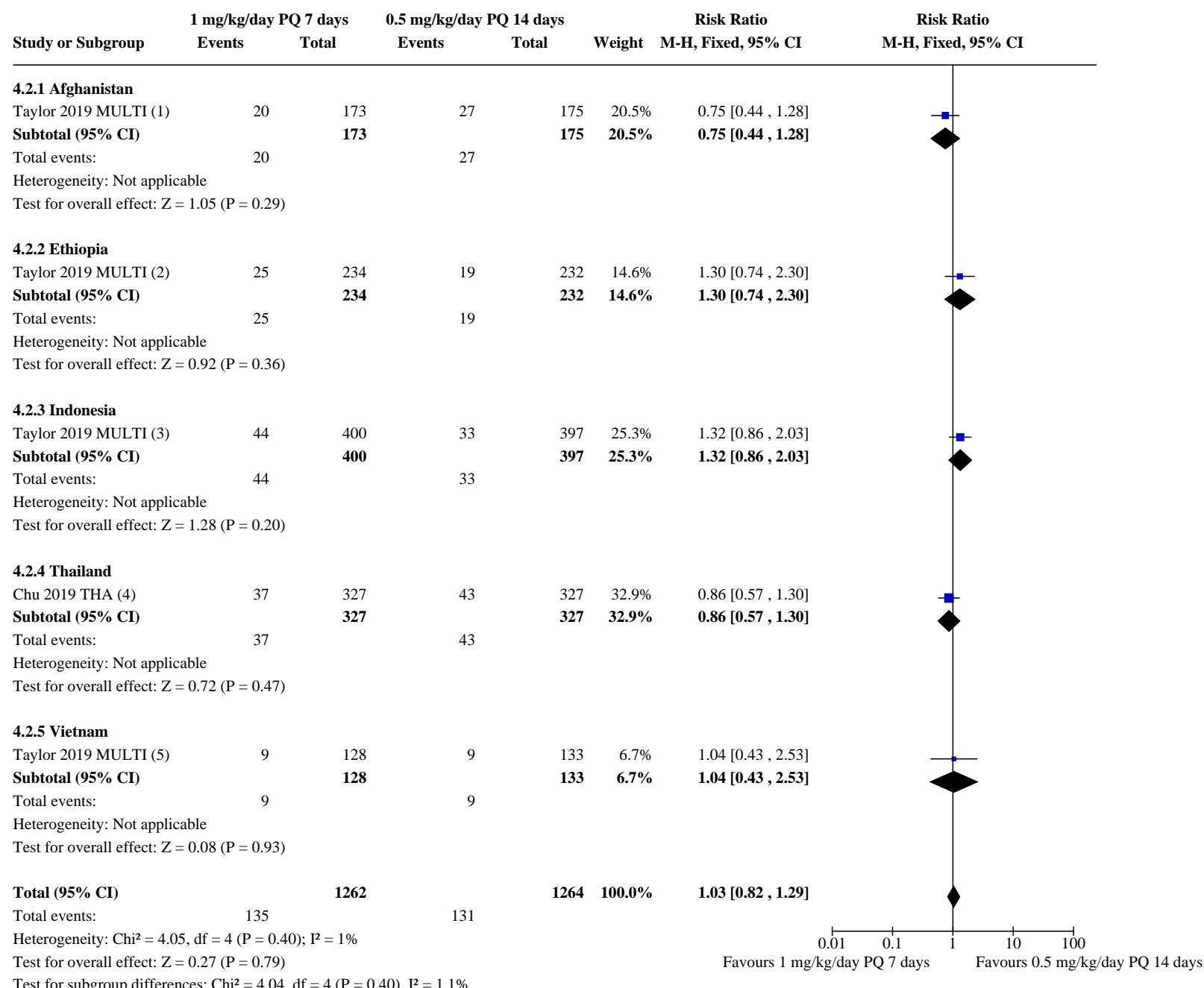

(1) first recurrent $P$. vivax parasitaemia, Afghanistan

(2) first recurrent $P$. vivax parasitaemia, Ethiopia

(3) first recurrent $P$. vivax parasitaemia, Indonesia

(4) first $P$. vivax infection within 1 year

(5) first recurrent $P$. vivax parasitaemia, Vietnam 
Analysis 4.3. Comparison 4: $1.0 \mathrm{mg} / \mathrm{kg} /$ day primaquine 7 days versus highstandard $0.5 \mathrm{mg} / \mathrm{kg} /$ day 14 days, Outcome 3: Recurrence by 6 months' follow-up

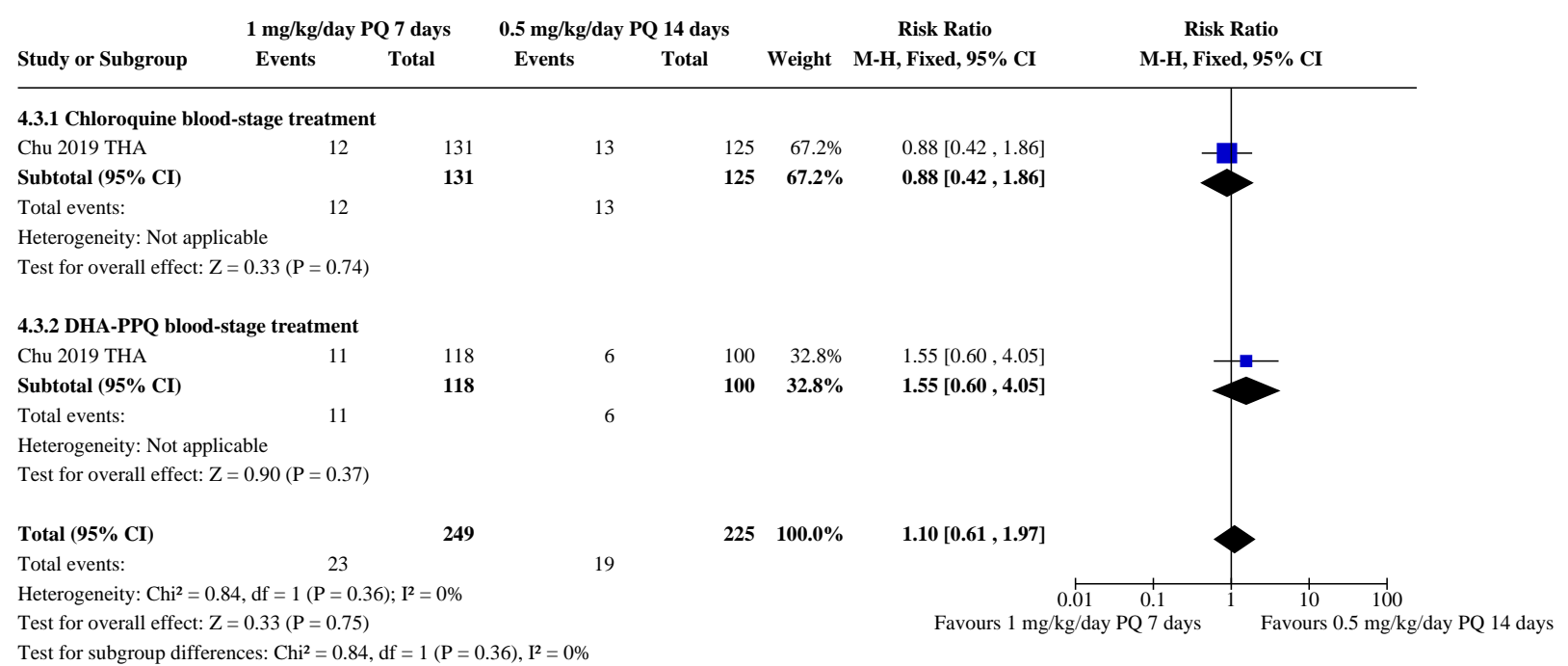

Analysis 4.4. Comparison $4: 1.0 \mathrm{mg} / \mathrm{kg} /$ day primaquine 7 days versus highstandard $0.5 \mathrm{mg} / \mathrm{kg} /$ day 14 days, Outcome 4: Recurrence by 3 months' follow-up

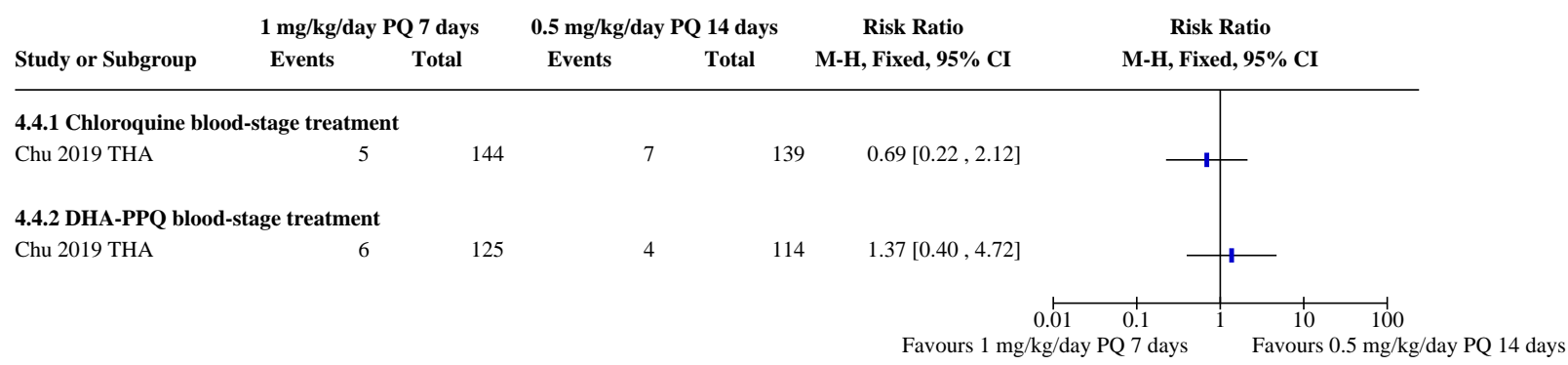

Analysis 4.5. Comparison $4: 1.0 \mathrm{mg} / \mathrm{kg} /$ day primaquine 7 days versus high-standard $0.5 \mathrm{mg} / \mathrm{kg} /$ day 14 days, Outcome 5: $P$ vivax parasitaemia

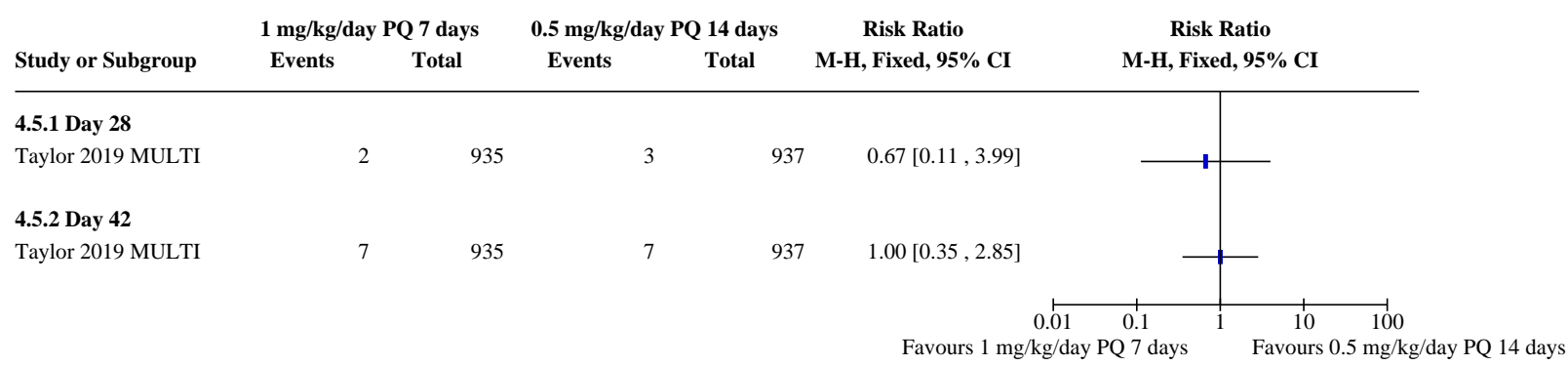


Analysis 4.6. Comparison $4: 1.0 \mathrm{mg} / \mathrm{kg} /$ day primaquine 7 days versus highstandard $0.5 \mathrm{mg} / \mathrm{kg} /$ day 14 days, Outcome 6: Serious adverse events

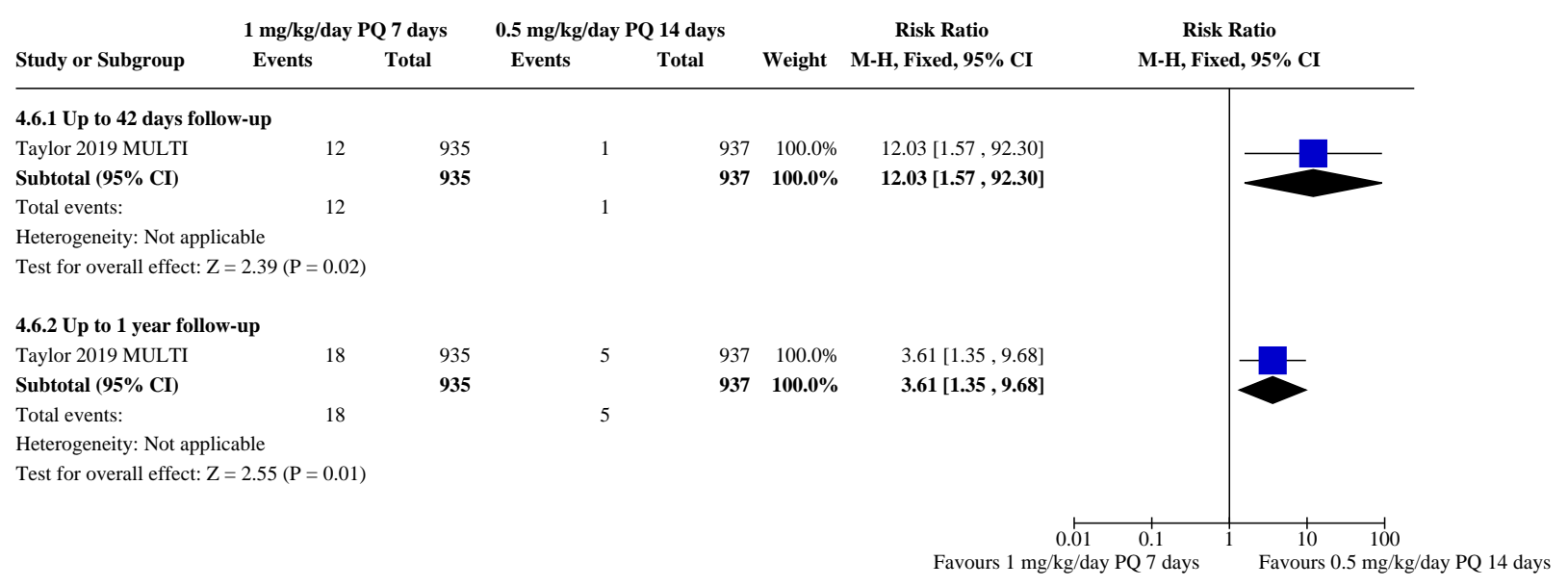

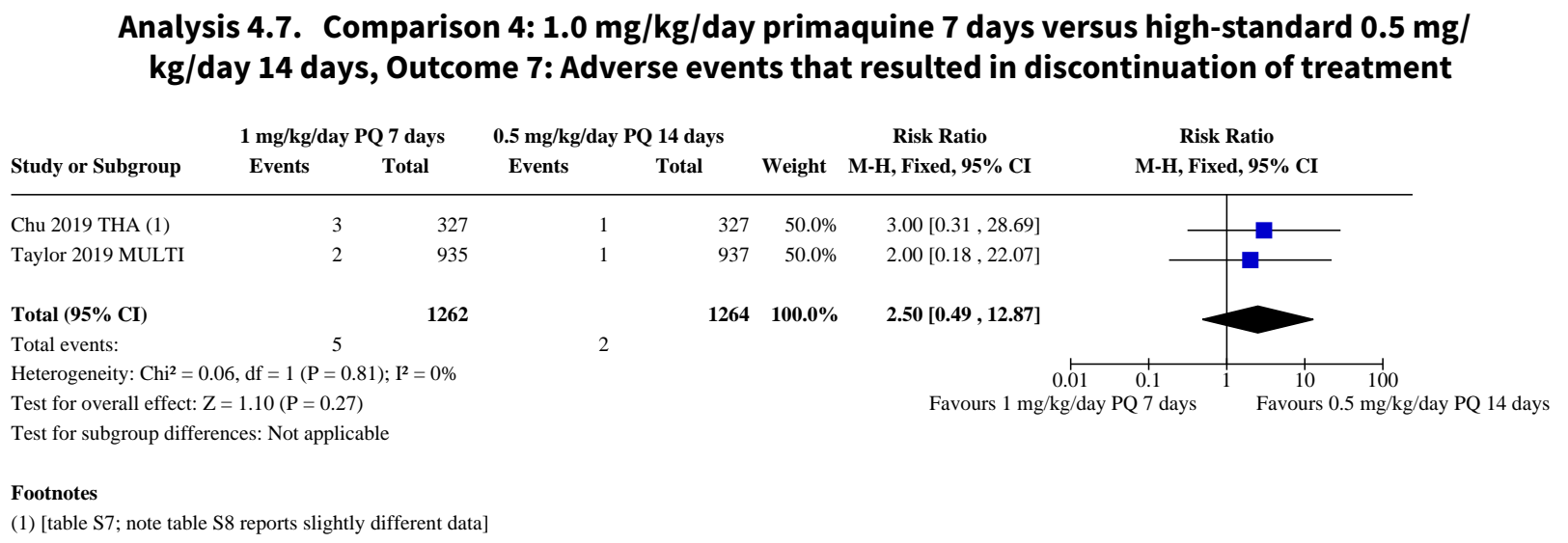

Analysis 4.8. Comparison $4: 1.0 \mathrm{mg} / \mathrm{kg} / \mathrm{day}$ primaquine 7 days versus high-standard $0.5 \mathrm{mg} / \mathrm{kg} /$ day 14 days, Outcome 8: Other adverse events

\begin{tabular}{lll}
\hline Other adverse events & & \\
\hline Study & $\mathbf{1 . 0} \mathbf{~ m g} / \mathbf{k g} /$ day for $\mathbf{7}$ days & High-standard $\mathbf{0 . 5} \mathbf{~ m g} / \mathbf{k g} / \mathbf{d a y}$ for $\mathbf{1 4}$ days \\
\hline Up to day $\mathbf{1 4}$ & & \\
\hline Taylor 2019 MULTI & 1819 events in 935 participants & \\
\hline Chloroquine group, up to day $\mathbf{4 2}$ & & \\
\hline Chu 2019 THA & 97 events in 165 participants & \\
\hline DHA-PPQ group, up to day $\mathbf{4 2}$ & & \\
\hline Chu 2019 THA & 72 participants \\
\hline
\end{tabular}


Analysis 4.9. Comparison $4: 1.0 \mathrm{mg} / \mathrm{kg} /$ day primaquine 7 days versus high-standard $0.5 \mathrm{mg} / \mathrm{kg} /$ day 14 days, Outcome 9: Anaemia

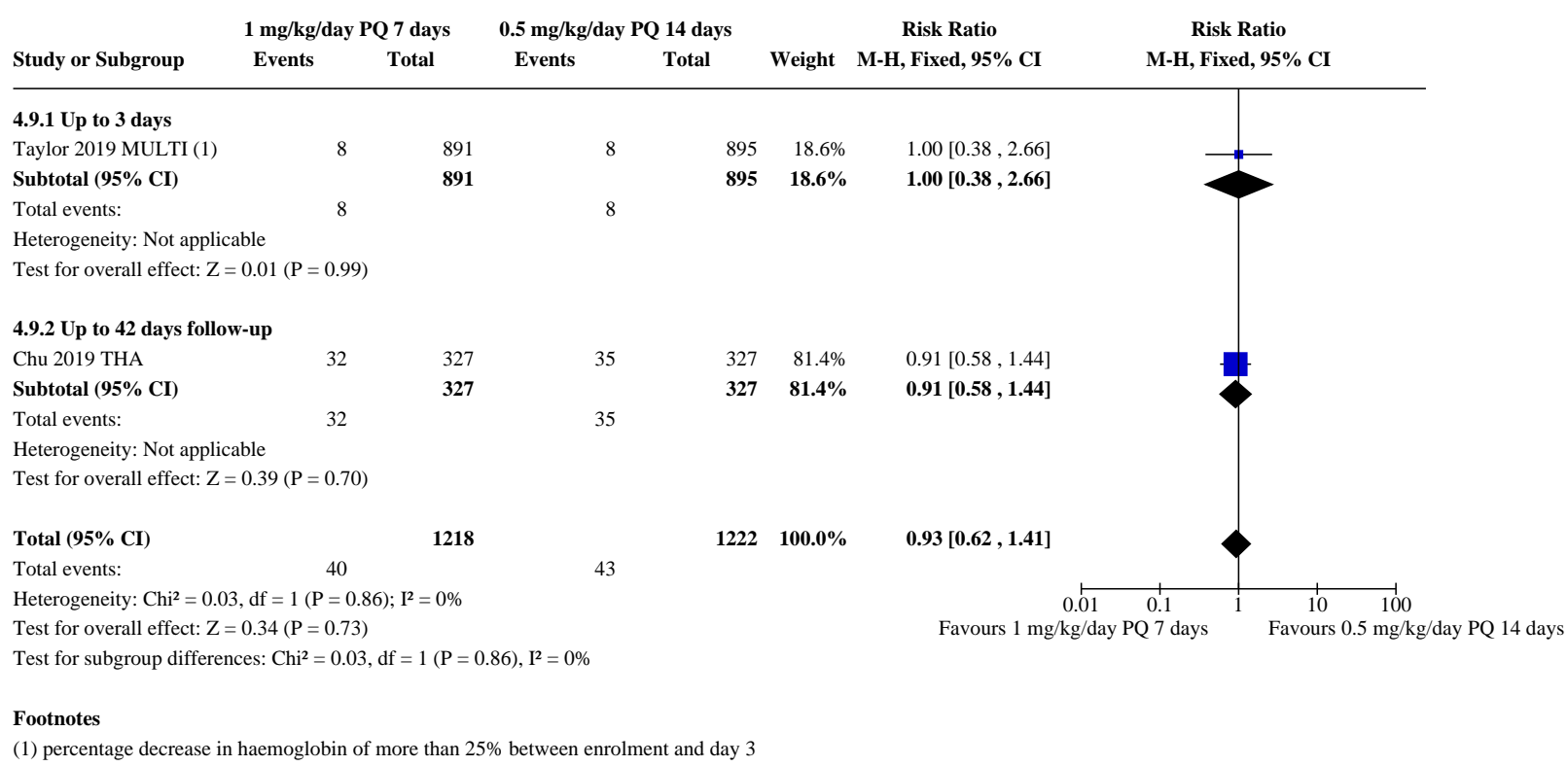

\section{Comparison $5.0 .375 \mathrm{mg} / \mathrm{kg} /$ day primaquine for 14 days versus standard 14-day regimen}

\begin{tabular}{llllll}
\hline Outcome or subgroup title & $\begin{array}{l}\text { No. of } \\
\text { studies }\end{array}$ & $\begin{array}{l}\text { No. of } \\
\text { partici- } \\
\text { pants }\end{array}$ & Statistical method & Effect size \\
\hline 5.1 Recurrence by 6 months' follow-up & 1 & & Risk Ratio (M-H, Fixed, 95\% Cl) & Subtotals only \\
\hline 5.1 .16 months' follow-up & 1 & 73 & Risk Ratio (M-H, Fixed, 95\% Cl) & $0.17[0.01,3.34]$ \\
\hline 5.1 .212 months' follow-up & 1 & 49 & Risk Ratio (M-H, Fixed, 95\% Cl) & Not estimable \\
\hline 5.1 .318 months' follow-up & 1 & 38 & Risk Ratio (M-H, Fixed, 95\% Cl) & Not estimable \\
\hline
\end{tabular}




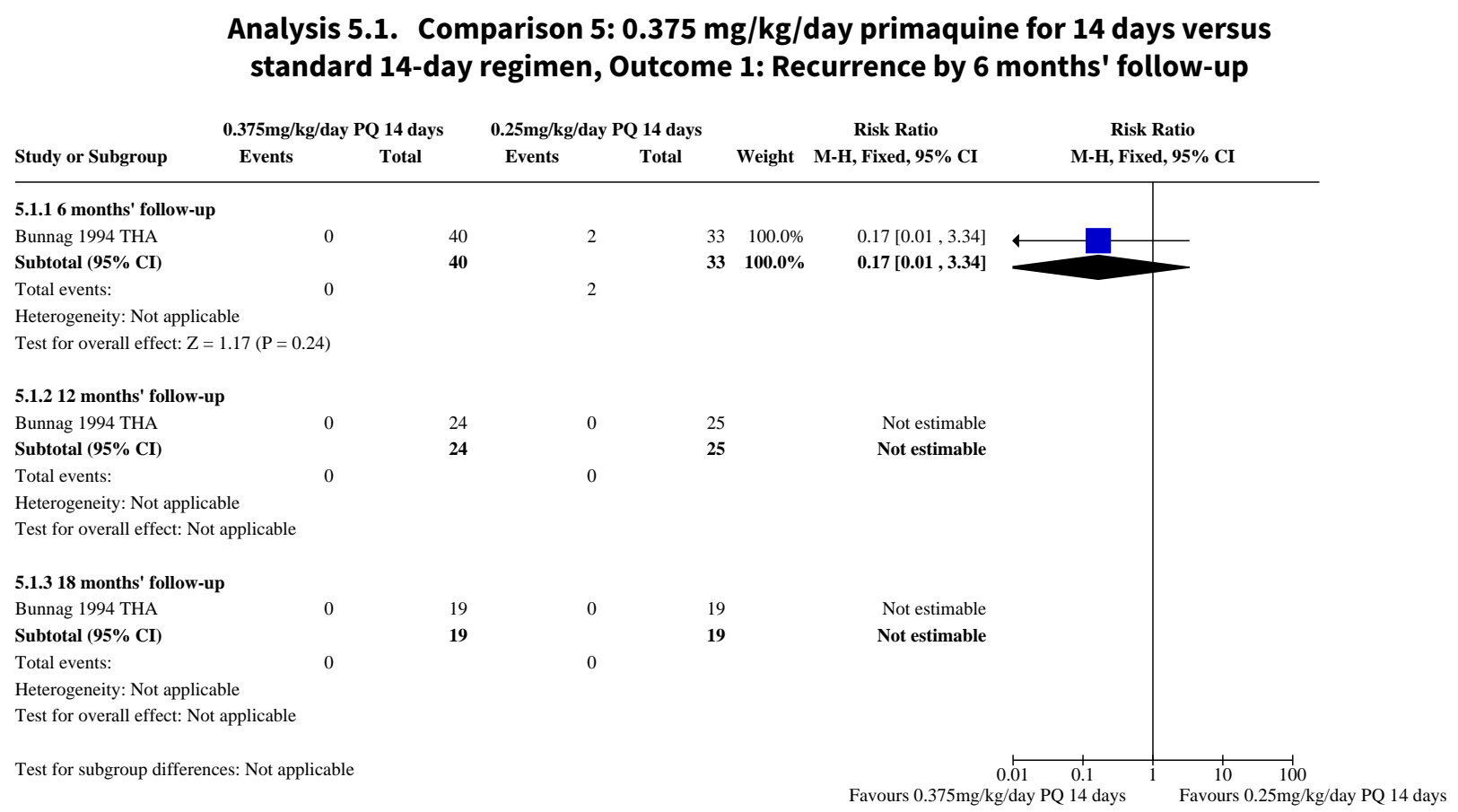

Comparison 6. $1.17 \mathrm{mg} / \mathrm{kg} /$ day primaquine for 3 days versus standard 14-day regimen

\begin{tabular}{lllll}
\hline Outcome or subgroup title & $\begin{array}{l}\text { No. of } \\
\text { studies }\end{array}$ & $\begin{array}{l}\text { No. of partici- } \\
\text { pants }\end{array}$ & Statistical method & Effect size \\
\hline 6.1 Recurrence by 4 months' follow-up & 1 & 129 & Risk Ratio (M-H, Fixed, 95\% Cl) & $3.88[2.11,7.11]$ \\
\hline
\end{tabular}

Analysis 6.1. Comparison $6: 1.17 \mathrm{mg} / \mathrm{kg} /$ day primaquine for 3 days versus standard 14-day regimen, Outcome 1: Recurrence by 4 months' follow-up

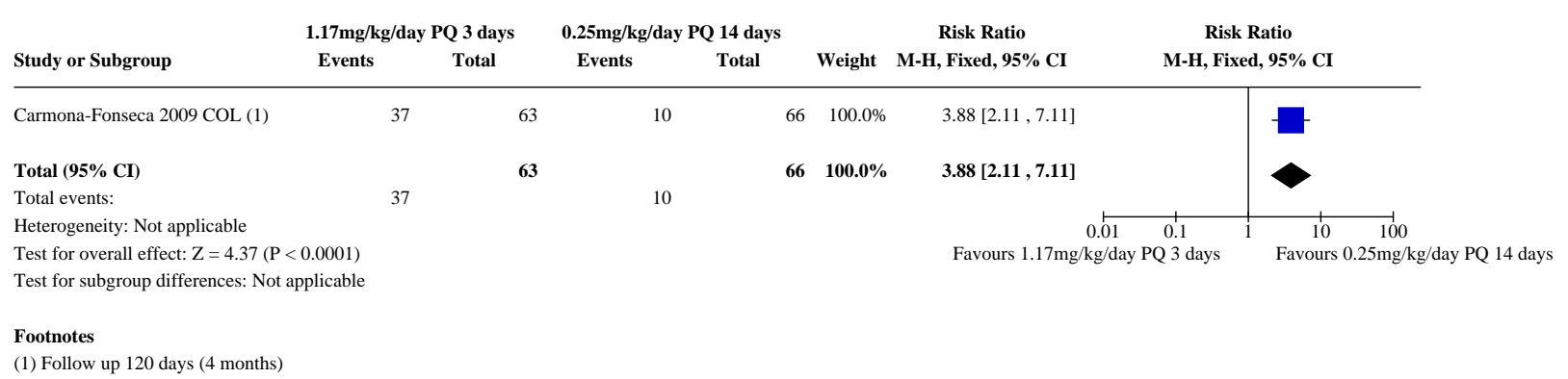

\section{ADDITIONAL TABLES}

Table 1. Data extraction: grouping of comparisons to address the review's objectives

Objective Intervention Control




\section{Table 1. Data extraction: grouping of comparisons to address the review's objectives (Continued)}

Are higher doses $(0.5$ $\mathrm{mg} / \mathrm{kg} /$ day or $30 \mathrm{mg} /$ day primaquine for 14 days) more effective in all areas, or only in areas where they are standard treatment (East Asia and Oceania)?

Are shorter, higher-dose regimens of primaquine over 7 days as effective as treatment over 14 days (is the total dose rather than the length of treatment the important factor)?

Are weekly dosing regimens $(0.75 \mathrm{mg} / \mathrm{kg} /$ week or $45 \mathrm{mg} /$ week for 8 weeks) as effective?
Blood-stage antimalarial drug with primaquine $0.5 \mathrm{mg} / \mathrm{kg} /$ day (adult dose 30 $\mathrm{mg}$ ) for 14 days (total dose $420 \mathrm{mg}$ ).

Both intervention and control groups must have received the same treatment for the blood-borne stage of infection, that is, either CQ or ACT.
Blood-stage antimalarial drug with standard 14-day course primaquine $(0.25 \mathrm{mg} / \mathrm{kg} / \mathrm{day}$, adult dose $15 \mathrm{mg}$, total dose $210 \mathrm{mg}$ )

Both intervention and control groups must have received the same treatment for the blood-borne stage of infection, that is, either CQ or ACT.
Blood-stage antimalarial drug with primaquine $0.5 \mathrm{mg} / \mathrm{kg} /$ day (adult dose 30 $\mathrm{mg}$ ) for 7 days (total dose $210 \mathrm{mg}$ ) or 1 $\mathrm{mg} / \mathrm{kg} /$ day (adult dose $60 \mathrm{mg}$ ) for 7 days (total dose $420 \mathrm{mg}$ ).

Both intervention and control groups must have received the same treatment for the blood-borne stage of infection, that is, either CQ or ACT.
Blood-stage antimalarial drug with standard 14-day course primaquine $(0.25 \mathrm{mg} / \mathrm{kg} /$ day, adult dose $15 \mathrm{mg}$, total dose $210 \mathrm{mg}$ ) or high-standard 14-day course primaquine $(0.5 \mathrm{mg} /$ $\mathrm{kg} /$ day, adult dose $30 \mathrm{mg}$, total dose $420 \mathrm{mg}$ ).

Both intervention and control groups must have received the same treatment for the blood-borne stage of infection, that is, either CQ or ACT.
Blood-stage antimalarial drug with primaquine $0.75 / \mathrm{kg}(45 \mathrm{mg})$ per week for 8 weeks (total dose $360 \mathrm{mg}$ )
Blood-stage antimalarial drug with standard 14-day course primaquine $(0.25 \mathrm{mg} / \mathrm{kg} /$ day, adult dose $15 \mathrm{mg}$, total dose $210 \mathrm{mg}$ ) or high-standard 14-day course primaquine $(0.5 \mathrm{mg} /$ $\mathrm{kg} /$ day, adult dose $30 \mathrm{mg}$, total dose $420 \mathrm{mg}$ ).

Both intervention and control groups must have received the same treatment for the blood-borne stage of infection, that is, either CQ or ACT.

Abbreviations: $\mathrm{ACT}=$ artemisinin-based combination therapy; $\mathrm{CQ}=$ chloroquine .

\section{APPENDICES}

Appendix 1. Detailed search strategies

\section{PubMed MEDLINE}

\begin{tabular}{ll}
\hline 1 & primaquine [Title/Abstract] \\
\hline 2 & "Primaquine"[Mesh] \\
\hline 3 & 1 or 2 \\
\hline 4 & "plasmodium vivax" [Title/Abstract] \\
\hline 5 & "Plasmodium vivax"[Mesh] \\
\hline 6 & "vivax malaria " [Title/Abstract] \\
\hline 7 & "Malaria, Vivax"[Mesh] \\
\hline 8 & 4 or 5 or 6 \\
\hline 9 & 3 and 8 \\
\hline
\end{tabular}

Primaquine alternative dosing schedules for preventing malaria relapse in people with Plasmodium vivax (Review) 


\begin{tabular}{ll}
\hline 13 & "drug therapy" [Subheading] \\
\hline 14 & 10 or 11 or 12 or 13 \\
\hline 15 & 9 and 14 \\
\hline
\end{tabular}

\section{Cochrane Library}

Issue 92019

ID Search

\#1 primaquine: ti,ab,kw: (Word variations have been searched)

\#2 MeSH descriptor: [Primaquine] explode all trees

\#3 \#1 or \#2

\#4 "plasmodium vivax": ti, ab,kw (Word variations have been searched)

\#5 MeSH descriptor: [Malaria, Vivax] explode all trees

\#6 MeSH descriptor: [Plasmodium vivax ] explode all trees

\#7 \#4 or \#5 or \#6

\#8 \#3 and \#7

\section{Embase}

1947-Present, updated daily

1 "primaquine".mp.

2 primaquine/

31 or 2

4 plasmodium vivax.mp. or Plasmodium vivax/

5 malaria vivax.mp. or Plasmodium vivax malaria/

64 or 5 or 6

7 controlled clinical trial.mp. or Controlled Clinical Trial/

8 randomized controlled trial.mp. or Randomized Controlled Trial/

9 (randomized or placebo or double-blind* or single-blind*).mp.

10 randomization/

11 crossover procedure/

127 or 8 or 9 or 10 or 11 
133 and 6 and 12

\section{LILACS}

Search on: primaquine [Words] and malaria vivax or plasmodium vivax [Words]

\section{ClinicalTrials.gov and WHO ICTRP}

primaquine and vivax

\section{Appendix 2. Safety additional data}

High-standard 14-day regimen versus standard 14-day regimen

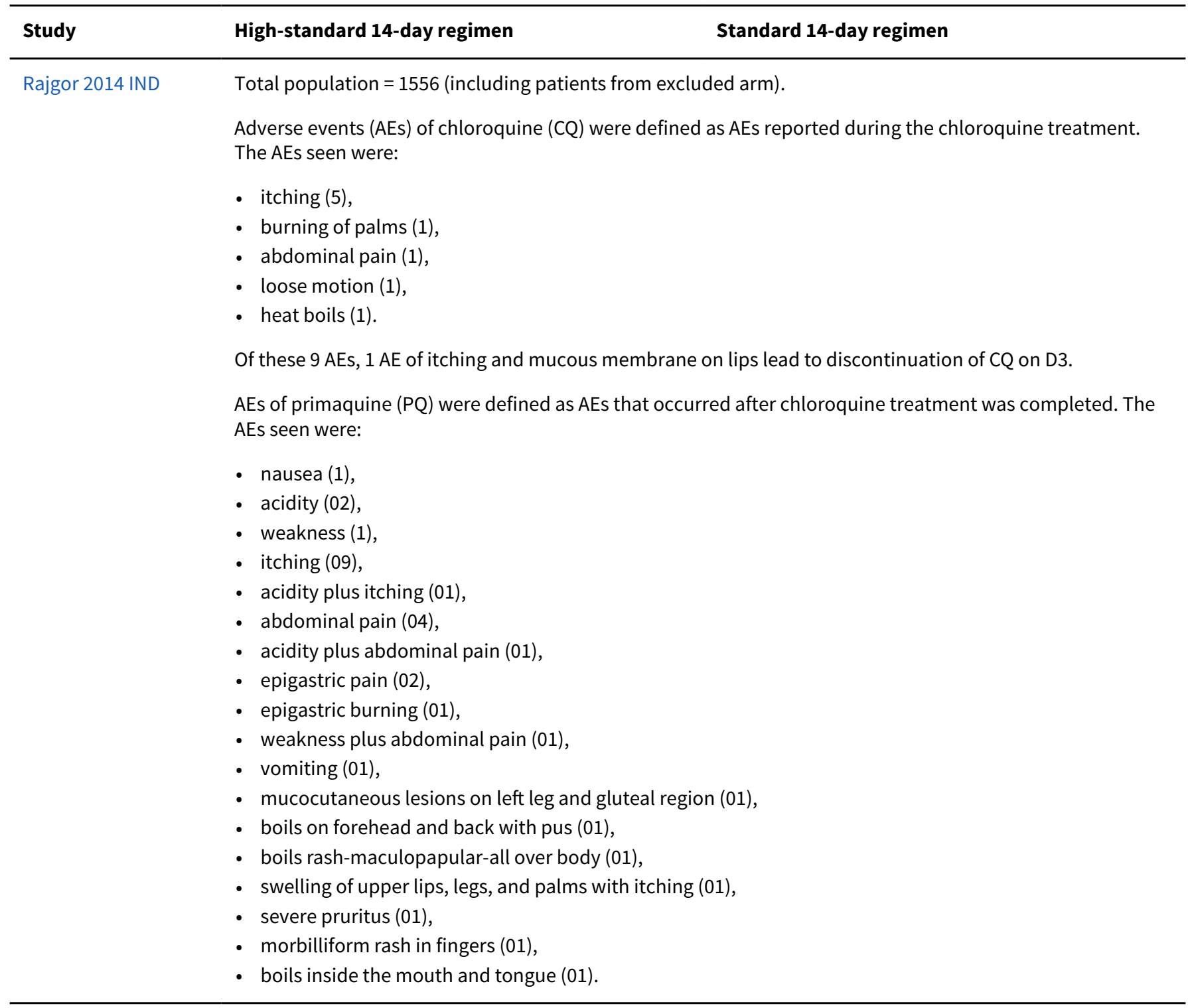

$20.5 \mathrm{mg} / \mathrm{kg} /$ day for 7 days versus standard 14-day regimen

Study $\quad 0.5 \mathrm{mg} / \mathrm{kg} /$ day for 7 days Standard 14-day regimen

Primaquine alternative dosing schedules for preventing malaria relapse in people with Plasmodium vivax (Review) 
(Continued)

Abdon 2001 BRA Total population = 23 patients (including participants from excluded arm); 19.2\% experienced AEs, these included:

- diarrhoea (5.8\%)

- nausea $(5 \%)$

- itching (5\%)

- vomiting $(1.7 \%)$

- epigastric pain (1.7\%)

- dizziness $(0.8 \%)$

- tinnitus $(0.8 \%)$

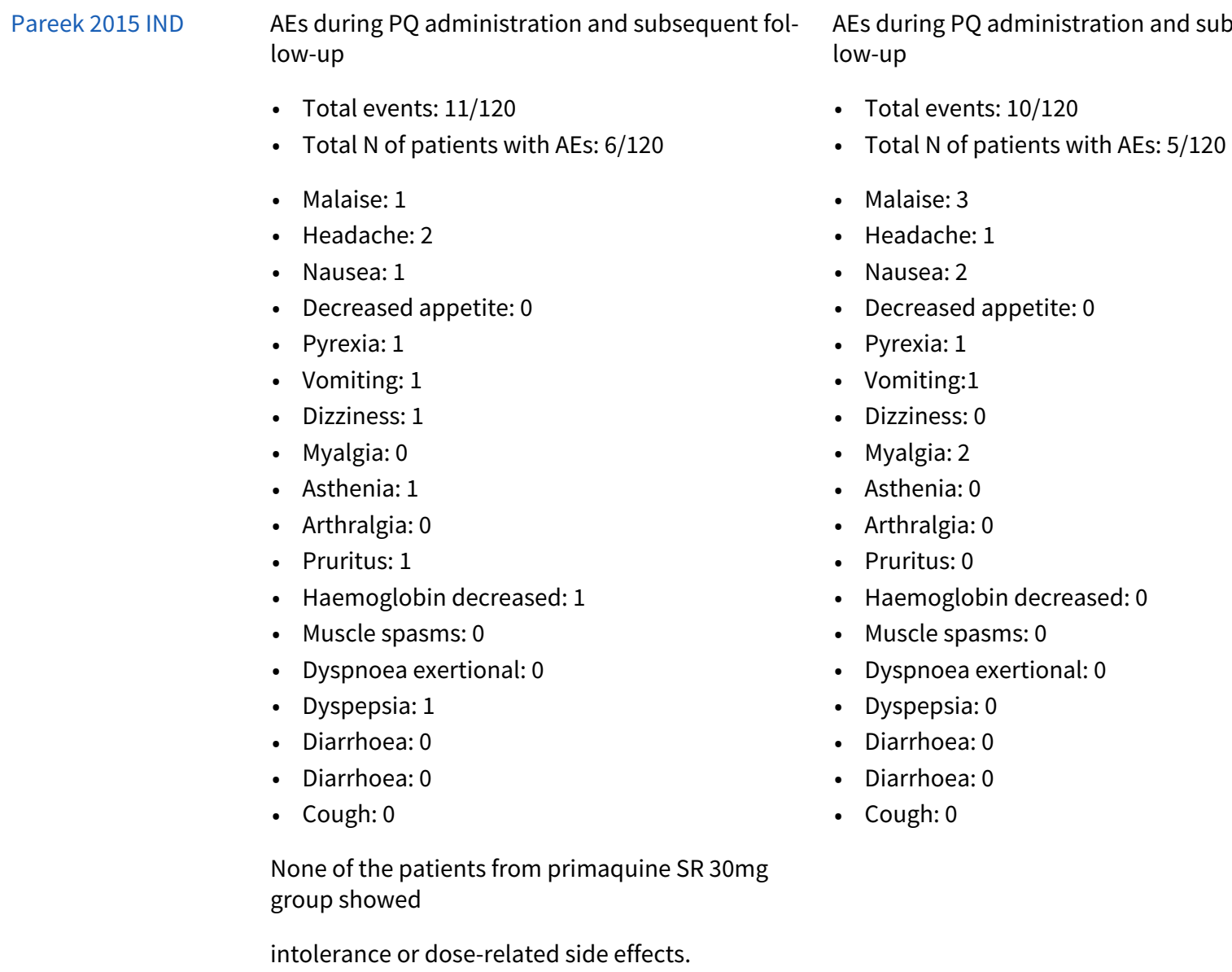

Rajgor 2014 IND Total population = 1556 (including patients from excluded arm).

AEs of chloroquine were defined as AEs reported during the chloroquine treatment. The AEs seen were:

- itching (5),

- burning of palms (1),

- abdominal pain (1),

- loose motion (1),

- heat boils (1).

Of these $9 \mathrm{AEs}, 1 \mathrm{AE}$ of itching and mucous membrane on lips lead to discontinuation of CQ on D3.

AEs of primaquine were defined as AEs that occurred after chloroquine treatment was completed. The AEs seen were:

- $\operatorname{nausea~(1),~}$ 
(Continued)

- acidity (02),

- weakness (1),

- itching (09),

- acidity plus itching (01),

- abdominal pain (04),

- acidity plus abdominal pain (01),

- epigastric pain (02),

- epigastric burning (01),

- weakness plus abdominal pain (01),

- vomiting (01),

- mucocutaneous lesions on left leg and gluteal region (01),

- boils on forehead and back with pus (01),

- boils rash-maculopapular-all over body (01),

- swelling of upper lips, legs, and palms with itching (01),

- severe pruritus (01),

- morbilliform rash in fingers (01),

- boils inside the mouth and tongue (01)

$1 \mathrm{mg} / \mathrm{kg} /$ day for 7 days versus high-standard 14-day regimen

\begin{tabular}{|c|c|c|}
\hline Study & $1 \mathrm{mg} / \mathrm{kg} /$ day for 7 days & high-standard 14-day regimen \\
\hline \multirow[t]{8}{*}{ Chu 2019 THA } & $\begin{array}{l}\text { AEs leading to discontinuation of treatment by blood-stage } \\
\text { antimalarial treatment: } \\
\text { - chloroquine group: } 1 / 165 \\
\text { - DHA-PPQ group: } 2 / 162\end{array}$ & $\begin{array}{l}\text { AEs leading to discontinuation of treatment } \\
\text { by blood-stage antimalarial treatment: } \\
\text { - chloroquine group: } 0 / 164 \\
\text { - DHA-PPQ: } 1 / 163\end{array}$ \\
\hline & $\begin{array}{l}\text { Anaemia or change in haemoglobin status } \\
\text { - chloroquine group: } 12 / 165 \\
\text { - DHA-PPQ group: } 20 / 162\end{array}$ & $\begin{array}{l}\text { Anaemia or change in haemoglobin status } \\
\text { - chloroquine group: } 17 / 165 \\
\text { - DHA-PPQ group: } 18 / 162\end{array}$ \\
\hline & Other adverse events & Other adverse events \\
\hline & $\begin{array}{l}\text { - Abdominal pain } \\
* \text { chloroquine group: } 44 / 165 \\
* \text { DHA-PPQ group: } 25 / 162\end{array}$ & $\begin{array}{l}\text { - Abdominal pain } \\
* \text { chloroquine group: } 35 / 164 \\
* \text { DHA-PPQ group: } 13 / 163\end{array}$ \\
\hline & $\begin{array}{l}\text { - Nausea or vomiting } \\
* \text { chloroquine group: } 12 / 165 \\
* \text { DHA-PPQ group: } 5 / 162\end{array}$ & $\begin{array}{l}\text { Nausea or vomiting } \\
* \text { chloroquine group: } 10 / 164 \\
* \text { DHA-PPQ group: } 9 / 163\end{array}$ \\
\hline & $\begin{array}{l}\text { Dizziness } \\
* \text { chloroquine group: } 15 / 165 \\
* \text { DHA-PPQ group: } 18 / 162\end{array}$ & $\begin{array}{l}\text { Dizziness } \\
* \text { chloroquine group: } 22 / 164 \\
* \text { DHA-PPQ group: } 29 / 163\end{array}$ \\
\hline & $\begin{array}{l}\text { - Headache } \\
* \text { chloroquine group: } 15 / 165 \\
* \text { DHA-PPQ group: } 18 / 162\end{array}$ & $\begin{array}{l}\text { - Headache } \\
* \text { chloroquine group: } 15 / 164 \\
* \text { DHA-PPQ group: } 21 / 163\end{array}$ \\
\hline & $\begin{array}{l}\text { Fatigue } \\
* \text { chloroquine group: } 11 / 165 \\
* \text { DHA-PPQ group: } 6 / 162\end{array}$ & $\begin{array}{l}\text { Fatigue } \\
* \text { chloroquine group: } 9 / 164 \\
* \text { DHA-PPQ group: } 10 / 163\end{array}$ \\
\hline
\end{tabular}


- Primaquine-related, up to 42 days follow-up: 9/935

- Primaquine-unrelated, up to 42 days follow-up: $3 / 935$

- Primaquine-related, up to 1 year follow-up: 9/935

- Primaquine-unrelated, up to 1 year follow-up: 9/935

Related events include those that are possibly, probably or definitely related
- Primaquine-related, up to 42 days follow-up: 1/937

- Primaquine-unrelated, up to 42 days follow-up: 0/937

- Primaquine-related, up to 1 year follow-up: $1 / 937$

- Primaquine-unrelated, up to 1 year follow-up: 4/937

Related events include those that are possibly, probably or definitely related

\section{SAE details}

Up to 42 days

Up to 42 days

- Persistent vomiting - 2 days after treatment (possibly related)

- Acute haemolysis (Hb drop from 13.7 to $9.5 \mathrm{~g} / \mathrm{dL}$ ) - 3 days after treatment (definitely related)

- Haemolysis (Hb drop from 11.6 to $6.9 \mathrm{~g} / \mathrm{dL}$ ) - 3 days after treatment (possibly related)

- Epigastric pain - 4 days after treatment (possibly related)

- Persistent vomiting - 4 days after treatment (probably related)

- Acute haemolysis (Hb drop from 15.3 to $6.4 \mathrm{~g} / \mathrm{dL}$ ) - 5 days after treatment (definitely related)

- Diarrhoea - 7 days after treatment (definitely related)

- Fever, abdominal pain, dyspnoea - 9 days after treatment (possibly related)

- Symptomatic methaemoglobinaemia and bronchopneumonia - 10 days after treatment (definitely related)

- Severe malaria (Pfalciparum + P vivax) -2 days after treatment (not related)

- Abdominal pain, fever of unexplained origin - 6 days after treatment (not related)

- Persistent vomiting - 10 days after treatment (not related)

42 days to 1 year

- Severe $P$ falciparum malaria - 46 days after treatment (not related)

- Unilateral periorbital ecchymosis - 54 days after treatment (not related)

- Severe $P$ falciparum malaria - 57 days after treatment (not related)

- Sudden unexpected death due to myocardial infarction 151 days after treatment (not related)

- Acute appendicitis - 170 days after treatment

- Severe $P$ falciparum malaria - 221 days after treatment (not related)
- Haemolysis (Hb drop from 10.2 to $6.8 / \mathrm{dL}$ ) 3 days after treatment (probably related)

42 days to 1 year

- Acute exacerbation of bronchial asthma precipitated by pneumonia - 91 days after treatment (not related)

- Generalized peritonitis - 92 days after treatment (not related)

- Complicated puncture wound - 129 days after treatment (not related)

- Undifferentiated carcinoma in nasopharynx - 147 days after treatment (not related)
- Mean (SD) absolute decrease in haemoglobin at day 3, g/ $\mathrm{dL}=0.52(1.19)$

- Mean (SD) absolute decrease in haemoglobin at day $7, \mathrm{~g} /$ $\mathrm{dL}=0.01(1.23)$
- Mean (SD) absolute decrease in haemoglobin at day $3, \mathrm{~g} / \mathrm{dL}=0.62$ (1.09)

- Mean (SD) absolute decrease in haemoglobin at day $7, \mathrm{~g} / \mathrm{dL}=0.12$ (1.09) 
Symptoms elicited from daily questionnaires, 1-14 days after starting antimalarial treatment

- Headache: $480 / 935$

- Diarrhoea: 95/935

- Skin rash:22/935

- Poor appetite: 407/935

- Myalgia or arthralgia: 243/935

- Fever: 294/935

- Passing dark urine: $55 / 935$

- Dizziness: 166/935

- Shortness of breath: 33/935

- Itching: $24 / 935$
Symptoms elicited from daily questionnaires, 1-14 days after starting antimalarial treatment

- Headache: $465 / 937$

- Diarrhoea: 52/937

- Skin rash: 26/937

- Poor appetite: 374/937

- Myalgia or arthralgia: 236/937

- Fever: 319/937

- Passing dark urine: $48 / 937$

- Dizziness: $157 / 937$

- Shortness of breath: 29/937

- Itching: $26 / 937$

\section{Appendix 3. Primary outcomes additional analyses}

3a. Rate ratios and hazard ratios for the outcome 'Recurrence' at 12 months follow-up of the comparison ' $1.0 \mathrm{mg} / \mathrm{kg} / \mathrm{day}$ primaquine for 7 days versus high-standard 14-day regimen'

\begin{tabular}{|c|c|c|c|c|c|}
\hline Subgroup & Study & $\begin{array}{l}\text { Events/per- } \\
\text { son-yearsa }\end{array}$ & $\begin{array}{l}\text { Rate ratio }(95 \% \\
\mathrm{CI})\end{array}$ & $\begin{array}{l}\text { Pooled } \\
\text { rate ratio } \\
(95 \% \mathrm{Cl})^{b}\end{array}$ & $\mathrm{HR}(95 \% \mathrm{Cl}) \mathrm{C}$ \\
\hline \multirow[t]{3}{*}{$\begin{array}{l}\text { Blood-stage drug: } \\
\text { chloroquine }\end{array}$} & $\begin{array}{l}\text { Chu } 2019 \\
\text { THA }\end{array}$ & PQ7: 20/128 & $0.72(0.28$ to 1.90$)$ & \multirow{3}{*}{$\begin{array}{l}\text { Subtotal: } \\
0.99(0.70 \\
\text { to } 1.40)\end{array}$} & - \\
\hline & & PQ14: 26/125 & & & \\
\hline & $\begin{array}{l}\text { Taylor } 2019 \\
\text { MULTI }\end{array}$ & $\begin{array}{l}\text { PQ7: 54/286 } \\
\text { PQ14: 55/303 }\end{array}$ & 1.04 (0.71 to 1.51$)$ & & - \\
\hline \multirow[t]{3}{*}{$\begin{array}{l}\text { Blood-stage drug: } \\
\text { DHA-PPQ }\end{array}$} & $\begin{array}{l}\text { Chu } 2019 \\
\text { THA }\end{array}$ & & 1.14 (0.57 to 2.25$)$ & \multirow{3}{*}{$\begin{array}{l}\text { Subtotal: } \\
1.27(0.87 \\
\text { to } 1.85)\end{array}$} & - \\
\hline & & PQ14: 16/122 & & & \\
\hline & $\begin{array}{l}\text { Taylor } 2019 \\
\text { MULTI }\end{array}$ & $\begin{array}{l}\text { PQ7: } 44 / 311 \\
\text { PQ14: 33/312 }\end{array}$ & 1.34 (0.85 to 2.10$)$ & & - \\
\hline \multicolumn{4}{|c|}{ See Analysis 4.1 for risk ratio. } & $\begin{array}{l}\text { Total: } 1.11 \\
(0.86 \text { to } \\
1.44)\end{array}$ & $\begin{array}{l}\text { Total HR reported in Taylor } 2019 \\
\text { MULTI: } 1.17 \text { (0.88 to } 1.55)\end{array}$ \\
\hline $\begin{array}{l}\text { Geographical re- } \\
\text { gion: Afghanistan }\end{array}$ & $\begin{array}{l}\text { Taylor } 2019 \\
\text { MULTI }\end{array}$ & $\begin{array}{l}\text { PQ7: 20/74 } \\
\text { PQ14: } 27 / 78\end{array}$ & 0.78 (0.44 to 1.40$)$ & & $\begin{array}{l}\text { Jalalabad: } 0.74 \text { (0.30 to } 1.84) \\
\text { Laghman: } 0.90 \text { (0.44 to } 1.83 \text { ) }\end{array}$ \\
\hline $\begin{array}{l}\text { Geographical re- } \\
\text { gion: Ethiopia }\end{array}$ & $\begin{array}{l}\text { Taylor } 2019 \\
\text { MULTI }\end{array}$ & $\begin{array}{l}\text { PQ7: } 25 / 124 \\
\text { PQ14: 19/135 }\end{array}$ & 1.42 (0.78 to 2.58$)$ & & $\begin{array}{l}\text { Arba Minch: } 1.54 \text { (0.79 to } 2.98 \text { ) } \\
\text { Metahara: } 1.08 \text { (0.35 to } 3.34 \text { ) }\end{array}$ \\
\hline $\begin{array}{l}\text { Geographical re- } \\
\text { gion: Indonesia }\end{array}$ & $\begin{array}{l}\text { Taylor } 2019 \\
\text { MULTI }\end{array}$ & $\begin{array}{l}\text { PQ7: 44/311 } \\
\text { PQ14: 33/312 }\end{array}$ & 1.34 (0.85 to 2.10$)$ & & Hanura: 1.16 (0.71 to 1.90$)$ \\
\hline
\end{tabular}


(Continued)

Tanjung Leidong: 2.36 ( 0.83 to

6.69)

\begin{tabular}{|c|c|c|c|c|c|}
\hline $\begin{array}{l}\text { Geographical re- } \\
\text { gion: Thailand }\end{array}$ & $\begin{array}{l}\text { Chu } 2019 \\
\text { THA }\end{array}$ & $\begin{array}{l}\text { PQ7: } 37 / 242 \\
\text { PQ14:42/247 }\end{array}$ & 0.90 (0.58 to 1.40$)$ & & - \\
\hline $\begin{array}{l}\text { Geographical re- } \\
\text { gion: Vietnam }\end{array}$ & $\begin{array}{l}\text { Taylor } 2019 \\
\text { MULTI }\end{array}$ & $\begin{array}{l}\text { PQ7: 9/89 } \\
\text { PQ14:9/91 }\end{array}$ & 1.03 (0.41 to 2.58$)$ & & $\begin{array}{l}\text { Dak O \& Bu Gia Map: } 1.21 \text { (0.49 to } \\
2.97 \text { ) } \\
\text { Krong Pa: } 0.47 \text { (0.04 to } 5.18 \text { ) }\end{array}$ \\
\hline See Analysis $4.2 \mathrm{fc}$ & k ratio. & & & $\begin{array}{l}\text { Total: } 1.07 \\
(0.84 \text { to } \\
1.37)\end{array}$ & Total HR: 1.17 (0.88 to 1.55 ) \\
\hline
\end{tabular}

aEvents/person-years (or per person-days converted to person-years) reported in study reports for estimation of rate ratios.

bPooled rate ratios were calculated in RevMan 5 (analyses not shown) based on log rate ratios and their SEs using the generic inverse variance method.

CHazard ratios reported by study site in Taylor 2019 MULTI.

3b. Rate ratios for the outcome 'Recurrence' at 3 and 6 months follow-up of the comparison ' $1.0 \mathrm{mg} / \mathrm{kg} / \mathrm{day}$ primaquine for $7 \mathrm{days}$ versus high-standard 14-day regimen'

\begin{tabular}{|c|c|c|c|c|}
\hline Study & Follow-up & Subgroup & Events / person-years & Rate ratio $(95 \% \mathrm{Cl})$ \\
\hline \multirow{4}{*}{$\begin{array}{l}\text { Taylor } 2019 \\
\text { MULTI }\end{array}$} & \multirow[t]{4}{*}{3 months } & Blood-stage drug: chloroquine & PQ7: 35/122 & \multirow[t]{2}{*}{1.36 (0.82 to 2.25$)$} \\
\hline & & & PQ14: 27/128 & \\
\hline & & \multirow[t]{2}{*}{ Blood-stage drug: DHA-PPQ } & PQ7: 7/98 & \multirow[t]{2}{*}{1.37 (0.44 to 4.32$)$} \\
\hline & & & PQ14: 5/96 & \\
\hline
\end{tabular}

See Analysis 4.3 and Analysis 4.4 for risk ratios

Total: 1.36 (0.86 to 2.16$)$

\begin{tabular}{|c|c|c|c|c|}
\hline \multirow[t]{2}{*}{$\begin{array}{l}\text { Taylor } 2019 \\
\text { MULTI }\end{array}$} & 6 months & Blood-stage drug: chloroquine & $\begin{array}{l}\text { PQ7: 53/231 } \\
\text { PQ14: 51/245 }\end{array}$ & 1.10 (0.75 to 1.62$)$ \\
\hline & & Blood-stage drug: DHA-PPQ & $\begin{array}{l}\text { PQ7: 32/193 } \\
\text { PQ14: 19/189 }\end{array}$ & 1.65 (0.94 to 2.91$)$ \\
\hline
\end{tabular}

\section{WHAT' S NEW}

\begin{tabular}{lll}
\hline Date & Event & Description \\
\hline 7 July 2020 & $\begin{array}{l}\text { New citation required and conclusions } \\
\text { have changed }\end{array}$ & $\begin{array}{l}\text { We included two new large important trials using higher dose } \\
\text { for 7 days compared to high standard 14-day course, following a } \\
\text { search update to 2 September 2019. }\end{array}$ \\
\end{tabular}




\begin{tabular}{lll}
\hline Date & Event & Description \\
\hline 7 July 2020 & New search has been performed & We updated the date of search to 2 September 2019. \\
\hline
\end{tabular}

\section{H IST O R Y}

Protocol first published: Issue 5, 2017

Review first published: Issue 7, 2019

\section{CONTRIBUTIONS OF AUTHORS}

Rachael Milligan (RM): data collection and management, analysis and interpretation of results, review writing.

Andre Daher $(A D)$ : data collection and management, analysis and interpretation of results, review writing.

Gemma Villanueva (GV): data collection and management, analysis and interpretation of results, review writing.

Hanna Bergman (HB): data collection and management, analysis and interpretation of results, review writing.

Patricia Graves (PMG): interpretation of results, review writing.

All review authors read and approved the final manuscript.

\section{DECLARATIONS OF INTEREST}

RM has no known conflicts of interest.

$A D$ has no known conflicts of interest.

GV works for Cochrane Response, an evidence services unit operated by the Cochrane Collaboration, and has no known conflicts of interest. Cochrane Response was contracted by the CIDG to update this review.

HB works for Cochrane Response, an evidence services unit operated by the Cochrane Collaboration, and has no known conflicts of interest. Cochrane Response was contracted by the CIDG to update this review.

PMG has no known conflicts of interest.

\section{SOURCES OF SUPPORT}

\section{Internal sources}

- Liverpool School of Tropical Medicine, UK

\section{External sources}

- Department for International Development, UK

Project number 300342-104

\section{DIFFERENCES BETWEEN PROTOCOLAND REVIEW}

We changed the inclusion criteria for trials to add $30 \mathrm{mg}(0.5 \mathrm{mg} / \mathrm{kg} /$ day) for 14 days, as this is a World Health Organization-recommended regimen, and some trials use it as the control group for this reason.

\section{INDEX TERMS}

\section{Medical Subject Headings (MeSH)}

Antimalarials [administration \& dosage] [ ${ }^{*}$ therapeutic use]; Drug Administration Schedule; Malaria, Vivax [ ${ }^{\star}$ drug therapy]; Primaquine [administration \& dosage] [^therapeutic use]; Primary Prevention; Randomized Controlled Trials as Topic; Recurrence

\section{MeSH check words}

Humans 